If you do not need this report after it has served your purpose, please return it to the Geological Survey, using the official mailing label at the end

UNITED STATES DEPARTMENT OF THE INTERIOR

Harold L. Ickes, Secretary

GEOLOGICAL SURVEY

w. C. Mendenhall, Director

Professional Paper 186-F

\title{
AMERICAN CRETACEOUS FERNS OF THE GENUS TEMPSKYA
}

BY

CHARLES B. READ and ROLAND W. BROWN

Shorter contributions to general geology, 1936

(Pages 105-131)

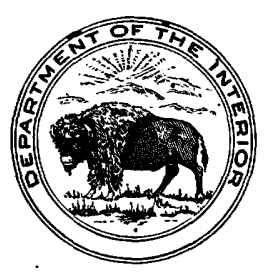

UNITED STATES

GOVERNMENT PRINTING OFFICE

WASHINGTON : 1937 


\section{CONTENTS}

Abstract

Introduction

Historical account. .

Bibliography

Systematic descriptions _. . . .

Tempskyaceae. ............

Genus Tempskya Corda (emend.) _..........

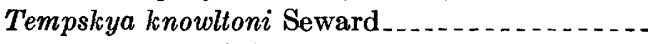

Tempskya grandis Read and Brown, n. sp...--

Tempskya minor Read and Brown, n. sp.......

Tempskya whitei Berry
Page

105

105

106

107

108

108

108

112

114

117

119

Systematic descriptions-Continued.

Tempskyaceae-Continued. Page

Tempskya sp........................... 119

Synopsis_...

Taxonomic position _.......................... 120

Affinities of Tempskya

Interrelationships of the species.............. 122

Probable habit of Tempskya

Stratigraphic significance of the Tempskyaceae. . . . . . 124

Conclusions . . . . . . 129

\section{ILLUSTRATIONS}

Plate 27. Chart showing occurrence of Tempskya.....-

28-43. Species of the genus Tempskya ........

Figure 2. Sketch of a transverse section of Tempskya knowltoni Seward showing the dorsiventral orientation of the stems in the root mass.-

3. Sketch of a transversely cut face of Tempskya grandis Read and Brown, n. sp., showing the radial orientation of the dorsiventral stems in the false trunk . . .
Page

124

131

108
Figure 4. Sketch of Tempskya minor Read and Brown, n. sp., showing the prominently dorsiventral orientation of the stems in the false

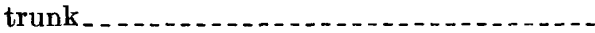

5. Sketches showing in diagrammatic fashion the development of the leaf trace in Tempskya.-

6. Map showing Tempskya localities in ihe United

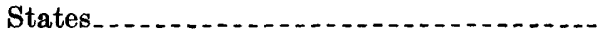

Page

108

109

$\mathbf{n}$ 


\title{
AMERICAN CRETACEOUS FERNS OF THE GENUS TEMPSKYA
}

\author{
By Charles B. Read and Roland W. Brown
}

\begin{abstract}
The Tempskyas are a group of ferns, known at present from remains of stems, leaf bases, and roots found in rocks of Cretaceous age in Europe and North America. They were first recorded in 1824 by Stokes and Webb under the name Endogenites. In 1845 Corda, after examination of similar material from Bohemia, established Tempskya as a genus, and some years later the identity of Stokes and Webb's specimens became known. During the later part of the nineteenth century several investigators, among them Feistmantel, Velenovsky, and Seward, had occasion to deal with the genus. Owing to the very poor preservation of most of the specimens the investigators were not able to recognize the true nature of the materials, although they were admitted to be fern stems. The prevalent opinion was that the structure was similar to that of Protopteris.

In 1911 Kidston and Gwynne-Vaughan published a study of a well-preserved Tempskya from the Ural Mountains and definitely established the fact that in Tempskya the large trunklike mass that is commonly preserved consists of an aggregate of stems bound together by a thick mat of roots into a false trunk.

In America the first record of Tempskya was made in 1911, when Berry described Tempskya whitei from the Patapsco formation (Lower Cretaceous) of Maryland. In 1924 Seward published an account of a very well preserved specimen from what is now known to be the Colorado shale (Upper Cretaceous) near Harlowton, Mont. In that contribution considerable space was devoted to an analysis of habit and affinities, and the conclusion was reached that the false trunk was subterranean, obliquely ascending, and that the plant was of schizaeaceous affinities.
\end{abstract}

The present paper sets forth the generic characters and, after presenting a summary of Tempskya knowltoni Seward, describes Tempskya grandis, Tempskya minor, and Tempskya sp. from strata of Upper Cretaceous age in western Wyoming and adjacent portions of Idaho and Utah. A few observations are made on Tempskya whitei Berry. All these species conform to the generic diagnosis based on Tempskya rossica as regards the dorsiventral stems, the siphonosteles, the two-ranked leaves, and the diarch roots. All have developed the false-trunk habit. It is shown that this false trunk may be dorsiventral or radial in its symmetry and that this symmetry appears to be constant within a species. It is suggested that the radially arranged false trunks must have stood upright and that the dorsiventral false trunk may have been characteristic of lianalike or cliffclimbing ferns, or even of partial epiphytes. False trunks of a similar type are not known among either modern ferns or other groups of fossil ferns.

The problem of the exact affinities of Tempskya is not solver. Tempskya is unquestionably one of the Leptosporangiatae and may be related to any one of several families. A temporary family, the Tempskyaceae, is erected for the genus.

The stratigraphic range of the genus appears to be from lowermost Lower Cretaceous to Senonian. In western America it is apparently restricted to the Colorado group.

\section{INTRODUCTION}

In the annals of paleobotany the genus Tempskya has long occupied a very speculative position. It was reported under the name Endogenites as early as 1824 and elevated to its present status as the genus Tempskya in 1845, but its true nature was not realized until 1911. Since then there has been some progress by way of occasional contributions tending to show the diversification of the genus.. However, several important issues remain to be decided. There are conflicting points of view concerning the habit and taxonomic position of Tempskya among the ferns.

It is the purpose of the writers of this paper to review the genus and the various opinions that have been expressed concerning it. New material from the western United States is described, some of which has a significant bearing on the habits of the genus. Tempskya knowltoni Seward has been redescribed, not because of any fault in Seward's account but because of the desirability of emphasizing the distinctive characters of this fossil by way of contrast in making the specific differentiation of the other materials. Little attempt has been made in the past to discuss the stratigraphic range of Tempskya. The writers have essayed to compile the facts concerning its occurrence in an effort to estimate the value of the several species as age indexes.

The assistance and encouragement of the officials of the United States Geological Survey in the preparation of this report is acknowledged with pleasure. J. B. Reeside, Jr., has been especially interested in the work and has given many valuable suggestions. The late Dr. David White likewise cheerfully contributed advice and constructive criticism. G. R. Mansfield, W. W. Rubey, and J. S. Williams, of the Geological Survey, Prof. G. R. Wieland, of Yale University, and Prof. S. H. Knight, of the University of Wyoming have collected most of the new material during the course of various geologic investigations in southeastern Idaho and adjacent parts of Wyoming. Dr. R. S. Bassler has generously permitted the preparation of several unusually large thin sections in the laboratories of the United States National Museum, and K. J. Murata has prepared most of the excellent sections of the new material here illustrated. 


\section{HISTORICAL ACCOUNT}

The earliest record of Tempskya that the writers have been able to find is an account of Endogenites erosa given by Stokes and Webb ${ }^{1}$ in 1824 in their report on plant material collected in Tilgate Forest by Mantell. As the generic name indicates, the silicified remains were regarded as monocotyledonous forms, possibly palms. In 1832 Cotta $^{2}$ referred similar material to Porosus marginatus and differed with Stokes and Webb in pronouncing the material to be portions of a large fern stem. In the following year this same opinion was expressed by Mantell ${ }^{3}$ after a careful examination of the specimens that he had collected about 10 years before. In 1836 Fitton gave an account of similar materials found near Hastings and referred them to Endogenites erosa.

In 1845 a noteworthy contribution was made by Unger, ${ }^{4}$ who inclined to the opinion that Endogenites erosa was simply a mode of preservation of Protopteris and introduced evidence in support of this idea.

In the same year Corda ${ }^{5}$ published the results of his observations on large collections of petrifications and erected in honor of Tempsky a new genus, Tempskya, for four specimens of silicified material from as many localities, presumably in Bohemia and adjacent regions. The generic diagnosis is as follows:

Truncus * * * Rhachis rotundata, plicata vel alata; cortice crassiuscula, fasciculis vasorum ternatis, majori clauso vel lunulato et supra incurvo, minoribus oppositis lunulatis. Radices minutae numerosissimae; fasciculo vasorum centrali unico.

Tempskya was placed in the Phthoropterides, and the interpretation of the silicified masses was that they were branched petioles sheathed in a thick mat of roots. Four species-Tempskya pulchra, T. macrocaula, T. microrrhiza, and T. schimperi-were described on rather questionable grounds. As the preservation is very poor, this historically important material does not furnish many data of value in the study of other specimens. Corda was apparently unaware of the occurrence of similar fossils in England, for no mention is made of Endogenites erosa.

The first intimation that Tempskya is other than the outer or perhaps distal portion of a tree-fern axis is found in a paper by Schenk. ${ }^{6}$ In his opinion Tempskya was a complete stem of possibly marattiaceous affinities, with numerous vascular bundles sheathed in a parenchymatous and sclerenchymatous groundmass.

\footnotetext{
1 Stokes, Charles, and Webb, P. B., Description of some fossil vegetables of the Tilgate Forest in Sussex: Geol. Soc. London Trans., ser. 2, vol. 1, pp. 421-424, pls. 45-47, 1824

2 Cotta, C. B., Die Dendrolithen, p. 41, pl. 8, figs. 4, 5, 1832

3 Mantell, G. A., The geology of the Southeast of England, p. 236, pl. 1, figs 4, 5, 7, 1833.

- Unger, Franz, Synopsis plantarum fossilium, p. 107, 1845.

5 Corda, A. J., Flora protogaea; Beiträge zur Flora der Vorwelt, p. 81, 1845

6 Schenk, August, Beiträge zur Flora der Vorwelt; IV, Die fossile Flora der nordwestdeutschen Wealdenformation: Palaeontographica, vol. 9, pp. 203-266, pls. 42-43, 1871 .
}

In 1872 Feistmantel $^{7}$ suggested that Tempskya was not a genus but rather a mode of preservation of several distinct types of fern stems. Protopteris sternbergii Corda was suggested as one species that might be correlated with tempskyoid preservation. This opinion is very interesting and seems to have made a profound impression on contemporary investigators, for several papers were soon published in support of this theory. Velenovsky ${ }^{8}$ accepted this view and produced new evidence which seemed to corroborate this interpretation.

A very valuable account of the literature on Tempskya is given by Seward in his catalog of Wealden plants. ${ }^{9}$ Feistmantel's ideas were questioned but not definitely discarded. Seward's general conclusions are as follows:

In Tempskya schimperi we have masses of branched diarch fern roots associated with petiole axes, which occasionally afford evidence of branching; probably some forms of Tempskya and Protopteris are very closely related, if not identical plants; but, so far as English specimens are concerned, there is an absence of any direct proof of such organic connection between the two fossils, as Feistmantel and Velenovsky have previously suggested.

In 1897 Stenzel ${ }^{10}$ discussed the question at length and decided that the morphologic make-up of the fossils did not entirely justify any conclusion so far reached as to their exact nature. He offered several possible explanations:

1. Lateral organs of a tree fern growing downward and encased in downward-growing roots. (This hypothesis is similar to that suggested by Corda, although not identical with it.)

2. Independent stems climbing upward between roots.

3. Upward-growing and branching fern stems encased in their own downward-growing roots.

Of these explanations Stenzel inclined toward the last, although he preferred to leave the question open and did not finally commit himself.

It remained for Kidston and Gwynne-Vaughan to determine definitely the exact nature of Tempskya, which they did in an excellent account ${ }^{11}$ of Tempskya rossica, a new species described from the basin of the Karaganda River in Russia. Unfortunately the geologic age of the material is uncertain, because it seems to have been reworked from older strata into a conglomerate of Tertiary age. It must be borne in mind that before the discovery of $T$. rossica all the specimens known were poorly preserved and did not permit detailed examination of the tissues. In the type of T. rossica the preservation is excellent, and as a result

\footnotetext{
7 Feistmantel, Ottokar, Über Baumfarrenreste der böhmischen SteinkohlenPerm- und Kreideformation: K. böhm. Gesell. Wiss. Abh., Folge 6, Band 6, p. 22 , 1872.

8 Velenovsky, Josef, Die Farne der böhmischen Kreideformation: K. böhm. Gesell. Wiss. Abh., Folge 7, Band 2, Nr. 8, p. 25, 1888

${ }^{9}$ Seward, A. C., The Wealden fiora, part 1; Catalogue of the Mesozoic plants in the Department of Geology, British Museum (Natural Histery), pp. 148-159, '1894. 10 Stenzel, K. G., Verkieselte Farne von Kamenz in Sachsen: K. min. Mus. Dresden Mitt., Heft 13, p. 3, 1897.

1t Kidston, Robert, and Gwynne-Vaughan, D. T., On a new species of Tempskya from Russia: Russ. k. min. Gesell. Verh., Band 48, pp. 1-20, pls. 1-3, 1911.
} 
the investigators were able to clear up many unsettled points. They finally concluded that the siliceous masses were false stems - that is, composed of a single dichotomously branching stem system encased in a thick mat of adventitious roots. The stems were highly sclerenchymatous, solenostelic, and dorsiventral. The roots were diarch. As regards the habit, the false stems were suspected of having stood erect to a height of several feet and of having produced a crown of leaves. The affinities of Tempskya were left unsettled, although it was held that they were with the Leptosporangiatae.

In the same year Berry ${ }^{12}$ described an American species, Tempskya whitei, from the Patapsco (Lower Cretaceous) deposits of the Atlantic Coastal Plain. The preservation is poor, however, and no additions to the anatomical knowledge of the genus were made.

Stopes, ${ }^{13}$ in her discussion of the Lower Greensand plants of Great Britain, presented a summary of the progress in the study of Tempskya and redescribed Tempskya erosa Stokes, Webb, and Mantell. A reconstruction of the probable aspect of Tempskya rossica Kidston and Gwynne-Vaughan was included and shows a massive erect false stem bearing a terminal cluster of leaves.

In $1924{ }^{14}$ Seward described a very well preserved Tempskya from Montana. This fossil had been collected by A. C. Silberling in 1908 in the Musselshell Valley and had been in the collections of the United States Geological Survey for a number of years. Dr. Knowlton's activities had been so intensively directed in other fields that he had never been able to investigate it and finally transmitted the complete specimen to Seward. The species was named Tempskya knowltoni and is of Colorado age. It presents several interesting features, among which is an apparent dorsiventrality of the entire false stem. This caused Seward to conclude that $T$. knowltoni was "a root-encircled bundle of stems, obconical and tapering, lying obliquely in the soil, a few of the stem branches bearing crowded fronds near the ground level." The affinities of Tempskya were held to be with the Schizaeaceae, in view of the stelar similarities, the similarity of certain spores found by Boodle in an English specimen to those of schizaeaceous ferns, and finally the alleged similarity of certain sporangia found in the root mat of $T$. knowltoni to the type of sporangia characteristic of the Schizaeaceae.

\section{BIBLIOGRAPHY}

The following list gives the publications that contain descriptions and discussions of the genus Tempskya and its several species.

\footnotetext{
${ }_{12}$ Berry, E. W., Maryland Geol. Survey, Lower Cretaceous, p. 298, pIs. 37, 38, 1911. 13 Stopes, M. C., The Cretaceous flora, part 2, Lower Greensand (Aptian) plant of Britain: Catalogue of Mesozoic plants in the British Museum (Natural History) pp. 9-21, text flgs. 2-5, 1915.

14 Seward, A. C., On a new species of Tempskya frorn Montana, Tempskya knowttoni, sp. nov.: A nnals of Botany, vol.38, no. 151, pp. 485-507, text figs. 1-3, pls. 16, 17, 1924
}

Berry, E. W., Maryland Geol. Survey, Lower Cretaceous, pp. 295-299, pls. 37, 38, 1911.

Boodle, L. A., Spores in a specimen of Tempskya (Endogenites): Annals of Botany, vol. 9, pp. 137-141, text figs. 1-4, 1895. Bower, F. A., The ferns, vol. 2, pp. 106, 169, 1926.

Brongniart, Adolphe, Tableau des genres de végétaux fossiles, p. 107,1849

Bronn, H. G., Index paleontologicus nomenclator, vol. 1, p. 461, 1848.

Bronn, H. G., and Roemer, Ferdinand, Lethaea geognostica, vol. 2, p. 46 , pl. 28, fig. 8a, b, c, 1851.

Carpentier, Alfred, La flore wealdienne de Feron-Glageon (Nord): Soc. géol. Nord Mém., vol. 10, 1927.

Corda, A. J., Flora protogaea; Beiträge zur Flora der Vorwelt, pp. $81-83,1845$.

Cotta, C. B., Die Dendrolithen, pp. 37-44, pl. 8, figs. 4, 5, 1832.

Dixon, Frederick, Geology of Sussex, 2d ed., p. 282, 1878.

Dunker, Wilhelm, Monographie der norddeutschen Wealdenbildung, p. 17, p]. 3, figs. 1, 1a, 1b, 1846.

Engler, Adolf, and Prantl, K. A. E., Die natürlichen Pflanzenfamilien, Teil 1, Abt. 4, p. 512, 1902.

Ettingshausen, Constantin von, Beitrag zur näheren K€nntniss der Flora der Wealden Periode: K.-k. geol. Reichsanstalt Abh., vol. 1, pt. 2, no. 2, p. 19, 1852.

Feistmantel, Ottokar, U̇ber Baumfarrenreste der böhmischen Steinkohlen-, Perm- und Kreideformation: K. böhm. Gesell. Wiss. Abh., Folge 6, Band 6, p. 22, 1872.

Fitton, W. H., Observations on some of the strata between the Chalk and Oxford oolite in the Southeast of England: Geol. Soc. London Trans., ser. 2, vol. 4, p. 172, pls. 19, 20, text fig. 1, 1836

Giebel, C. G., Deutschlands Petrefacten: Fossile Pflanzen, vol. 1, p. 66,1852 .

Gutbier, August von, Die Versteinerungen des Rothliegenden in Sachsen, p. 17, 1849.

Gwynne-Vaughan, D. T. See Kidston, Robert.

Hirmer, Max, Handbuch der Paläobotanik, p. 681, 1927.

Hosius, August, and Marck, W. von der, Die Flora der westfälischen Kreideformation: Palaeontographica, vol. 26, p. 192 (68), pl. 39, figs. 161-163, 1880.

Kidston, Robert, and Gwynne-Vaughan, D. T., On the fossil genus Tempskya: British Assoc. Adv. Sci. Rept., Sheffield, p. $783,1910$.

Kidston, Robert, and Gwynne-Vaughan, D. T., On a new species of Tempskya from Russia: Russ. k. min. Gesell. Verh., Band 48, pp. 1-20, pls. 1-3, 1911.

Knowlton, F. H., Plants of the past, pp. 143-146, text fig. 67, 1927.

Mantell, G. A., Illustrations of the geology of Sussex; Fossils of the South Downs, p. 42, 1822.

Mantell, G. A., in Stokes, Charles, and Webb, P. B., Description of some fossil vegetables of the Tilgate Forest in Sussex: Geol. Soc. London Trans., ser. 2, vol. 1, p. 423, pl. 46, figs. 1,2 ; pl. 47 , figs. 5 a, b, 1824 . (No author's name given.)

Mantell, G. A., Illustrations of the geology of Sussex; Fossils of the Tilgate Forest, p. 54, pl. 3, figs. 1, 2; pl. 3 [so numbered in the book], fig. 5, 1827.

Mantell, G. A., The geology of the Southeast of England, p. 236 , pl. 1, figs. 4, 5, 7, 1833 .

Martin, P. I., A geological memoir on a part of western Sussex, p. $41,1828$.

Morris, John, A catalog of British fossils, 2d ed., p. 8, 1854

Reuss, A. E., Die Versteinerungen der böhmischen Kreideformation, p. 87 , pl. 47 , fig. 7, 1845-46.

Schenk, August, Beiträge zur Flora der Vorwelt; IV, Die fossile Flora der nordwestdeutschen Wealdenformation: Palaeontographica, vol. 19, p. 259, pl. 42, fig. 4; pl. 43, 1871.

Schimper, W. P., Traité de paléontologie végétale, vol. 1, p. $698,1869$. 
Seward, A. C., The Wealden flora, Part I: Catalogue of the Mesozoic plants in the Department of Geology, British Museum (Natural History), pp. 148-159, 1894.

Seward, A. C., On a new species of Tempskya from Montana, Tempskya knowltoni, sp. nov.: Annals of Botany, vol. 38, no. 151, pp. 485-507, text figs. 1-3, pls. 16, 17, 1924.

Stokes, Charles, and Webb, P. B., 1824. See Mantell, G. A., 1824.

Stopes, M. C., The Cretaceous flora; Part II, Lower Greensand (Aptian) plants of Britain: Catalogue of the Mesozoic plants in the British Museum (Natural History), pp. 9-21, text figs. 2-5, 1915.

Unger, Franz, Synopsis plantarum fossilium, p. 107, 1845.

Unger, Franz, Genera et species plantarum fossilium, p. 201, 1850.

Velenovsky, Josef, Die Farne der böhmischen Kreideformation: K. böhm. Gesell. Wiss. Abh., Folge 7, Band 2, p. 23, 1888.

\section{SYSTEMATIC DESCRIPTIONS}

\section{TEMPSKYACEAE 15}

Genus TEMPSKYA Corda (emend.)

1845. Corda, A. J., Flora protogaea; Beiträge zur Flora der Vorwelt, p. 81.

1911. Kidston, Robert, and Gwynne-Vaughan, D. T., On a new species of Tempskya from Russia: Russ. k. min. Gesell. Verh., Band 48, pp. 1-20, pls. 1-3.

The generic diagnosis given by Kidston and GwynneVaughan is as follows:

Stems of small diameter, erect, dichotomous, and embedded in a felted mass of their own adventitious roots. Dorsiventral, with the leaves in two rows on one side of the stem and roots alone on the opposite side. Vascular system of stem a solenostele. Leaf trace departs as a single strand. Roots diarch. ${ }^{16}$

In Corda's account ${ }^{17}$ of Tempskya four speciesTempskya pulchra, T. macrocaula, T. microrrhiza, and T. schimperi-are described in the order named. According to strict botanic nomenclature one of these, preferably the first, should be designated as the genotype. The writers, although they heartily approve of the several codes of rules followed by systematists, think it is desirable here to depart from their general practice and recommend that Tempskya rossica Kidston and Gwynne-Vaughan be admitted as the type of the genus. The reasons are several. In the first place, T. pulchra, the first species named by Corda, is very

- imperfectly known and has not been carefully investigated, to the writers' knowledge, since Corda's publication. The same is true of his other three species. Furthermore, the preservation of the material, if several later accounts are correct, is very mediocre, so that many of the details are lost and specific differentiation is questionable. On the other hand, T. rossica is a beautifully preserved fossil and has been carefully studied by two very distinguished investigators of plant morphology. In consequence a wealth of detail has been recorded. Therefore, T. pulchra Corda at best

15 See p. 122

16 Kidston, Robert, and Gwynne-Vaughan, D. T., op. cit., p. 13, 1311.

17 Corda, A. J., op. cit., pp. 81-82, 1845. can be recognized as no more than a nominal genotpye, and T. rossica must be taken as the "working" type.

Gross aspect of Tempskya.-As viewed with the naked eye or under a low-power hand lens, specimens of

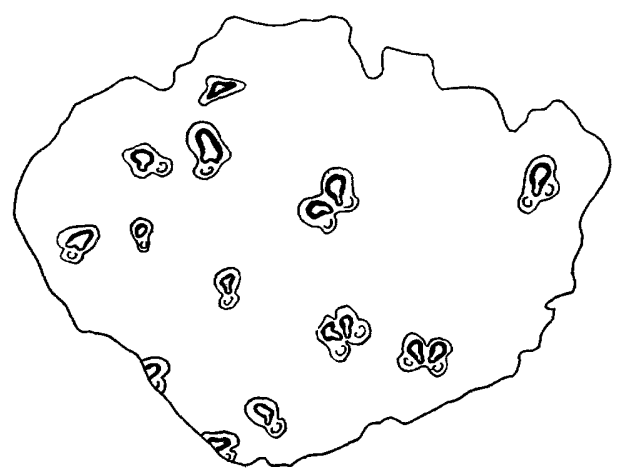

FraURE 2.-Sketch of a transverse section of Tempskya knowltoni Seward showing the dorsiventral orientation of the stems in the root mass.

Tempskya bear a striking similarity to fragments of palm stem. Plate 28, figures 1 and 2, and plate 29,

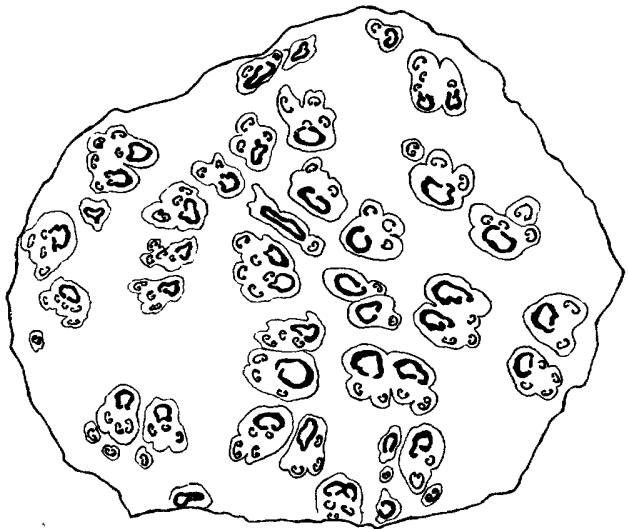

Figure 3.-Sketch of a transversely cut face of Tempskya grandis Read and Brown, n. sp., showing the radial orientation of the dorsiventral stems in the false trunk. U. S. Nat. Mus. 39267. Half natural size.

figures 1 and 2, convey some idea of the general aspect of transverse faces of the "false stem" with a magni-

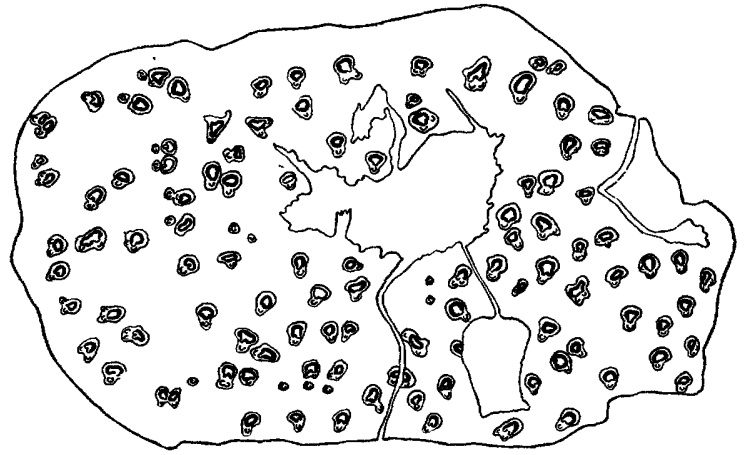

FIGURE 4.-Sketch of Tempskya minor Read and Brown, n. sp., showing the predoninantly dorsiventral orientation of the stems in the false trunk. U. S. Nat. Mus. 39259. Half natural size.

fication of a few diameters. There is a groundmass of small organs, round or elliptic in cross section that suggest the scattered collateral vascular bundles of a palm trunk, and embedded in this mass are a few 
larger and more irregularly shaped organs that suggest the adventitious roots so commonly found in the outer region of the basal portion of the stem of an arborescent monocotyledon. The former are adventitious diarch roots; the latter are stems embedded in this felted root mass, and the whole forms what is termed a false stem. which is sketched from a section of Tempskya knowltoni Seward, indicates that there is apparently a strong dorsiventrality in the false stem-that is, the stems are so oriented that their leaf traces pass off in approximately the same direction throughout the false stem. Another diagram of the arrangement of stems within

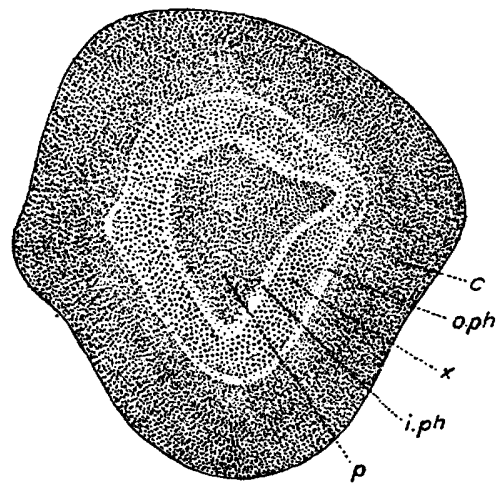

$\alpha$

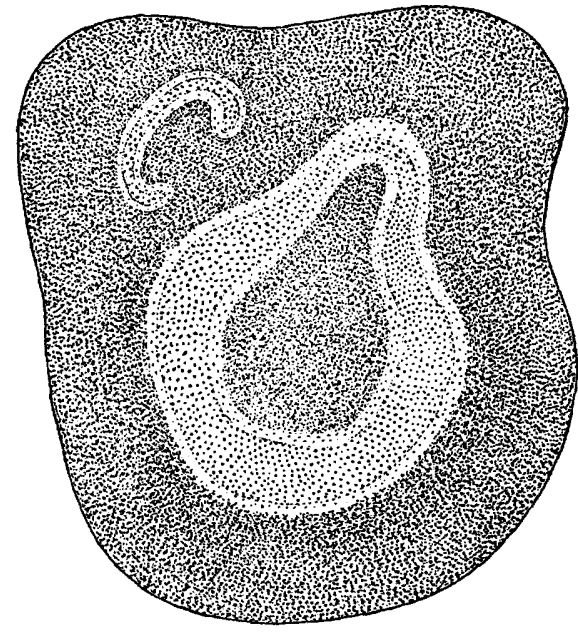

b

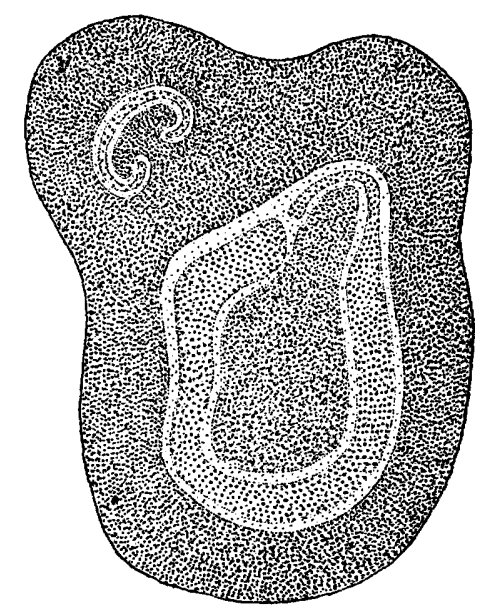

C

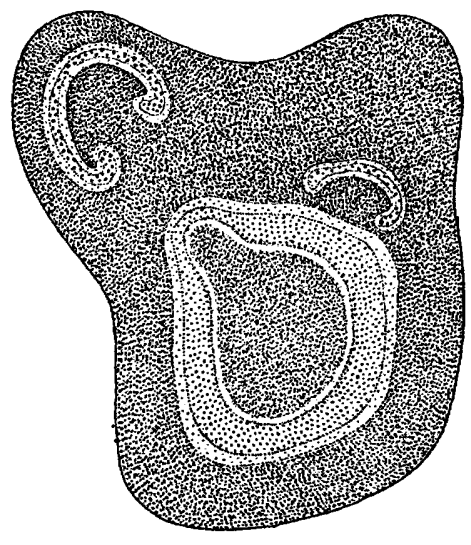

$\alpha$

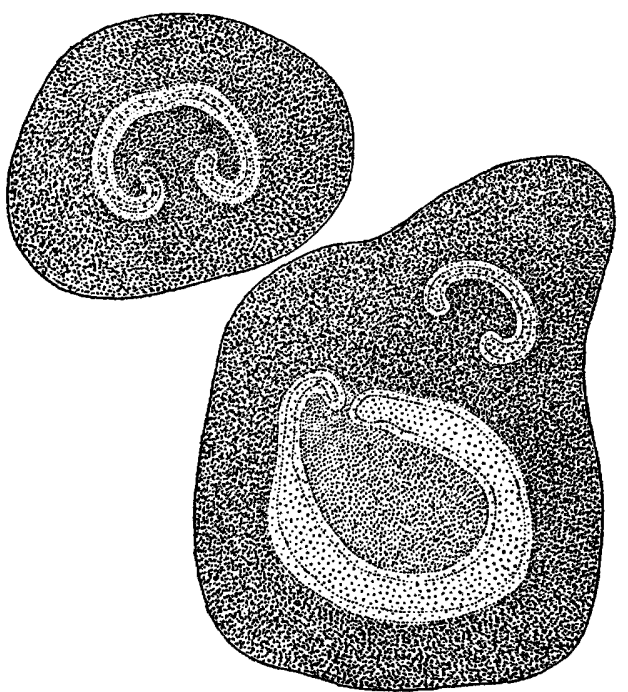

e

forming and terminal portions of left trace showing a tendency to recurve. $d$, Right trace has just passed into the inner cortex, the gap having closed behind it, and left trace has become still more recurved. e, Left trace has passed into the base of the phyllopodium, whereas the right trace is gradually emerging in the cortex. Enlarged about 10 diameters.
FigURe 5.-Sketches showing in diagrammatic fashion the development of the lea trace in Tempskya. a, A stem just prior to the gapping by an emerging leaf trace, which is shown in the upper right portion of the stele $(p$, pith; $i . p h$, internal phloem, pericycle, and endodermis; $x$, xylem; o. ph, external phloem, pericycle, and endodermis; $c$, cortex). $b$, Leaf trace forming a distinct bulge outward from the main axis. To the left is another trace in the cortex. c, Gap of right trace just

The stems, as has been previously demonstrated ${ }^{18}$ and as is again shown in this paper, are dorsiventral and appear to be a much-branched axial system of a single plant rather than a number of individuals of gregarious disposition. It follows, therefore, that a survey of the orientation of the individual stems may furnish information of great value for the determination of the habit of the plant. Text figures 2 to 4 have been prepared to demonstrate this plainly. Text figure 2,

\footnotetext{
18 Kidston, Robert, and Gwynne-Vaughan, D. T., op. cit., 1911.
}

the groundmass of roots is seen in text figure 4, which is drawn from the specimen that is described on page 117 as T. minor, a new species. A similar dorsiventral arrangement, is at once manifest. Figure 3 shows the condition in $T$. grandis, another new species. A striking lack of sinilarity to $T$. knowltoni, so far as the orientation of the stems is concerned, is at once apparent. The symmetry of the dorsiventral stems is radial within the false stem-that is to say, the leaf traces are regularly directed toward the nearest point 
on the periphery. T. rossica Kidston and GwynneVaughan shows symmetry perhaps intermediate between radial and dorsiventral.

In conclusion, two conditions prevail in the genus Tempskya, so far as the orientation of the dorsiventral stems within the false stem is concerned-an apparently well-established dorsiventral arrangement in some species and an apparent radial arrangement in other species. Transitional forms may occur as well. The bearing of these facts on the probable habit of Tempskya is discussed elsewhere (pp. 122-124).

Branching of the stem.-The numerous thin sections that have been prepared from the several species of Tempskya show that frequent dichotomy of the stem is characteristic of the genus as a whole. That the forks of this dichotomy are equal in size is obvious from plate 29, figure 3 . No suggestion of lateral branching has been observed. The writers attempted to determine the distance between these successive bifurcations by cutting a block several inches long into serial sections, but they found that this character is so variable that it has little value either for morphologic or for taxonomic considerations.

Disposition of the tissues in the stem.-The stem of Tempskya is characterized by a siphonostele, as is clearly shown in plate 30 , figure 1 , and plate 31 , figures 1 and 2 . The periphery of the stem is a layer a few cells thick of only slightly modified parenchyma and constitutes what may be termed the outer cortex. The epidermis, in the individuals that the writers have observed, is in a very poor state of preservation and rarely furnishes information relative to emergences which might be of systematic value. Beneath this thin outer cortex is a rather thick zone of highly sclerenchymatous tissue, which in many specimens makes up the bulk of the cortex. This tissue is here referred to as the middle or sclerenchymatous cortex. The cells that make up this tissue are isodiametric in cross section, their lumens are minute and commonly appear to have been congested with some gummy material, and when viewed in longitudinal section they are elongate. They are typical fibrous elements similar to those which may be observed in the mechanical tissue of the bracken fern or in the so-called "bast" of the higher plants.

Within the zone of sclerenchyma there is a variable but generally thin zone of inner parenchymatous cortex. In Tempskya rossica, T. knowltoni, and T. minor this layer is so homogeneous that it does not merit a detailed description. In $T$. grandis, however, the inner cortex is more complex. There the zone is rather broad, sometimes rivaling the sclerenchymatous sheath in breadth. The bulk of the tissue is large-celled parenchyma, but near the inner margin there is an irregular layer of sclerotic tissue (pl. 34, fig. 4). Isolated strands of this tissue also occur. Within is a narrow zone of parenchyma bordering the endodermis.
The width of this inner cortex is a character of considerable value in taxonomic work on the genus, and obviously the varying complexity, as typified on the one hand by Tempskya knowltoni and on the other by $T$. grandis, is of specific worth.

The cortical tissues are limited internally by an endodermis, which is seldom distinctly seen for any considerable distance, perhaps because of faulty preservation. In Tempskya knowltoni Seward it is not usually observed, but in one species that is described in this paper it is a fairly definite layer and is of the type found in the leptosporangiate Filicales.

The pericycle, which is developed below the endodermis, is a tissue of parenchymatous nature and variable thickness. It is usually thin (only two or three cells in thickness), although in some individuals it seems to be slightly thicker. Its inner limit cannot be determined exactly, for in many specimens it cannot be definitely delimited from the phloem. Plate 34, figure 3 , illustrates this feature fairly well.

The phloem is rather indefinite so far as its limits are concerned. Its morphologic identity cannot always be determined with exactitude, but one of the writers has observed the remains of poorly preserved sieve plates, so there seems to be no doubt that it actually exists as a well-organized tissue. There appears to be a thin zone of larger parenchymatous cells on the inner face of the phloem, which may possibly be regarded as ground parenchyma occupying a position between the phloem and xylem. This has not finally been determined but is quite within the range of probability.

The xylem ring, which is the most conspicuous feature of the stele, is from 5 to about 15 cells in thickness. For the sake of convenience, the xylem may be divided into an outer limiting region of very small elements and an inner region of larger elements. The outer limiting region of the xylem may be best described as problematical protoxylem. It may form a rather continuous layer, as is seen in plate 30 , figure 1 , or it may be somewhat scattered, as in plate 34 , figure 4 . In the writers' opinion this zone must be regarded as an exarch protoxylem, and in Tempskya grandis the protoxylem may vary from exarch to slightly mesarch. They are unable, however, to produce any evidence of spiral or annular thickenings on the walls of the elements. Such a condition is not without parallel in the Leptosporangiateae-the Schizaeaceae, for instance, being without any typical protoxylem. Also it is stressed that the siliceous constitution of all of the material seems to be unfavorable to the preservation of such delicate structures as the thickenings on the walls of the protoxylem, even though they were originally present.

The inner region of the xylem presents nothing out of the ordinary. The tracheids are of the scalariform type so common in the Filicales. One feature of note, which the writers stress in the specific differentiation 
attempted in another part of this paper, is the variation in the amount of parenchyma diffused through the xylem. In Tempskya knowltoni Seward there is very little xylem parenchyma, but in one of the species collected from the Aspen shale of Wyoming parenchyma is abundant. This variation is seen at once by comparing plate 31 , figures 1 and 2 , with plate 34 , figures 3 and 4.

The xylem ring is continuous except in the region immediately subtended by a departing leaf trace and varies little in thickness except at such points. A discussion of the origin of these lateral organs is given below.

Internal to the xylem there is present a thin layer of parenchymatous tissue limited by an inner endodermis. This parenchyma includes both phloem, pericycle, and the layer of thin-walled cells between the xylem and phloem and is in all respects similar to the comparable tissues that enclose the xylem.

The pith is sclerotic in all specimens. Just below the endodermis there may be in some places a narrow zone of parenchymatous tissue, but by far the greater portion of the central area is occupied by sclerenchymatous tissue quite similar to that found in the middle cortex.

Leaf trace.-The stelar ring is, except in the region where leaf traces are given off, rather regular in thickness. On the upper side of the stem there are, however, in almost every section, indications of departure or preparation for departure of one or more traces to the lateral appendages. The situation that exists at the point of origin of a trace is, first of all, a thinning of the xylem ring in the immediate vicinity of the portion that is destined to pass out. At the same time this portion of the stele tends to arch outward, approaching gradually the state shown in text figure $5, a$, and in plate 31 , figure 1 . The xylem and other stelar tissues thin still more and at the same time bulge outward (text fig. $5, b$ ). It must be borne in mind that the leaves are two-ranked on the upper surface, and a plane of bilateral symmetry lies between the two rows of appendages. Gradually the stele is broken, first on the side nearest this plane of bilateral symmetry, as is shown in text figure $5, c$, and also in plate 31 , figure 2 . Immediately the internal and external phloem as well as the other tissues enclosed by the endodermis pass around the free ends of the xylem and become continuous. At the same time there is established a connection between the sclerotic and parenchymatous tissues of the middle and inner cortex and the similar tissues of the pith. This is well shown in plate 31 , figure 2 , as well as in text figure $5, e$. The hook-shaped xylem rapidly becomes more highly arched and finally detached inferiorly to assume a curved form similar to that shown in text figure $5, d$. This trace consists of an inner and outer phloem, pericycle, and endodermis with a centrally disposed band of xylem. At first the trace is rather broadly U-shaped with the extremities facing directly inward. Gradually as the trace traverses the cortex on its obliquely ascending course these extremities fold inward until the very characteristic form of the free petiole or phyllopodium is assumed. This is shown in plate 42 , figures $1-3$ and 5 , and in text figure $5, d$ and $e$. The gap formed by the leaf trace is very short, closing up almost immediately after the superior terminus of the trace becomes free from the main stele. The course of the traces, as has been previously suggested, is nearly parallel to that of the stem, so that a section cut transversely across the stem is very nearly a transverse section of the leaf trace. In the outer portion of the cortex and in the free and nearly free petioles such sections indicate that the vascular strand flexes to pass outward more rapidly.

The course of the protoxylem is very difficult to follow because it is not well differentiated. According to the writers' understanding, the leaf bundle is triarchendarch. A careful study of numerous leaf traces has shown that on the inner (concave) side of each lateral termination of the leaf trace there is a cluster of small cells which has all the aspects of protoxylem. A third lies at the bottom of the concavity.

The length of the internode varies considerably within the genus. Plate 29, figure 3 , and plate 32 , figures $2-5$, convey some idea of the extremes.

Phyllopodium.-The term "phyllopodium" as here used refers to the axial system of those lateral appendages of the stem commonly referred to as leaves-that is, it applies to the petiole and rachis and the branches of those organs. In all except one of the species that have been studied only the bases of the phyllopodia are commonly present. This fact is rather noteworthy, and its full significance is discussed in the descriptions of species. Here it is sufficient to point out that usually an abscission layer was early developed and resulted in the occurrence of attached leaves only at the apex of the false stem. The exception is Tempskya minor, where rachides are common in the groundmass of the false stem. Serial sections of several specimens have shown that these are attached to the axes. Some of these stems have been penetrated by adventitious roots, an indication of old age. It therefore seems most likely that in this species the leaves were persistent for a considerable time.

The vascular system at the base of the phyllopodium is similar to that of the leaf trace. There is a progressive thinning and at the same time a lengthening of the xylem strand, so that at its actual emergence from the stem it is but one to three tracheids wide except at the swollen terminals and includes a rather large area of sclerotic cells within the arch. (See pl.42, fig. 1.) The most striking feature, however, is the decidedly involute position of the terminal portions of the strand as seen in plate 42 , figure 1 . There is a tendency for these points to curl inward as the leaf trace approaches 
the periphery of the stem. At the base of the phyllopodium this is very marked and simulates the completely closed, pseudoaxial stele of the petiole of Gleichenia pectinata.

The problematical parenchyma sheath, phloem, pericycle, and endodermis completely encircle the xylem. These tissues are similar to those that enclose the xylem in the main axis and so do not merit further discussion except to point out that they diminish in areal extent in the phyllopodium so as to retain appropriate proportions with the xylem.

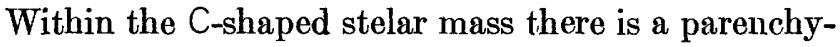
matous sheath of slight extent bordering the endodermis and flanked inwardly by a mass of sclerenchyma similar to that observed in the pith of the stem. Both the parenchymatous sheath and the sclerenchymatous tissue are in direct connection with similar areas external to the vascular strand-that is, there is a similar zone of thin-celled tissue on the adaxial side of the stele in direct connection around the extremities of the vascular bundle, and external to this there is a hypodermal layer of considerable extent of sclerotic tissue also in connection with the similar tissue within the $C$. The whole mass is enclosed by a narrow zone of parenchyma, usually showing poor preservation and limited by an epidermis equally poor in preservation.

Dermal emergences are occasionally preserved in the species described as Tempskya minor. These are unbranched hairs several cells long and but one cell wide. They are particularly abundant in the younger parts of the stems, as is shown in plate 39, figures 1 and 2 . Similar appendages are seen in transverse section in plate 38, figure 1. Apparently these dermal hairs are soon lost, as sections cut through mature stems show little indication of such organs. Of course, the remains of these hairs may become quickly obliterated because of their small size. Furthermore, a search for them is particularly difficult on account of the great quantity of heterogeneous materials that compose the false stem.

Root.-The adventitious roots that form the closely felted mat around the stems are without exception diarch. As seen in plate 29, figure 3, they vary considerably in size, probably in part because of their distance from the point of origin and in part because of the branching. The stele is rather large and consists of two to four centrally disposed large tracheids grouped in an irregular line at right angles to the plane of the protoxylem. Laterally the tracheids very rapidly decrease in size to the first-formed elements, which consist of two to three cells located at the poles. A thin zone of sheathing parenchyma encircles the xylem, becoming continuous with the pericycle at the protoxylem points. The protophloem is located principally in a plane at right angles to the protoxylem and is as poorly differentiated as similar tissue in the stems. The pericycle is well developed and shows no note- worthy differences from that in the stems. A welldefined endodermis delimits the stele, showing at some points poorly preserved Caspary bands on the radial walls.

The cortex consists of a parenchymatous inner layer followed by a thick zone of sclerenchyma. On the exterior of this zone there is seen, in well-preserved specimens, a layer of large-celled parenchyma. Usually this zone shows a marked tendency to become lacunar through the breaking down of some of the tissue. The situation is illustrated in plate 40 . Sheathing this lacunar layer are smaller, thicker-walled cells of the subepidermis and epidermis. Not uncommonly in well-preserved masses of roots there may be observed remarkably well preserved root hairs, which are, like those of modern plants, simple outgrowths from the epidermis. They are remarkable in Tempskya only because of the perfection of preservation of these delicate structures. They may, in fact, be taken as evidence of extremely rapid silicification of the material.

As regards the origin of the root, the first indication of the development of such an organ is reflected in a slight outward bulge in the pericycle. The vascular elements appear to grow out at a variable angle until they reach the middle cortex, where the root flexes directly outward. At the same time there is developed on the xylem ring of the stem a small protuberance of tracheids which appear to unite gradually with those of the root.

\section{Tempskya knowltoni Seward}

Plate 28, figures 1-3; plate 29, figure 3 ; plate 30 , figures 1,2 ; plate 31 , figures 1,2 ; plate 32 , figure 1 ; plate 42 , figure 4 ; plate 43 , figures 2,3 .

1924. Tempskya knowltoni Seward, Annals of Botany, vol. 38, no. 151 , pp. 485-507, pls. $16,17$.

Gross aspect.--The type specimen of Tempskya knowltoni, which has been reported by Seward, is a slightly curved tapering specimen about 33 centimeters long. In cross section the false stem is oval, as shown in plate 28, figures 1 and 2, owing possibly to compression. At the larger and presumably distal end the greater diameter is about 6 centimeters; at the smaller and proximal end, 2 centimeters. The surface is considerably weathered and gives to the specimen a rather nondescript appearance not unlike that of a half-decayed fragment of a palm stem, inasmuch as the numerous roots simulate the scattered bundles of a monocotyledon. Thin slices cut from the specimen show a very excellent preservation. Plate 28, figures 1 and 2, show the general aspect of T. knowltoni in transverse section. The stems, which are numerous, are sheathed in a dense felt of their own adventitious roots. It will be noted that several stems are cut at stages of dichotomy, which in this species was apparently equal.

Photographs of portions of thin sections of Tempskya knowltoni taken at a somewhat higher magnification 
are shown in plate 28 , figure 3 , and plate 29 , figure 3 . The occurrence of the stems in the groundmass of roots is well shown. Most of the roots roughly parallel the stems in their course, but some of them deviate to run obliquely. One very characteristic feature of the siphonostelic stems is well brought out in these photographs-the very dense and thick sclerotic cortex. In both figures numerous roots invade the stelar tissues. This likewise is rather significant and is carefully considered on page 123 .

Anatomy of the stem.-Plate 31, figure 1, illustrates the general aspect of the stem at a magnification of about 40 diameters. The division of the cortex into three distinct regions is clearly shown. On the outside is seen a large-celled parenchymatous tissue that shows a tendency to slough and shred. This zone is only. a few cells thick. Within is a very thick zone of sclerenchyma that shows a dense black on the photograph. This region of fibrous tissue is exceptionally developed in Tempskya knowltoni and furnishes one criterion for its specific separation. The inner cortex is rarely well preserved in this species. It is, however, shown at points and is parenchymatous and from 6 to 11 cells in thickness.

The endodermis is poorly defined in the species, owing possibly to faulty preservation. At any rate it can be recognized at only a few points but is probably a layer a single cell in thickness bounding the cortex. Within lie the pericycle, phloem, and sheathing parenchyma, all poorly preserved but definite at various points on most stems.

The xylem ring, as is shown in plate 30 , figure 1 , and plate 31 , figures 1 and 2 , is from 4 to 15 cells in thickness. It is composed almost entirely of scalariform tracheids with almost no xylem parenchyma. On the exterior of the ring there is an almost continuous layer of very small lumened tracheids. Superficially these suggest protoxylem and in fact are probably best regarded as such, despite the fact that they are scalariform rather than spiral. It may be assumed, temporarily at least, that the protoxylem is exarch and not well differentiated. Such a condition is not without parallel in extant ferns, among which the Schizaeaceae and some other Leptosporangiatae show a similar structure.

Within the xylem ring there is a repetition on a slightly smaller scale of the sheathing parenchyma, phloem, and pericycle investing the cylinder. This zone is bounded by an internal endodermis also vaguely marked.

The central area of the stem consists of an outer thinwalled zone, already described and similar to the inner cortex in general appearance and extent, which encloses an area of very thick-walled, small-lumened sclerenchymatous tissue.

Leaf trace.-The numerous sections of stems of Tempskya knowltoni furnish a very complete series of stages bearing on the origin and development of the leaf trace. The first indication of an emerging strand destined to pass into a phyllopodium is a thinning of the whole stele in a small area in the upper half of the stem. The position of this point is usually to the side of the medial plane. Accompanying this decrease of a part of the stele there is a flexing outward of the area, as seen in plate 31 , figure 1 . This protrusion rapidly increases until first the xylem strand and finally the phloem, pericycle, and endodermis are interrupted on the upper side of the bulge, as is shown in the stem to the left in plate 31 , figure 2 . The outer and inner phloem, pericycle, and endodermis immediately close around this interruption both on the side of the leaf trace and of the parent stele. The figures show that a portion of the pith passes outward within the inverted $U$-shaped meristele. Shortly after the parting of the termination of the trace on the upper side-that is, the one proximal to the median plane-the lower termination separates in a similar manner. The result is the formation of a broad and shallow U-shaped trace with the two ends facing inward toward the foliar gap (pl. 31 , fig. 2). This trace consists of a thin strand of xylem thickening toward the extremities, where the protoxylem appears to lie on the inner side. Phloem, pericycle, and endodermis completely enclose the xylem but form a thicker zone on the convex side of the $U$ than. in the concavity. The mass of sclerenchymatous pith that followed the leaf trace out and occupied the space within the $U$ becomes continuous with the similar tissue of the cortex as soon as the trace penetrates this tissue.

The course of the trace through the cortex is nearly parallel to the parent stele. During this gradual emergence there is a curving inward of the edges of the strand, as is shown in plate 30, figure 2. The xylem on the upper side of the trace thins to one or two tracheids in thickness, and the identity of the internal sclerenchyma is lost by reason of its similarity to that of the cortex, with which it is in direct connection.

Phyllopodium.-Very rarely are free leaf basesphyllopodia-observed in the sections of Tempskya knowltoni Seward. Where they are present they are usually in an advanced stage of decomposition and disintegration, as attested by the clogging of lumens with dark gumlike deposits, maceration of cells, and dislocation of tissues. As a result, though the series of stages leading up to the phyllopodium is complete, the sum total of knowledge of the mature organ is very small. It is certain, however, that the single vascular strand of the leaf trace persists and is modified into the highly convoluted meristele described for the genus as a whole.

Roots.-The mass of the specimen is, as in other species, a mat of branching roots, which differs little within the genus. The xylem is diarch, with two or 
three centrally located tracheids of unusually large diameter. The phloem and pericycle are well developed, and the stele is limited by an endodermal sheath. The cortex is similar to that of other species.

Comparison.-The only species of Tempskya previously described that is well enough preserved to permit accurate comparison is Tempskya rossica Kidston and Gwynne-Vaughan. ${ }^{19}$ It has been suggested that these species may be identical, the apparent differences being due to the derivation of the specimens from proximal and distal portions of the false trunk, respectively. ${ }^{20}$ In the writers' opinion these two species are distinct, although they admit that considerable variation may be expected in different parts of the same axis and between different individuals of the same species. The most obvious differences are as follows:

1. The size of the individual stems. According to the account given by Kidston and Gwynne-Vaughan, the stems of their species are much larger than those of Tempskya knowltoni.

2. The symmetry of the false stem. In Tempskya rossica the stems are arranged roughly according to a plan of radial symmetry. T. knowltoni shows a distinct dorsiventrality. This variation in the plan of symmetry is, in the writers' opinion, a character of some value.

3. The length of the internodes. In Tempskya knowltoni the internodes are of such length that only rarely does a trace remain in the cortex of the axis at the third node above the point where it originated. The figures of $T$. rossica indicate that the internodes were somewhat shorter in that species.

4. The nature of the xylem. The xylem of Tempskya knowltoni is homogeneous, but in T. rossica a considerable quantity of parenchyma is present.

Tempskya knowltoni Seward is quite distinct from the species described as new in this paper. Comparisons are presented elsewhere (pp. 116, 118).

Occurrence: Colorado shale (Upper Cretaceous), about 500 feet above base, about 10 miles southeast of Harlowton, Mont., in sec. 36, T. 7 N., R. 16 E. Collected in 1908 by A. C. Silberling.

Holotype: U. S. Nat. Mus. 39266.

Tempskya grandis Read and Brown, n. sp.

Plate 29, figure 2 ; plate 32 , figures $2-5$; plate 33 , figures $1-4$; plate 34 , figures $1-4$; plate 35 , figures $1-4$; plate 41 , figure 4 ; plate 42 , figures $1-3$; plate 43 , figures $1,4-7$

The collections of Tempskya made by W. W. Rubey and J. S. Williams in the Aspen shale of the Wyoming Range of western Wyoming include two very distinct species-one a small-stemmed form with long internodes and the other a large-stemmed form with crowded nodes. This large-stemmed form the writers propose to call Tempskya grandis.

\footnotetext{
${ }^{19}$ Kidston, Robert, and Gwynne-Vaughan, D. T., On a new species of Tempsky from Russia: Russ. k. min. Gesell. Verh., Band 48, pp. 1-20, pls. 1-3, 1911.

${ }^{20}$ Seward, A. C., Annals of Botany, vol. 38, no. 151, p. 498, 1924.
}

Gross aspect.-The type specimen of Tempskya grandis is a columnar fragment of a false stem about 8 centimeters in diameter and 20 centimeters long. The shape in cross section is oval, as is common in the false stems that have been examined. The weathered surface is quite like that of $T$. knowltoni Seward.

Plate 29, figure 2, illustrates the general aspect in cross section of Tempskya grandis at a low magnification. The stems are large as compared with $T$. knowltoni Seward and differ in several notable respects, as shown below. Text figure 3 (p. 108) is a carefully traced drawing of the false stem and the small stems included. The fact that these stems are dorsiventral shows clearly that there is a radial arrangement throughout so far as the orientation of these organs is concerned. Without exception the leaf traces that are sketched as $U$-shaped lines face toward the nearest point on the periphery of the mass. This arrangement of dorsiventral stems to simulate and probably to function in many respects as a single radially symmetrical axis is a very remarkable adaptation. The full significance of this feature is discussed on page 123 .

Anatomy of the stem.-Plate 32, figures 2-5, illustrates the general appearance of typical stems of Tempskya grandis when slightly enlarged. The vascular cylinder is, of course, a siphonostele. Numerous leaf traces at various stages of development are visible.

The epidermis of the stem is rarely well enough preserved to be studied. Ordinarily the outermost tissue is a thin layer of parenchyma, indicated in plate 34, figure 4. This tissue is what the writers have called' the outer cortex. Commonly it is deeply stained with some dark gummy substance. Immediately beneath the outer parenchymatous cortex is a region of sclerenchyma that constitutes the middle cortex. This feature is also indicated in plate 34 , figure 4 . This tissue is clearly very similar in histology to the comparable tissue in Tempskya knowltoni Seward but differs in its extent. A comparison of plate 31, figure 2 (T. knowltoni), with plate 34, figure 4 (T. grandis), immediately indicates that in $T$. grandis the amount of middle cortex is much less in proportion to the size of the stem than in T. knowltoni.

Beneath the tissue just described is a very well developed inner cortex, shown in plate 34 , figure 4 . In Tempskya knowltoni the parenchymatous inner cortex is a tissue of slight extent and presents no especially noteworthy features. In $T$. grandis, however, a somewhat different and significant condition is manifested. Plate 34, figures 2 and 4, shows that not only is this zone very well developed and fully as wide as that of the middle cortex but in addition there is an irregular band and commonly isolated nests of gummy sclerenchyma near the inner margin. Plate 34 , figures 1 and 4, illustrates a portion of the inner cortex at a medium magnification and gives a good 
idea of the histology. The writers are inclined to accept this differentiation of the inner cortex as a character of specific value.

The endodermis in Tempskya grandis is usually rather definite. Beneath it lies a thin layer of pericycle, then phloem, and finally the sheathing parenchyma of the xylem. (See pl. 34, fig. 3.)

The cylinder of xylem is well developed and prominent. In detail it differs somewhat from that of Tempskya knowltoni Seward. Plate 33, figure 3, shows that the zone of small-lumened elements, which is so prominent in $T$. knowltoni on the periphery of the ring, is not so conspicuous in $T$. grandis. The writers examined over 100 cross sections of steles and in none of them found this region so well developed. The position of the protoxylem is problematic. It appears, however, that this may be exarch or very slightly immersed (see pl. 34, fig. 3) and limited to a very small amount. Another point of difference between $T$. knowltoni and $T$. grandis is the abundance of xylem parenchyma in $T$. grandis. Plate 31 , figures 1 and 2 , and plate 34 , figures 3 and 4 , show that abundant thinwalled elements are interspersed with the tracheids. These cells have all the outward aspects of parenchyma, and the writers can only interpret them as such. Similar xylem parenchyma occurs in most of the families of the Filicales.

In Tempskya grandis, as in T. knowltoni Seward, an inner phloem, pericycle, and endodermis are present, although these tissues do not form so extensive a zone as those on the exterior of the xylem.

The outermost tissues of the pith are extremely interesting for several reasons. Plate 34, figure 2, indicates that there exists just within the endodermis a zone of large-celled parenchyma containing nests of sclerenchyma, and these are particularly abundant in the vicinity of a leaf gap. As a comparable zone exists in the cortex just outside of the outer endodermis the two may have a common origin. The writers do not propose to enter into the highly controversial discussion of the origin of the pith in the Filicales, because the several theories that have been advanced are subjects foreign to the purpose of this paper. Nevertheless, regardless of the origin of the tissues, they seem to furnish very reliable criteria for specific differentiation.

The central portion of the pith is an area of sclerenchymatous tissue similar to that found in Tempskya knowltoni Seward. Plate 34, figüre 2, illustrates the general aspect of this region.

Leaf trace.-The illustrations of Tempskya grandis show that every section contains several leaf traces at various stages of development. A comparison of plate 32 , figures $2-5$, with plate 29 , figure 3 , shows clearly that the traces in $T$. grandis are more numerous in any given portion of the stem than in T. knowltoni. Consequently it may be inferred that in the former the inter- node was much shorter than in the latter, as the writers believe, or else the traces passed outward at a more acute angle. This abundance of leaf traces has enabled the writers to make a very detailed study of the origin and development of the vascular strands that lead to the lateral organs.

A very early stage in the origin of a trace is shown in plate 35, figure 4 (on the left). At this point only a slight protrusion of the xylem strand and a narrowing in width are material evidence that the stele is about to be interrupted. A somewhat later stage is shown in plate 32 , figure 3 . The protrusion seen in plate 35 , figure 4, has become plainly marked, and the stele is about to part at the point of formation of the upper termination of the trace. In plate 35 , figures 3 and 4 , this gap has appeared, and a very decided xylem loop has formed. Also a constriction of the stele at the point destined to be the lower termination of the trace is evident. These illustrations clearly show that a portion of the parenchymatous and sclerotic pith fills the concavity of the trace.

Plate 35, figures 3 and 4, shows the leaf trace shortly after the formation of a complete foliar gap. The trace consists of a narrow inverted U-shaped xylem strand, which is slightly swollen at the terminations and invested by phloem, pericycle, and endodermis. The concavity facing toward the parent stele contains a tissue that is histologically identical with the pith. An interesting feature is the development of a large amount of parenchymatous tissue containing nests and irregular patches of sclerenchyma in the region of the foliar gap. As previously stated, this tissue is characteristic both of the inner cortex and of the outer pitb. There is a connection between these two usually separate units at the gap, and nests of sclerenchyma actually lie in the opening.

In plate 32 , figure 5 , the trace is shown in the sclerenchymatous cortex. Its general configuration is similar to that just described, but the terminations tend to curve inward. The investing tissues are very interesting. The characteristic parenchymatous and sclerotic tissue that sheathes the parent siphonostele both within and without occurs as a comparable sheath to the trace.

Plate 32, figure 3, illustrates a somewhat later stage in development of the trace. The ends are recurved, and it may be assumed that there is a progressive tendency toward this curvature, which has its extreme development at the base of the phyllopodium.

A very significant point, which the writers wish to emphasize, is the apparently short length of the internodes in Tempskya grandis as compared with $T$. knowltoni Seward. The numerous foliar traces that occur in every transverse section of a stem are bighly indicative of such a condition. Likewise it is worth noting that almost invariably the sections of the central steles show foliar gaps. In contrast, $T$. knowltoni Seward shows not uncommonly a completely closed 
stelar cylinder, and likewise the traces are never so numerous in any one section.

Phyllopodium.-In plate 42, figure 1, a phyllopodium of Tempskya grandis is shown in transverse section. The xylem strand is a modified; inverted $U$ with the terminations swollen and strongly incurved. The dorsal convexity is flattened and tends to flex downward medially. Except for the terminations the xylem is rarely over two tracheids in thickness and commonly only one. The protoxylem, as in the solenostele, is problematical, for no spiral or annular elements have been observed. From the size of the tracheids, however, it appears that there are three groups of endarch protoxylem, one occupying the ventral surface of each of the swollen terminations and the third at the point of flattening of the medial portion of the strand. An endodermis completely encases the stele, following the contour of the xylem. A considerable amount of phloem exists externally but is clearly reduced internally.

The extrastelar tissues are extremely interesting. The exterior of the phyllopodium consists of a poorly preserved epidermis beneath which is a small amount of parenchyma. In some specimens this tissue is clearly reduced to isolated areas that contain only a few cells. The bulk of the outer mass consists of a thick zone of sclerenchymatous tissue, apparently homologous with the middle cortex of the stem. Within this sheath lies a broad tract of large-celled parenchyma containing an irregular zone and isolated patches of sclerenchyma. This tissue is similar to and probably histologically identical with the inner cortex of the stem. As shown in the illustration, the area is continuous with the similar area on the inside of the bay of the meristele. The central portion of the bay is occupied by a mass of sclerenchyma.

Root.-The root varies so little in the several species of Tempskya examined that the generic description may be taken as a general account. The stele is diarch and is limited by a readily distinguishable endodermis, and the cortex is almost entirely sclerenchymatous.

The roots branch freely and occur in a variety of sizes. So far as the writers have been able to ascertain they are essentially parallel to the course of the stems, although they may locally deviate considerably from the course.

Comparison.-Tempskya grandis stands so distinctly apart from the several other species of the genus which have been described that there can be no question of its validity. Probably its nearest relative, if the details of vegetative anatomy may be taken as a guide, is T. rossica Kidston and Gwynne-Vaughan, ${ }^{21}$ from a Tertiary conglomerate in the Karaganda River Basin

\footnotetext{
${ }^{21}$ Kidston, Robert, and Gwynne-Vaughan, D. T., On a new species of Tempsky from Russia: Russ. k. min. Gesell. Verh., Band 48, pp. 1-20, pls. 1-3, 1911.
}

of Russia. However, the specimen appears to have been reworked from older, probably Cretaceous rocks. According to Kidston and Gwynne-Vaughan this species is characterized by

stems 6-7 millimeters in diameter. Leaves very closely inserted, indications of two leaf traces being present in each transverse section of the stem. Vascular system a solenostele. Xylem parenchymatous, tracheae scalariform, rarely multiseriate, without definite protoxylem groups. Petiole about 5 millimeters in greatest diameter. Leaf trace in petiole horseshoe-shaped with median abaxial depression and incurved, slightly enlarged extremities. ${ }^{22}$

According to this diagnosis Tempskya rossica approaches $T$. grandis in size of the stems and in the parenchymatous condition of the xylem. In fact, the writers were inclined during their preliminary studies to identify the species here described as new with the Russian specimen. A number of differences have manifested themselves, however, upon careful study. The internodes are much shorter in $T$. grandis, as is indicated both by the serial sections and by the numerous leaf traces (commonly five or six) found in every cross section of a stem. This, of course, cannot be taken as a criterion of high specific value but coupled with other evidence may be accepted with slight reservation. More significant is the matter of the inner cortex. Kidston and Gwynne-Vaughan found that in T. rossica

the cortex consists of two distinct zones; that next the stele is composed of fairly large cells with comparatively thin walls, probably parenchyma. Then comes a zone of thick-walled sclerenchyma about half as wide as the inner cortex, and outside this there may be a few layers of thin-walled cells. ${ }^{23}$

No mention is made of the occurrence of an irregular zone of sclerenchyma near the inner border of the inner. cortex, and their figures do not indicate such a tissue. Such a zone, however, is invariably present in $T$. grandis and may be taken as a character of considerable systematic value. The similar outer pith found in $T$. grandis is also different from that in $T$. rossica, where "there is a zone of thin-walled parenchyma next the endodermis, while the whole of the central region of the stem is occupied by a mass of sclerotic cells." ${ }_{24}$ The outer pith and inner cortex of the phyllopodium, which are histologically identical with comparable regions of the stem, differ in the same manner in $T$. grandis and T. rossica.

Numerous differences between Tempskya grandis and T. knowltoni Seward have already been pointed out. The longer internodes, the narrow zones of inner cortex and outer pith, which are entirely parenchymatous, the absence of any appreciable quantity of xylem parenchyma, and the flattened meristele of the phyllopodium in T. knowltoni Seward are characters that serve as accurate indices to its segregation.

$$
{ }^{22} \text { Idem, pp. 13-14. } \quad 28 \text { Idem, p. } 9 . \quad 24 \text { Idem, p. } 10 .
$$


Also, if the single specimen of Tempskya knowltoni can be accepted as typical and entire, the dorsiventral symmetry of the false stem as contrasted with the radial symmetry of the aggregation in $T$. grandis may likewise furnish grounds for distinction. The writers are inclined to place some emphasis on this character in systematic work.

Occurrence: Material collected by W. W. Rubey a1 d J. S. Williams in porcelainlike beds of Aspen shale (Upper Cretaceous) about 400 feet above the Bear River formation (Upper Cretaceous) at a locality in sec. 17, T. 35 N., R. 115 W., in the Afton quadrangle, Wyo. In addition one specimen was collected by S. H. Knight, of the University of Wyoming, from the Aspen shale in sec. 14, T. 31 N., R. 115 W., Lincoln County, Wyo., and transmitted to the writers by G. R. Wieland, of Yale University.

Cotypes: U. S. Nat. Mus. 39267, 39164.

Tempskya minor Read and Brown, n. sp.

Plate 29, figure 1; plate 36 , figures $1-4$; plate 37 , figures 1-4; plate 38 , figures $1-4$; plate 39 , figures $1-4$; plate 40 , figures $1-4$; plate 41 , figures $1-3$; plate 42 , figure 5 .

In addition to Tempskya grandis the collections made by Rubey and Williams in the Aspen shale (Upper Cretaceous) contain a small-stemmed species of the same genus. Similar specimens are included in the small lot obtained from the Wayan formation of southeastern Idaho by Mansfield in 1930 and by Mansfield, Rubey, and Williams in 1931 and S. H. Knight from the Aspen shale in sec. 14, T. 31 N., R. 115.W., Lincoln County, Wyo. This species is of the same general stock as Tempskya knowltoni Seward; in fact, the relationship seems to be very close. The writers believe, however, that Tempskya minor is distinct and can, with care, be separated from T. knowltoni. Certain minor morphologic differences exist, and these appear to be constant. This separation may seem to some students to be of doubtful validity, but a careful study of the numerous figures should convince the observer that specific differences exist.

Gross aspect.-A sketch of a large transverse section of an entire false stem is shown in text figure 4 (p. 108). Only the outlines of the stems, leaf bases, and the steles of these organs have been drawn. A comparison with the sketch of Tempskya grandis shown in text figure 3 (p. 108) immediately indicates significant differences. With very few exceptions the stems are so oriented that their leaf bases face in one direction. In other words, the symmetry tends to be dorsiventral. Whether this is apparent or real it is impossible to say. Most of the specimens of this species are large and do not suggest mere segments of a much larger false stem. At present the writers prefer to regard the symmetry as real, although they admit the possibility that the dorsiventrality is only apparent.

In this respect Tempskya minor is similar to $T$. knowltoni. If the symmetry of $T$. minor and $T$. knowltoni is actually dorsiventral then there is a strong suggestion of two groups of Tempskyas-one typified by $T$. minor and the other by the radially symmetrical $T$. grandis. These problematic subgeneric groups are discussed more fully on page 122 .

Anatomy of the stem.-The general appearance of the stem of Tempskya minor is shown in plate 29, figure 1, and in plate 36, figures 1-4. The species conforms very well to the generic characters. The vascular tissues are arranged in a dorsiventral siphonostele. The leaf gaps are short, and the traces are inverted U-shaped. The cortex and pith contain prominent areas of sclerenchyma. A thick mass of adventitious roots sheaths each stem and binds the whole system into a false stem.

Plate 38, figure 3, illustrates outer tissues of a stem. The exterior is rarely well preserved but appears to consist of a few layers of large, thin-walled elements beneath the epidermis.

The middle cortex is an extensive area of sclerotic elements. In general this tissue is similar to that described in the cortex of Tempskya knowltoni Seward and $T$. grandis. However, it is not so highly sclerotized as in the other two species and does not form so thick a ring as in T. knowltoni.

The inner cortex is well developed. In proportion to the size of the stem the area occupied by this tissue is fully as broad as in Tempskya grandis. The elements are large and thin walled. The occurrence of nests or even isolated cells of sclerenchyma was not noted, in contrast with their universal occurrence in $T$. grandis, which was collected in the same beds.

The cortical tissues are limited by a distinct endodermis, which, however, is well preserved in only a few specimens. An inner as well as an outer endodermis is present. As in the other species described these become continuous at each foliar gap, closing around the free ends of the interrupted vascular cylinder.

In plate 41, figure 3, the details of the morphology of the stele are shown. The amount of tissue that can be identified with certainty as pericyclic is slight, much less than in either Tempskya knowltoni or $T$. grandis. Likewise the phloem and the sheathing parenchyma are reduced in amount, on both the exterior and the interior of the xylem.

The xylem ring is similar to that described for Tempskya knowltoni. In plate 39, figures 2 and 3 , the details of structure of this tissue are shown at a rather high magnification. The nearly continuous peripheral zone of small elements that has been tentatively regarded as protoxylem in $T$. knowltoni is represented by a discontinuous zone in $T$. minor. Likewise the ring is somewhat narrower in T. minor. The xylem appears to be wholly without parenchyma, another point of difference from $T$. knowltoni, in which xylem parenchyma occurs in very small quantity, though it is present in most sections. 
Within the inner endodermis there is a narrow zone of large-celled parenchyma enclosing a mass of sclerenchyma that extends to the center.

Leaf trace.-The stems of Tempskya minor are characterized by long internodes in comparison with the other species of Tempskya that have been studied. In consequence it is by no means uncommon to find transverse sections that show a continuous vascular cylinder and no sign of foliar interruption. (See pl. 41 , fig. 3.)

The first indication of the emission of a trace is a thinning of the xylem in the portion of the cylinder that is destined to pass into the rachis. At the same time there is a protrusion of the entire stele, which continues until a gap is formed on the upper side of the trace. The shape of the foliar strand then is that of a narrow, inverted $U$. Immediately afterward the lower termination of the strand is detached. The phloem, pericycle, and endodermis are continuous around the ends of the xylem, both in the parent stele and in the leaf trace. The gap is rather short and closes very soon after the departure of the trace.

In plate 37 , figure 2 , the aspect of the trace is shown shortly after its departure from the cylinder. It is a broad, shallow arch, obliquely ascending, with the xylem only 1 to 3 tracheids in thickness except at the swollen ends. Completely surrounding it is a thin layer of phloem, pericycle, and endodermis. Within this horseshoe-shaped mass is a narrow zone of parenchyma that partly encloses the sclerotic tissue, which is in connection with the sclerenchyma of the pith and unquestionably falls in the same morphologic category.

As the trace passes out through the cortex it becomes sheathed on its abaxial surface first with parenchyma and then with sclerenchyma from the middle cortex. Plate 37, figures 1-4, shows a series of stages in the development of the trace within the cortex. The stele is at first a broad, shallow $U$ with slightly enlarged ends, which becomes progressively more and more recurved as the trace passes out. At the same time a slight depression develops on the abaxial surface.

The protoxylem groups are as problematical in the foliar trace as in the central cylinder. Groups of small tracheids that are tentatively regarded as protoxylem occur at the inner surface of the enlarged terminations and at the centrally located depression of the stele. Though no indication of spiral or annular thickenings has been observed, it seems safe to assume that the traces are triarch-endarch.

Phyllopodium.-In plate 36, figure 1, the appearance of the rachis in transverse section shortly before it becomes completely detached is shown. The stele is a broad, flat arch with recurved and enlarged terminations. Near the center there is the prominent abaxial depression that has already been mentioned. The protoxylem is apparently triarch and endarch. Completely enclosing the xylem strand is a zone of phloem, pericycle, and endodermis, which follows the configuration of the xylem very exactly. Within the arch there is a thin layer of parenchyma, which is continuous with a smaller tissue on the outer surface of the stele. The center is a mass of sclerotic tissue likewise in connection with the similar layer on the exterior, which makes up the bulk of the rachis, as is clearly shown in the figure.

Numerous remains of rachides are found in the groundmass of roots. These are scarcely well enough preserved to warrant description. Generally the stele is decayed or reduced to an unidentifiable mass and commonly displaced. Two of these masses are illustrated in plate 42 , figure 5 . This common occurrence of rachides in the root felt of Tempskya minor is in decided contrast with the condition in T. knowltoni, where such organs are very rare.

Root.-No essential difference in root structure between Tempskya minor and T. knowltoni and $T$. grandis was observed. Therefore the details of structure of these organs need not be considered. In fact, the generic description suffices for all the species that are considered in this report.

Comparison.-The foregoing description clearly indicates that Tempskya minor is very distinct from its associate in the Aspen shale, T. grandis. To recapitulate: T. grandis is a large-stemmed species with very short internodes. The axis is characterized by a xylem containing abundant parenchyma and by an inner parenchymatous cortex of considerable extent containing an irregular zone of sclerotic cells. A similar tissue exists in the outer pith. The rachis contains a deep, highly recurved stelar arch surrounded by tissues similar to those in the stem. On the other hand, T. minor is a small-stemmed form with a homogeneous xylem and without fibrous masses in the inner cortex. The foliar meristele is a flat arch, not nearly so recurved at the ends. The internodes are very long. The false stem of $T$. grandis is radially symmetrical; that of T.minor is approximately dorsiventral. The differences are so numerous and so constant that there is little danger of confusing the two.

The distinction of Tempskya minor from T. knowltoni is much more finely drawn, yet the writers believe that the two species can be accurately separated if sufficient care is taken. The more noteworthy differences are the larger size of T. minor, the more compact xylem with groups of problematic protoxylem instead of a nearly continuous layer, the broader zone of inner cortex, the less sclerotic outer cortex, and the broader, flatter arch of the meristele in the base of the rachis. In $T$. knowltoni the xylem contains some parenchyma; in $T$. minor such cells have not been observed. Likewise it appears that in T. minor the leaves, as indicated by the common occurrence of rachides, were more persistent than in T. knowltoni, where such organs are very rare.

Of the European species Tempskya rossica is the only one well enough known to justify comparison. 
This species, however, is closely related to $T$. grandis and in consequence should not be confused with the plant here described. According to the original report, ${ }^{25} T$. rossica is characterized by short internodes and in consequence numerous foliar traces in cross section and by xylem parenchyma. The stems are very nearly the size of the larger ones in $T$. minor. However, microscopic examination should make the separation rather simple, for $T$. minor contains no xylem parenchyma.

Occurrence: 1. Porcelainlike beds of Aspen shale about 400 feet above the Bear River formation in sec. 17, T. 35 N., R. 115 W., Wyo. Collected in 1931 by W. W. Rubey and J. S. Williams. 2. Aspen shale in sec. 14, T. 31 N., R. 115 W., Lincoln County, Wyo. Collected by S. H. Knight and transmitted by G. R. Wieland.

3. Aspen shale on divide between middle and east forks of Hoback Creek near head, in sec. 18, T. 35 N., R. 115 W., Wyo, Collected in 1931 by W. W. Rubey and J. S. Williams. Another collection from this same locality was made by W. W. Rubey in 1933.

4. Terrace gravel in valley of Twin Creek near Fossil, Wyo. Collected by R. W. Brown in 1930.

5. Upper part of Wayan formation in secs. 17 and 19, T. $5 \mathrm{~S}$., R. 44 E., Idaho. Collected by G. R. Mansfield.

Cotypes: U. S. Nat. Mus. 39253, 39259, 39260; paratypes: U. S. Nat. Mus. 39163, 39254, 39255, 39256, 39257, 39258, 39261, 39262.

\section{Tempskya whitei Berry}

1911. Berry, E. W., Maryland Geol. Survey, Lower Cretaceous, pp. 295-299, pls. 37, 38.

The specimens designated Tempskya whitei by Berry in his report on the Lower Cretaceous floras of Maryland have considerable historic interest. They represent the first record of the genus in America and also the only one from the Atlantic Coastal Plain. In consequence the writers have devoted much more time to the study of the prepared sections than the very poor preservation would really warrant. The results have been rather unsatisfactory, as will be seen below.

Tempskya whitei Berry is a large-stemmed form with relatively short internodes, as is indicated by the numerous leaf bases. In most specimens it has been impossible to observe the details of the xylem ring, but in a few of the best-preserved stems it appears to be from 7 to 12 tracheids in thickness and very sparingly parenchymatous. The protoxylem is in its usual position on the exterior of the cylinder. The cortex and "pith" are so poorly preserved in all the sections that their detailed structure cannot be determined. The leaf traces are apparently similar in form to those of the other species described in this paper.

The above remarks are intended to justify the writers' opinion as to the validity of the generic determination of this material. The very poor state of preservation makes it impossible to formulate a specific diagnosis at this time.

\footnotetext{
${ }^{25}$ Kidston, Robert, and Gwynne-Vaughan, D. T., op. cit., 1911 $75417-37-2$
}

Occurrence: Patapsco formation (Lower Cretaceous). The specimens examined by the writers came from Stony Run and Deep Run near Severn, Anne Arundel County, Md.

Plesiotype: U. S. Nat. Mus. 39264.

\section{Tempskya sp.}

A small fragment of a large false trunk of Tempskya from the La Sal Mountains of Utah has come to the writers through the kindness of Frank L. Hess, of the United States Bureau of Mines. This specimen is, unfortunately, a mass of diarch roots without any recognizable stems. In consequence it is impossible to assign the material to any species, as the roots do not afford any specific criteria. The record is of value only in that it further outlines the geographic and stratigraphic distribution of the genus.

Occurrence: Collected by F. L. Hess in the La Sal Mountains, Utah, on the divide southwest of Winburn's ranch, near the head and northwest of Pack Creek; probably from the Upper Cretaceous Dakota (?) sandstone.

Holotype: U. S. Nat. Mus. 39265.

\section{SYNOPSIS}

The writers have prepared a concise synopsis of the chief characters that serve to segregate the several better-known species of Tempskya. This synopsis may be of value not only for general reference but also for aid in identification.

1. Individual stems of false stem large, with very short internodes as indicated by the numerous leaf bases present in transverse sections. Xylem exarch or possibly slightly immersed in some specimens. False stem chiefly radially symmetrical. Xylem ring containing much parenchyma:26

A. Inner cortex a broad zone of parenchyma containing near its inner margin an irregular but continuous tract of sclerenchyma. Outer layer of "pith" a similar zone of parenchyma containing sclerenchyma, especially in the vicinity of the nodes.................. Tempskya grandis.

B. Inner cortex a narrow zone of large-celled parenchyma. Presence of an inner sclerotic layer not recorded ................... Tempskya rossica.

2. Individual stems of false stem small, internodes of such length as to permit only a little overlapping (2-3) of leaf bases. Xylem exarch. False stem dorsiventral. Xylem ring containing little if any parenchyma:27

A. Xylem very compact; protoxylem commonly segregated into definite groups. Inner cortex broad, parenchymatous. Petioles common in false stems, indicating persistence of leaves; xylem arch fairly flat. Stems averaging larger than those in the next group............ Tempskya minor.

B. Xylem compact but with parenchyma in places interspersed with the tracheids. Inner cortex usually narrow, parenchymatous. Petioles rare in false stem; xylem arch rounded.

Tempskya knowltoni.

${ }^{26}$ Under 1 may probably be included such indifferently preserved and poorly known species as Tempskya whitei, T. erosa (some forms), T. pulchra, T. macrocaula, $T$. microrrhiza, and T. schimperi.

${ }^{27}$ Some forms of Tempskya erosa belong in this group. 


\section{TAXONOMIC POSITION}

\section{AFFINITIES OF TEMPSKYA}

In their admirable discussion of Tempskya rossica Kidston and Gwynne-Vaughan stated that

The affinities of the Tempskyas appear to lie with the leptosporangiate ferns, but beyond this their systematic position must at present be left uncertain. $* * *$ For instance, stems with a solenostelic vascular system are known to occur in the Schizaeaceae, Gleicheniaceae, the Dipteris-Matonia series, in Loxsoma, the Cyatheae, the Dennstaedtineae, and in certain series of the Polypodiaceae. ${ }^{28}$

Even with the discovery of abundant new material these statements, though conservative, must still be accepted as expressive of the somewhat nebulous ideas concerning the affinities of Tempskya.

The writers have made a careful survey of the literature dealing with the vascular anatomy of the ferns in the hope that it would be possible to establish the systematic position of the genus. The results, though not so satisfactory as might be wished, narrow down the probable affinities somewhat and are therefore recorded.

The Eusporangiatae, as already stated, may at once be eliminated. The stems of the representatives of this group, both living and fossil so far as they are known, are quite distinct in their vascular make-up from those of Tempskya. Likewise there is the circumstantial evidence of the occurrence of sporangia of the leptosporangiate type entangled in the adventitious roots of Tempskya knowltoni..$^{29}$

Although within the Leptosporangiatae siphonostelic axes occur in groups that appear to be widely separated, yet there are certain characteristic features of Tempskya that immediately tend to eliminate several possibilities. The probable absence of spiral protoxylem, the exarch or very slightly immersed position of the protoxylem, the shape of the leaf trace and its mode of origin, and the outline of the vascular system of the petiole are criteria of great value in narrowing down the affinities. Without going into detail regarding the morphologic discrepancies that have permitted this elimination, it may be stated that certain members of the Schizaeaceae, Loxsomaceae, and Gleicheniaceae are anatomically more harmonious with Tempskya than any other ferns of which the writers have seen accounts. These families present features, however, that apparently do not conform with those observed in Tempskya.

The Schizaeaceae are a family that includes four living genera-Schizaea, Lygodium, Aneimia, and Mohria. Except for the last-named, all the genera include numerous species. The distribution is widespread but chiefly tropical. In habit there is a pronounced tendency toward dorsiventrality, although the radial con-

\footnotetext{
${ }^{28}$ Kidston, Robert, and Gwynr e-Vaughan, D. T., On a new speciês of Tempskya from Russia: Russ. k. min. Gesell. Verh., Band 48, pp. 16-17, 1911.

2y Seward, A. C. Annals of Botany, vol. 38, no. 151, p. 466, pl. 16, figs. 5, 8, 1924
}

dition persists in some species of Schizaea and Mohria and in most species of Aneimia. Repeated dichotomy of the stem characterizes all the dorsiventral representatives.

In the internal structure of the axis there is considerable diversity in the family, ranging from protostely to siphonostely and dictyostely. Among the siphonostelic members are encountered features that indicate an affinity with Tempskya.

The section Aneimiorrhiza of Aneimia forms a natural group of at least seven species, all having siphonostelic stems. Boodle ${ }^{30}$ has published an authoritative treatise on the anatomical features of these species and of Aneimia mexicana in particular. The stems are highly sclerotic and show a thin ring of xylem bounded without and within by phloem, pericycle, and endodermis. The protoxylem is usually scalariform and appears diffuse exarch, although this point is not made clear. In some species, however, the spiral elements of the protoxylem in the leaf trace may continue downward into the central axis for a short distance. The petiole of this species has not been studied in detail, but in the related Aneimia aurita an inverted narrowly Ushaped leaf trace passes out in a manner similar to that in Tempskya. A median and two lateral areas of protoxylems are present. The phloem and endodermis conform to the outline of the xylem but are absent in the deeper portions of the concavity. The protoxylem is confined to the inner surface. A hypodermal layer of sclerenchyma is present, but the petiole is not prevailingly sclerotic.

The xylem presents certain features that militate somewhat against a very close comparison with Tempskya. According to Boodle, parenchyma intermingled with the tracheids is rare. If comparisons were being drawn only between this family and species of the type of Tempskya knowltoni Seward the point might be made that the occurrence of parenchyma is too sporadic to be worthy of serious consideration. However, its abundance in Tempskya rossica Kidston and Gwynne-Vaughan and in Tempskya grandis makes the difference worthy of note. Another feature upon which Boodle lays particular stress is the occurrence of sclerosed sieve tubes in the phloem of representatives of all the genera except Mohria. Such fibers have not been observed by the writers in Tempskya, nor has any record of such an occurrence been brought to their attention.

Another character that may be of some value in discussing the affinities of Tempskya is the prevalence of diarch roots in the Schizaeaceae similar to those characteristic of the fossil.

The Gleicheniaceae include two genera-the monotypic Stromatopteris and Gleichenia-with about 80

${ }^{30}$ Boodle, L. A., Comparative anatomy of the Hymenophyllaceae, Schizaeaceae and Gleicheniaceae; II, On the anatomy of the Schizaeaceae: Annals of Botany, vol. 15, pp. 359-421, pls. 19-21, 1901. 
species. Their distribution is chiefly tropical and south temperate. Gleichenia has been divided into three subgenera-Mertensia, Eu-Gleichenia, and Platysoma. In species of Mertensia characters are seen that suggest a comparison with Tempskya. In most species of the genus a protostele characterizes the vascular axis, but in Gleichenia pectinata of the subgenus Mertensia there is a very interesting solenostele of a type highly suggestive of that in Tempskya.

In Gleichenia pectinata the stem is sclerotic. The solenostele carries numerous groups of slightly immersed protoxylem. Outer and inner phloem, pericycle, and endodermis are present. The central area is occupied by sclerenchyma. The stem is markedly dorsiventral, giving.off leaves above and roots below. At the node a band of tissue destined to pass into the leaf begins to separate from the xylem ring, the outer portion contributing more than the inner, in such a manner that the central sclerotic mass has a two-armed upward and lateral extension filling the concavity of the trace. The strand then splits off and gradually assumes an inverted U-shape with strongly recurved and somewhat swollen ends. The stele is left open for a time after the departure of the trace, so that there is free communication between central and cortical tissues.

In the petiole there is a prominent protoxylem group at each of the terminal hooks, and between lie an indeterminate number of groups derived from a centrally located protoxylem in the early stages of the leaf trace. A considerable amount of sclerenchyma is included in the convexity of the petiole, and the pbloem and endodermis are continuous within as well as without the xylem.

In this plant there are several points of disagreement with the observed facts of structure in Tempskya, chief among which are the definite and slightly mesarch protoxylem, which is spiral, and the mode of origin of the leaf trace.

Evidence of spiral protoxylem has not been noted in Tempskya, and its presence in slightly mesarch groups in Gleichenia pectinata is a significant point of difference. However, such protoxylem may exist in Tempskya but may have been obliterated during the course of silicification. This feature is in the writers' opinion an indecisive one.

The origin of the leaf trace plainly presents considerable differences between Gleichenia pectinata and Tempskya species. However, some question may be raised as to the systematic value of this feature.

Certain characters of the xylem necessitate the careful consideration of the Gleicheniaceae in this discussion. In its parenchymatous nature the ring is strongly suggestive of the stele of Tempskyas of the group of Tempskya rossica. Likewise the outline of the petiolar bundle and the distribution of the tissues in general in Gleichenia pectinata as well as in other species of the genus is strongly suggestive of Tempskya.
The Loxsomaceae, a family of ferns of the Tropics and the Southern Hemisphere, include two generaLoxsoma and Loxsomopsis, the former being monotypic. The anatomy of Loxsoma cunninghami has been fully investigated by Gwynne-Vaughan, ${ }^{31}$ and it is therefore possible to draw a rather careful comparison with Tempskya. The stem is a typical solenostele, a complete ring of xylem being invested on both sides by phloem, pericycle, and indodermis. The groundmass of the stem is chiefly sclerenchyma, although a thin layer of parenchyma adjacent to the inner and outer endodermis is similar to the feature that the writers have called the inner cortex. Scattered "islets" of parenchyma occur in sclerotic tissue of the groundmass, being abundant in the vicinity of the stele and disappearing farther away. The xylem is only a few cells thick and may be parenchymatous. "The protoxylem * * * consists of narrow scalariform tracheids evenly distributed around the external periphery of the xylem ring." 32

The closed stele is interrupted periodically along the upper side by the departure of leaves. At each node a portion of the ring separates and passes slowly outward as an inverted U-shaped meristele. Through the gap thus formed in the central cylinder there is free communication of medullary and cortical tissues. This gap may continue for some distance but never overlaps the succeeding one.

The vascular strand in the petiole thus developed is horseshoe- or inverted U-shaped, with the extremities enlarged and incurved. The protoxylem lies in several groups on the adaxial surface of the thin strand, one group occupying the bay of each of the incurved hooks and an indeterminate number being situated along the dorsal curve. The phloem, pericycle, and endodermis follow closely the contour of the xylem, although they may thin along the convex surface. The groundmass of the petiole is sclerer.chymatous in the proximal portions but becomes more parenchymatous higher up. The roots are diarch and similar to those in Tempskya.

Loxsoma cunninghani presents a number of features that suggest comparison with Tempskya. The exarch siphonostele with scalariform protoxylem, the sclerotic cortex, the dorsiventrality of the stem, the modified triarch, endarch leaf traces, and the diarch roots are all characters that are shared with Tempskya. However, the leaves are very nearly one-ranked, instead of two-ranked as in Tempskya, and the leaf trace is broader and flatter in outline. In Loxsoma islets of parenchyma related to the inner cortex are scattered in the sclerotic tissue for some distance from the stele, whereas in Tempskya grandis there are numerous islets and in fact an irregular sheet of sclerenchyma near the inner margin of the inner cortex. This feature may

s1 Gwynne-Vaughan, D. T., Observations on the anatomy of solenostelic ferns; I. Loxsoma: Annals of Botany, vcl. 15, pp. 71-98, pl. 3, 1901.

${ }^{32}$ Idem, p. 79. 
be taken as evidence of a trend toward sclerification of the parenchymatous cortex, with the possibility not remote of isolation of the softer tissue as islands. It is, of course, impossible to say how far this sclerification proceeded.

The above discussion shows that the writers are at a loss regarding the exact affinities of Tempskya. Professor Seward has urged that the genus be referred to the Schizaeaceae and has drawn a close comparison with Aneimia. ${ }^{33}$ The writers admit that there is much to be said in favor of this reference, including the circumstantial occurrence of spores and sporangia in the root felt, but on the other hand there are several serious discrepancies. Therefore it is proposed to erect, temporarily at least, a group designation for Tempskya and related fossil forms. For this group the family name Tempskyaceae is suggested. The limits of this family must for the present remain in doubt, and it may be temporarily regarded as unigeneric.

To recapitulate, the Tempskyaceae are a family of Mesozoic ferns including one genus, Tempskya. Several species are known. The affinities of the group lie with the leptosporangiate ferns, and trends are seen that suggest relation with the Schizaeaceae and the Loxsomaceae on the one hand and the Gleicheniaceae on the other. The limits of the family cannot be determined at present.

\section{INTERRELATIONSHIPS OF THE SPECIES}

The problem of the relationships of the species of any genus is invariably difficult-in fact, several solutions can usually be found that will be in harmony with the apparent trends of phylesis. The writers' views presented here are merely suggestions and are by no means intended to be dogmatic.

In the more formal systematic portions of this paper evidence has been presented which clearly shows that the genus Tempskya can be divided into two natural groups. Tempskya knowltoni Seward may be taken as the type example of one group. It is a smallstemmed form with relatively long internodes, thick sclerotic cortex, and xylem that is homogeneous. $T$. grandis may be taken as the type of the other group. It is a large-stemmed type with very short internodes, parenchymatous xylem, and a cortex differentiated into several layers.

To the first group the writers assign Tempskya minor in addition to $T$. knowltoni. To the second are referred T. grandis, T. rossica Kidston and GwynneVaughan, T. whitei Berry, some specimens of T. erosa Mantell, and probably the several species described by Corda.

The relative primitiveness of the two groups is of great interest. Unfortunately, as at present known their stratigraphic ranges are approximately the same. It appears that the group of Tempskya knowltoni is

33 Seward, A. C., Annals of Botany, vol. 38, no. 151, p. 499, 1924. more primitive so far as the morphology of the axis is concerned, and at the same time $T$. grandis presents several features that point to high specialization. The facts concerning this alleged primitiveness of $T$. knowltoni Seward may be summarized as follows:

The small stems with fairly long internodes seem more nearly typical of the solenostelic condition than the large stems with very short internodes that are exhibited in Tempskya grandis. In T. grandis it is at once evident that there is an approach to polystely and ventilation brought about by shortening of the internodal length, and as polystely, or any approach to it from the typical solenostele, is a distinct anatomical advance in the ferns it must be assumed that $T$. grandis is a more specialized representative of the genus.

The homogeneity of the xylem in Tempskya knowltoni may be taken as primitive, whereas the presence of abundant xylem parenchyma intermingled with the tracheids in T. grandis is some proof of advancement.

The cortex of Tempskya knowltoni is nearly homogeneous, consisting below the thin subepidermal zone of a broad belt of sclerotic tissue with only a few cells of parenchyma lying next to the endodermis. On the other hand, $T$. grandis has a cortex clearly divisible, below the subepidermal layers, into two zones-an outer sclerotic and a broad inner layer of parenchyma containing an irregular belt of sclerenchyma near its inner margin. It may be that the condition in $T$. knowltoni is primitive, or possibly it is a derivative of the condition in T. grandis.

There is indication that Tempskya knoultoni and others of the group present a dorsiventral symmetry in the false stem. T. grandis shows a distinct radial arrangement. It is reasonable to suppose that this dorsiventral condition preceded the radial one. This point is discussed above.

\section{PROBABLE HABIT OF TEMPSKYA}

The false stem, which is so characteristic of Tempskya, has been a subject of some discussion among paleobotanists because it brings up the very interesting problem of habit. A number of opinions on this point have already been considered in this paper, but for the sake of clarity it is necessary to restate briefly the conclusions of Kidston and GwynneVaughan and of Seward.

The aggregate of axes with their root packing must have stood upright. If they bad grown horizontally the roots would not have run parallel with the stems, and again the leaf-bearing sides of all the stems would have pointed in the same directionthat is, away from the soil. The whole aggregate of axes and roots undoubtedly reached a very considerable height and size, for Fitton describes specimens of the fossil measuring as much as 9 feet long, 1 foot wide, and 4 inches thick. ${ }^{34}$

An examination of the American material leads me to express an opinion different from that of Kidston and Gwynne-Vaughan. * * * The general though not invariable tendency of the

${ }^{34}$ Kidston, Robert, and Gwynne-Vaughan, D. T., On a new species of Tempskya from Russia: Russ. k. min. Gesell. Verh., Band 48, p. 14, 1911. 
roots to follow a vertical course does not $* * *$ justify the assumption of an erect position. The mass of compact roots seen in the fossil was probably covered during life by a much looser felt of roots which grew into the soil ***. Moreover, hydroptropism as well as geotropism must be taken into account. $* * *$

I believe that the available evidence supports the conclusion that the false stem of Tempskya, or at least of $T$. knowltoni, may best be compared with the obliquely ascending and for the most part subterranean stem of such a fern as Dryopteris filix mas. ${ }^{35}$

The new material which the writers have examined introduces some evidence that may help in the solution of the point at issue. Text figure 3 (p. 108) is a carefully prepared sketch of a cross section of an entire false stem of Tempskya grandis.

An interesting feature is the orientation of the true stems. Almost without exception they face directly toward the nearest point on the periphery of the massthat is, there is a definitely organized radial arrangement in the false stem. The roots take a course parallel or very slightly divergent to that of the subparallel stems. Any deviations of great magnitude can be explained by the crowding and are purely local.

The most reasonable interpretation of this feature is, in the writers' opinion, that Tempskya grandis was an upright-growing plant, possibly with an axis of considerable length. It is difficult to harmonize any idea of a subterranean, oblique, or horizontal rootstock with the evidence. The height to which such a fascicle might rise with any degree of erectness is a matter for academic discussion. The mat of roots might prop the mass up to a considerable height, although such an arrangement is not so mechanically sound as a single stem of the same size. Probably the false stem tapered upward-that is, was conical-notwithstanding the evidence of Tempskya knowltoni Seward to the contrary. Though the base may have contained only a single stem it must be admitted that the mass of roots might be enlarged there and taper upward to the apex of the stems, where little other than the actual stems would be present. It is, of course, probable that most of the roots were produced only a short distance below the growing points. However, they probably elongated slowly, so that they could not attain such length as to increase noticeably the bulk of the false stem until they were some distance below the apex of the false stem. A significant feature pointing toward the formation of a swollen base and conical shape of the false stem is found in the fact that whereas roots are numerous root origins are relatively rare. This may be indicative of great length and profuse branching of the organs.

The condition in Tempskya knowltoni Seward is quite different. Text figure 2 (p. 108) illustrates the orientation of leaf bases in the false stem. Instead of a radial symmetry there is a very pronounced dorsi-

${ }^{35}$ Seward, A.C., On a new species of Tempskya from Montana, Tempskya knowltoni sp. nov.: Annals of Botany, vol. 38, pp. 498-499, 1924. ventral arrangement, which has led Seward ${ }^{36}$ to the guarded assumption that the plant was horizontal or obliquely ascending and probably subterranean. Much can be said in favor of this assumption. The occurrence of coniferous roots in the false stem is cited as proof of the subterranean position of the mass. The exact category in which these so-called roots are to be placed, however, is in the writers' opinion uncertain. Possibly they are crushed portions of small stems. If $T$. knowltoni was obliquely ascending it is strange that the roots should so nearly parallel the stems, and it is begging the question to call in the influence of hydrotropism.

Several possibilities have been overlooked in previous discussions of the habit of Tempskya knowltoni Seward and similar dorsiventral types. The writers suggest that such forms may have been inclined or oblique in accordance with Seward's views but aerial and clambering over very stee $\rho$ hillsides, or they may have been climbers, either on cliffs or steep rock surfaces, or else lianalike and climbing on arborescent plants. Although there is no evidence at present of nearby land with any considerable relief, it must be borne in mind that material of Tempskya is well adapted to transportation and might have been brought in by currents from more distant rugged areas. These ideas are no more than suggestions made reasonable by the following facts:

The dorsiventrality of the false stem is as satisfactorily explained by the assumption of a climbing or clambering habit as by a subterranean one.

The roots might be expected to serve efficiently as holdfasts.

The false stem, if it is regarded as a mechanical unit, should be quite efficient in a cliff climber or liana, inasmuch as the demands for the utmost strength and at the same time extreme flexibility are fulfilled. The very sclerotic nature of the stems and roots is ample evidence of strength, and the aggregation of roots and stems into a ropy mass without cohesion of the elements would seem to permit flexibility.

The decay of the older portions of the stems may be cited as a possible adaptation toward the perching of a plant in crevices or possibly on some other plant or else on its own dead false stem. The loss of the older portions of the false stem through disintegration would relieve the strain on the plant and would permit its more efficient function as a liana or clamberer.

The situation in Tempskya minor is exactly comparable to that in T. knowltoni. The false stem shows. a marked dorsiventrality, and in this species some of the masses are rather large, containing more than 50 stems. It is most probable, in some species at least, that dorsiventrality was the condition during the entire life of the plant and did not change to a radial symmetry as maturity was approached.

36 Seward, A. C., op. cit., p. 505. 
To summarize, there appears to have been considerable diversity of habit in the genus. Tempskya rossica Kidston and Gwynne-Vaughan and T. grandis certainly show a radial symmetry that may be linked with an upright habit. The exact height to which a false stem might rise is, of course, uncertain, but it could not have been very efficient. The basal portions were probably much enlarged by the concentration of roots, so that the mass tapered upward. Of course, there must have been a downward taper also in the extreme . basal region. In T. knowltoni Seward and T. minor dorsiventrality is very pronounced. The explanation may lie in the fact that the plant was subterranean and obliquely ascending. There is much evidence in favor of this assumption, but it is difficult to explain the course of the roots parallel to the stems if this is true. The writers offer as an alternative the suggestion that the plant was a liana but do not urge it, because it may present some fundamental difficulties.

The false-stemmed or "tempskyoid" condition is by no means peculiar to Tempskya. Several examples are known, both living and fossil, and Sahni, ${ }^{37}$ in a recent paper, has summarized the facts concerning them.

The best-known living ferns that possess false stems are Todea barbara Moore and Hemitelia crenulata Mettenius. In Todea barbara the trunk is rather massive but low. The individual stems are radially constructed and arise both through repeated bifurcation and by lateral branching. In $H$. crenulata the stems are entirely the result of lateral branching of a central axis. These branches grow horizontally at first but turn upward on reaching the surface. The size attained is considerable.

In Sahni's paper there is described a very interesting zygopterid fern, Clepsydropsis australis Sahni, of Westphalian age, from localities in New South Wales. Sahni has clearly shown that this plant produced a false stem

of numerous repeatedly forked leaf-forming axes and relatively stout, erect petioles, the slems and petioles being all bound together by and embedded in a packing of adventitious roots and aphlebeae. ${ }^{38}$

The false stem shows a distinct radial organization both in the individual stems and the composite mass. It is likewise suggested that Clepsydropsis antiqua and $C$. kingisica may have had false stems, although this has not yet been demonstrated.

These comparisons cannot be carried very far, for a number of reasons. In the first place, even though the systematic position of Tempskya is not definitely established, yet it is certainly quite distinct from any members of the Osmundaceae, Cyatheaceae, or Coenopteridaceae. The false stem of Tempskya is therefore the result of independent development and can be

\footnotetext{
37 Sahni, Berbal, On Clepsydropsis australis, a zygopterid tree fern with a Tempskyalike false stem, from the Carboniferous rocks of Australia: Royal Soc. London Philos. Trans., ser. B, vol. 217, pp. 1-37 (especially pp. 27-29), pls. 1-6, 1928.

3s Idem, p. 19
}

expected to differ in many significant respects from those developed in only distantly related families. Secondly, it is the only genus at present known to produce a false stem in which the individual axes are dorsiventral. Thirdly, it differs from other genera in that the aggregate is one of roots and stems with only a few petioles. In the other forms cited the petioles are notable constituents of the false stems.

\section{STRATIGRAPHIC SIGNIFICANCE OF THE TEMPSKY ACEAE}

The recognition of specific differences among the specimens of American Tempskyas reported in this paper raises the question whether the species so differentiated are of any value in stratigraphic segregation. To answer this question the writers have tabulated stratigraphic sections from the localities where the specimens were collected or nearby areas and have atteinpted thus to show the relation between these sections and also, in a general way, to show the age relation of the American to the European occurrences. (See pl. 27.) This tabulation gives some sections in rather complete detail; others are somewhat meager because fuller information was not available. The fossil fern flora associated with the Tempskya species is given in a column to the right of that giving the stratigraphic names of the beds. The floral lists are confined to the ferns because the Tempskyas were ferns and because a list of the total flora for each locality would make such a table unwieldy and would probably serve no useful purpose in this connection. The lists therefore invite comparison and supply material for conjecture as to the probable reference of foliage to Tempskya. The following comments apply to the localities and the sections in which Tempskyas occur. The distribution of the Tempskyas within the United States is shown in figure 6.

Maryland.-The first American Tempskya to be described was Tempskya whitei Berry. The type specimen and others were collected in the valleys of Stony Run and Deep Run, north of Severn, Anne Arundel County, Md. The specimens were exposed by erosion of the Patapsco formation, which, in the Maryland Geological Survey's volume on the Lower Cretaceous, ${ }^{39}$ is classed as the uppermost formation of the Potomac group (Lower Cretaceous). E. W. Berry, in discussing the age of the relatively large flora of the Patapsco formation, says: ${ }^{40}$

Moreover, the latter flora [Albian of Portugal] closely parallels the Patapsco, in that both mark the first abundant appearance of undoubted dicotyledons and a persistence of a considerable number of the earlier Cretaceous types, which survive in both the Patapsco flora and that of the Albian of Portugal.

On the basis of this close similarity between these two floras on opposite sides of the Atlantic, and the fact that both mark the first abundant appearance of Dicotyledonae, and the further

${ }^{39}$ Clark, W. B., Bibbins, A. B., and Berry, E. W., The Lower Cretaceous deposits of Maryland: Maryland Geol. Survey, Lower Cretaceous, 1911.

${ }^{40}$ Idem, p. 160. 
fact that the Patapsco formation is overlain unconformably by the Raritan formation, carrying an abundant and unmistakably Cenomanian flora, the Patapsco formation is considered of Albian age. The unconformity which separates the Patapsco formation from the underlying Potomac beds is believed to represent all or nearly all of the time interval represented by the A ptian stage of European geology.

Montana.-Tempskya knowltoni Seward was the next Tempskya to be described. This specimen, according to the locality labels and as reported by Seward, was collected in 1908 by A. C. Silberling in the Musselshell Valley at a point about 10 miles southeast of Harlowton, Mont. This information seemed rather indefinite to the writers, and accordingly after careful search they were fortunate in finding two letters by Silberling to F. H. Knowlton which gave the exact information required. The specimen was found in sec. $36, \mathrm{~T} .7 \mathrm{~N}$., R. 16 E., at a stratigraphic horizon "about 700 feet above the unconformity separating the Jurassic red

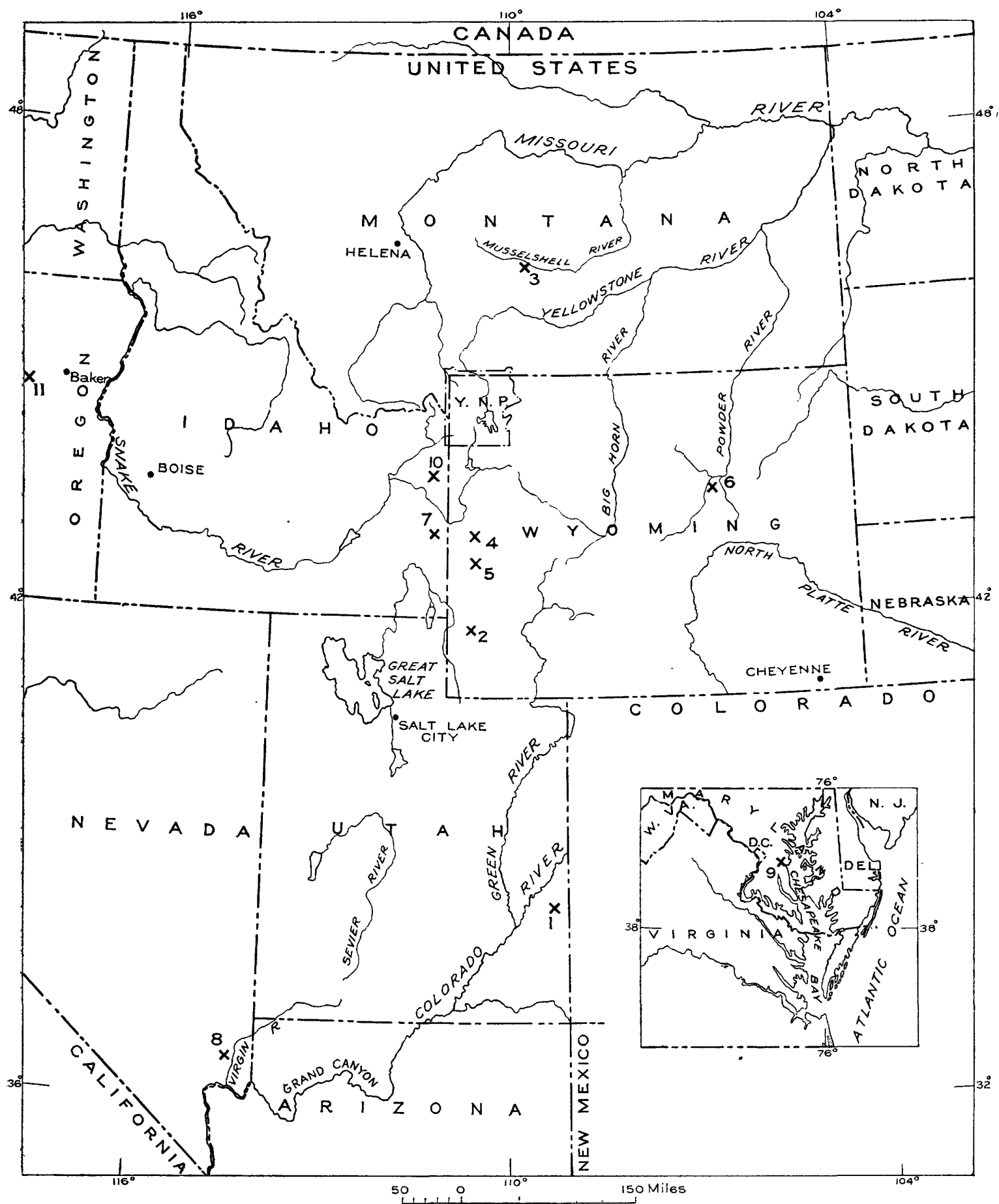

Figure 6.-Map showing Tempskya localities in the United States. 1, Head of Pack Creek, La Sal Mountains, Utah; 2, gravel terrace in T. 21 N., R. 117 W., Wyo.; 3, sec. 36, T. 7 N., R. 16 E., Mont.; 4, secs. 17 and 18, T. 35 N., R. 115 W., 7, secs. 17 and 19, T. 5 S., R. 44 E., Idaho; 8, halt a mile east of White Butte, 6 miles southwest of Kaolin, Clark County, Nev.; 9, mouth of Severn River, Anne Arundel County, Md.; 10, sec. 19, T. 5 N., R. 44 E., Idaho; 11, Lightning Creek, 1

Wyo.; 5, sec. 14, T. 31 N., R. 115 W., Wyo.; 6, sec. 28, T. 41 N., R. 81 W., Wyo.; mile north of Greenhorn, sec. 9, T. 10 S., R. 35 E., Oregon. 
beds from the Comanche and about 500 feet below the heavy Dakota sandstones." By superimposing this information on that acquired by later work the facts and terminology used by Silberling become clear. Plate 25 of Bowen's bulletin ${ }^{41}$ shows that the sec. 36 indicated by Silberling lies on the structural feature called East dome of the Shawmut anticline and that all the rocks that crop out within the section are of Upper Cretaceous Colorado age. The "Jurassic red beds" mentioned by Silberling are the maroon beds of the Kootenai formation (Lower Cretaceous). The Comanche of Silberling is the undifferentiated Colorado shale, and the "heavy Dakota sandstones" are the Big Elk sandstone member of the Colorado shale. The area in which the Kootenai crops out in the section next to the west, in Middle dome, is both topographically and stratigraphically lower, thereby making it improbable that the Tempskya specimen could reasonably have come from the Kootenai formation by the usual natural means of transportation of geologic materials. The writers are convinced that the specimen was derived from the lower sediments of Colorado age and very likely from the undifferentiated zone below the Big Elk sandstone member. This zone probably represents the stratigraphic equivalent of the Mowry shale or Aspen shale and the Frontier formation of adjacent areas.

Wyoming and Teton Basin, Idaho.-The new Tempskyas more particularly described in this paperTempskya grandis and Tempskya minor-were collected by W. W. Rubey and J. S. Williams in the folded Cretaceous area north of Kemmerer, in west-central Wyoming, and by Rubey in the Teton Basin, Idabo. The horizon is in the porcelainlike beds of the Aspen shale, about 400 feet above the Bear River formation; an excellent exposure is presented in the northeast corner of the Afton quadrangle, in sec. 17, T. 35 N., R. 115 W. The generalized section given below is supplied by Rubey, who writes:

The section is taken along part of the Green River-Snake River divide between Lookout Peak (southern end of the Hoback Range) and Deadman Mountain (northern end of the Wyoming Range). The beds that yield specimens of Tempskya are exposed at the head of Horse Creek.

\section{Section of Cretaceous beds in west-central Wyoming}

Lower part of Frontier formation: Alternating soft dark-gray sandy shale and brown thin-bedded calcareous medium- to coarse-grained sandstone, with conglomeratic lenses, some thick beds of unconsolidated sand, and poor coal near the base. Basal portion contains [coniferous] petrified wood and fragmentary [coniferous and dicotyledonous] leaves. Marine invertebrates at several localities in upper

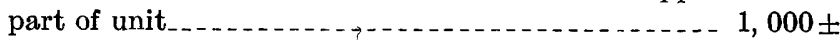

18 Bowen, C. F., Anticlines in a part of the Musselshell Valley, Musselshell, Meagher, and Sweetgrass Counties, Mont.: U. S. Geol. Survey Bull. 691-F, pp. 185-209, pl. 25, 1919.
Section of Cretaceous beds in west-central Wyoming-Continued

Aspen shale (harder and lighter gray than overlying and underlying units):

Gray shale, thin beds of sandstone, and tuffaceous

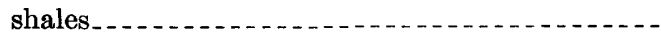

Gray shale, thin beds of light-gray tuffaceous sandstone, dark-green siliceous shale, and silverygray dense cherty argillite. Specimens of Tempskya locally abundant.................

Gray shale and thin beds of sandstone........ Bear River formation (shale unit): Black and dark greenish-gray shale and mudstone with thin ferruginous layers in some places; contains the typical Bear River fauna....................

Bear River formation (olive-brown quartzite unit, mapped as lower part of Bear River formation by A. R. Schultz): Very hard fine-grained olive-brown sandstone in 10 - to 50 -foot beds alternating with thicker beds of very dark gray shale................. Alternation of dense gray limestone, shale, and purplish, pink, and gray calcareous shale. Mapped as upper part of Beckwith formation by A. R. Schultz. Corresponds to Peterson limestone, Bechler conglomerate, and Draney limestone of southeastern Idaho...-.-

$200 \pm$

$600 \pm$

$400 \pm$

$250 \pm$

Westward these units thicken notably and undergo great lateral lithologic changes, making correlation difficult. The upper units are lost within a short distance, but the successively lower ones can be traced farther and farther westward. To judge merely by stratigraphic position and the general thickening, the Wayan formation of Idaho seems to occupy approximately the position of the upper part of the Bear River, the Aspen, and possibly the lower part of the Frontier of adjacent areas in Wyoming. This correlation is further suggested by the similar lithologic character of portions of the Aspen and Wayan units, and especially by the more coarsely granular tuffaceous beds in the middle member of the Aspen, which resemble strikingly in both their field and microscopic characteristics the tuffaceous beds in the upper part of the Wayan.

The Aspen deposits that yield Tempskya are regarded as near-shore marine with some lagoonal and coastal swamp facies. In the Wyoming Range and eastward and southeastward, particularly on the Meridian anticline southeast of Kemmerer, there are beds that carry marine fossils. ${ }^{42}$

One specimen of Tempskya grandis and one of Tempskya minor were collected by S. H. Knight, of the University of Wyoming, in sec. 14, T. $31 \mathrm{~N}$., R. $115 \mathrm{~W}$. As that section, according to A. R. Schultz's map, ${ }^{43}$ shows Bear River deposits in the eastern half and Aspen deposits in the western half, and as neither is well exposed, Knight is uncertain as to the exact horizon from which the specimens were

\footnotetext{
12 Reeside, J. B., Jr., and Weymouth, A. A., Mollusks from the Aspen shale (Cretaceous) of southwestern Wyoming: U. S. Nat. Mus. Proc., vol. 78, art. 17, pp. 1-24, pls. $1-4,1931$.

43 Schultz, A. R., Geology and geography of a portion of Lincoln County, Wyo.: U. S. Geol. Survey Bull. 543, pI. 1, 1914.
} 
collected but thinks that they probably came from beds near the top of the Bear River deposits. At any rate the material is not far from the lower limits of the Colorado group.

One small water-worn specimen of Tempskya minor was collected by R. W. Brown in June 1930 from a gravel terrace in the valley of the westward-flowing Twin Creek near the town of Fossil, in T. 21 N., R. $117 \mathrm{~W}$., Wyo., the regional geology of which is described by Veatch. ${ }^{44}$ The debris of this gravel terrace includes, besides other rocks, some pebbles of igneous rock, no outcrop of which occurs within the present drainage basin of Twin Creek. The gravel has therefore not been derived entirely from the Tertiary bedrock on which it lies, but a portion must have come from some exterior source. The specimen of Tempskya, if the diagnosis of the stratigraphic significance of the species is correct, came from Upper Cretaceous deposits of Colorado age. The nearest area of outcrop of such deposits to the point where the specimen was found is across the low divide and in the townships next to the east, where Bear River, Aspen, and Frontier beds occur just east of Kemmerer. The inference that the specimen came from this area seems reasonable, but it involves the necessity of explaining some changes in drainage which the writers believe have taken place but the elucidation of which they deem not within their present undertaking.

A small collection of fossil plants made in the Powder River oil field, Wyo., by C. H. Wegemann in 1910 has likewise yielded Tempskya minor. The specimen comes from a locality near the center of sec. 28 , T. 41 N., R. 81 W., at the horizon of a coal 25 feet below the base of the Mowry shale. Consequently it is from strata that are now called Thermopolis. Accordingly, the Thermopolis and the Mowry, which is conformable upon it, are considered to be correlated with the Aspen of western Wyoming - an idea that is well supported by other evidence.

Idaho, exclusive of the Teton Basin.--Several specimens of Tempskya minor were collected by G. R. Mansfield, W. W. Rubey, and J. S. Williams in the Lanes Creek quadrangle, southeast of Grays Lake and 40 miles west of the Horse Creek area, in Idaho. These specimens were found loose on the surface in secs. 17 and 19, T. 5 S., R. 44 E., in an extensive outcrop of the Wayan formation. Other specimens, according to Mansfield, were seen but not collected in the region northwest of Grays Lake. All these specimens were most probably derived from the uppermost beds of the Wayan formation, as these beds occupy the axial region of a broad syncline, and the course of the axis to the northwest in the region of Grays Lake Outlet marks the general line along which the specimens were found. The writers believe that

\footnotetext{
14 Veatch, A. C., Geography and geology of a portion of southwestern Wyoming, with special reference to coal and oil: U. S. Geol. Survey Prof. Paper 56, pl. 3, 1907.
}

the finding of Tempskya minor in the Wayan formation only 40 miles distant from the Aspen localities in Wyoming, in a region of relatively similar lithology, indicates a fairly close correlation in age, and that the Wayan formation, or a portion of it, may reasonably be regarded as of Colorado age and the time equivalent of the Aspen shale of Wyoming. This conclusion was also independently reached by $W$. W. Rubey in his field studies of the stratigraphy and lithology of these beds.

Utah.-Frank L. Hess, of the United States Bureau of Mines, during an investigation of the carnotite deposits in the region of the La Sal Mountains, Utah, found a specimen of Tempskya lying in the soil on deposits overlying the Upper Jurassic Morrison formation ( $\nmid$ McElmo ${ }^{45}$ of some reports). The locality is on the divide southwest of Winburn's ranch, near the head and on the northwest side of Pack Creek, just west of Mount Peale in the La Sal Mountains. As the specimen came from deposits above the Morrison, its source must lie between the Upper Cretaceous Dakota (?) sandstone and the Mancos shale. The Mancos shale is a dark marine shale deposit and is not likely to have contained the Tempskya. There remains the relatively thin deposit of light-colored Dakota (?) sandstone (about 40 feet), which, however, Hess did not distinguish as a separate unit in the section at the time of his visit. The outcrop of the Dakota (?) thickens and thins considerably in this area because its top was greatly eroded before the first deposits of the Mancos were laid down. It appears probable, therefore, that the Dakota (?) was the source of the Tempskya collected by Hess.

Nevada.-In 1934 fragments of Tempskya identified as $T$. minor were submitted to the writers by Eugene Callaghan and W. W. Rubey from the Overton fanglomerate, near Kaolin, Clark County, Nev. According to Rubey the fossils were obtained from the gray clays about 100 feet thick that constitute the basal member of the Overton. These beds have been reported as Tertiary. ${ }^{46}$ There is apparently no possibility that the material has been reworked from older deposits (Colorado Cretaceous). In consequence, at least the basal beds of the Overton, which are correlative with the Tempskya-bearing beds, must be regarded as Colorado in age. Additional evidence in support of this opinion is found in the occurrence of a specimen of Microtaenia paucifolia (Hall) Knowlton, which is a fern indigenous to the Frontier and Aspen formations of Wyoming.

Oregon.-Two well-preserved specimens of Tempskya having the appearance of jasper were collected in 1914 by J. T. Pardee from a placer pit on Lightning Creek

45 A dagger ( $\dagger$ ) preceding a geologic name indicates that the name has been abandoned or rejected for use in classification in publications of the U. S. Geological Survey. Quotation marks, formerly used to indicate abandoned or rejected names, are now used only in the ordinary sense.

${ }^{46}$ Longwell, C. R., Geology of the Muddy Mountains, Nev.: U. S. Geol. Survey Bull. 798, pp. 68-74, 1928. 
in the $\mathrm{NE}^{1 / 4} \mathrm{NE}^{1 / 4}$ sec. 9 , T. 10 S., R. $35 \mathrm{E}$., 1 mile north of Greenhorn, in the Sumpter quadrangle, Oregon. The age of the placer deposit has not been established but appears to be pre-Mascall. At any rate it is fairly certain that some of the material was derived from a Cretaceous source.

England.-Sussex, in southeast England, is crossed by a northwest-southeast anticlinal axis, which passes through Horsham and Tilgate Forest (St. Leonards) and emerges on the coast about 5 miles east of Hastings. This arch in the strata raises and exposes in the cliffs the Lower Cretaceous Wealden deposits known as the Hastings sands. This member of Wealden is commonly regarded as having three divisions, the lowest of which, the Ashdown sands, is, according to Evans, ${ }^{47}$ the source of specimens of Tempskya erosa. Dixon, ${ }^{48}$ however, gives a section in which he refers the $T$. erosa bands to either the upper part of the Ashdown sands or the lower part of the Wadhurst clays, but on page 144 he ascribes the T. erosa bands to the Wadhurst clays. The specimens weather out of the cliffs and accumulate on the beach near Ecclesbourne. Inland in Tilgate Forest presumably the same beds yielded the original specimens first reported by G. A. Mantell as "arborescent ferns" and later as Endogenites erosa. Tempskyas have also been collected from the Wealden of the Isle of Wight.

The occurrence of Tempskya erosa in the Lower Greensand (Aptian) at Potton, near Woburn, in Bedford, is discussed by Stopes ${ }^{49}$ as follows:

Regarding the distribution of Tempskya in the English Lower Greensand, so far as I can discover, the only specimens of the genus occur in the Potton sands. The beds at Potton are peculiar in containing a number of fossils which are certainly derived, it may be from the preceding Wealden deposits. These fossils generally show a richly colored, rolled, and often highly glazed surface, by which they can at once be distinguished by anyone well acquainted with the plants of the horizon. Of the specimens in the Museum, V. 13081 lacks the most noticeable characters of the derived fossils and might reasonably be regarded as a true Lower Greensand fossil. There is also one very fragmentary specimen from Ireland.

France.-Tempskya schimperi was collected by Carpentier ${ }^{50}$ from two localities in the Wealden of northern France-one near Glageon, the other near Fourmies, about 3 kilometers distant. The Wealden deposits in this area overlie unconformably the calcareous Givetian and Frasnian beds of the Devonian and the Bathonian beds of the Jurassic. Overlying the Wealden are sands and clays that resemble the Lower Greensand and Gault, and, in spots like the Bois de Montfaux, immediately west of Glageon, the Cretaceous elements are capped by Eocene sands and clays. The Wealden of this region is confidently correlated by Carpentier with that of England on the basis of no less

47 Evans, J. W., Geology of the British Isles, p. 248, 1918.

48 Dixon, Frederick, Geology of Sussex, pp. 142, 144, 1878.

1" Stopes, M. C., The Cretaceous flora, part 2, Lower Greensand (Aptian) plants of Britain; Catalogue of the Mesozoic plants in the British Museum (Natural History), p. 19, 1915.

so Carpentier, Alfred, La flore wealdienne de Féron-Glageon (Nord): Soc. géol Nord Mém., vol. 10, p. 48, pl. 11, figs. 3-10, 1927. than 22 species of fossil plants in common and with the Wealden of north Germany on the basis of 19 species of fossil plants in common.

Germany.-Tempskya schimperi (originally Endogenites erosa) was reported by Wilhelm Dunker from the Hils beds (Hastings sands) at Neundorf, near Hannover. T. cretacea, a species regarded by Hosius and Von der Marck as different from $T$. schimperi, was collected in the Senonian near Haltern, in Westphalia.

Bohemia (Czechoslovakia).-From the Peručer beds of the Cenomanian of Rynholec, near Lana, 35 kilometers west of Prague, Joseph Velenovsky described Tempskya varians. The section showing the horizon where this species was collected is pictured by Frič and Bayer. ${ }^{51}$ The Peručer beds of Bohemia have yielded 127 species of fossil plants.

The specimens of the four Tempskyas-Tempskya pulchra, T. macrocaula, T. microrrhiza, and T. schimperi-described by A. J. Corda in 1845 were sent to him by three different persons and were thought by him to have come from the gravel along the Elbe River east of Neupaka, in Bohemia. It is particularly unfortunate that the exact source of the nominal type species, T. pulchra, of the now well-characterized genus Tempskya should be unknown.

Russia.-The specimen described by Kidston and Gwynne-Vaughan as Tempskya rossica was collected (according to the locality citation given by them) in the basin of the Karaganda River, on the west flank of the Mugodjar Mountains. The locality is about 15 kilometers south-southeast of the Ber-Chogur station on the Tashkent Railway. That station is about 450 kilometers east of Orenburg and about 75 kilometers west of Chelkar. The specimen apparently came from a Tertiary conglomerate that includes pebbles of crystalline rock and Devonian and Carboniferous limestone and sandstone. According to the more recent work of Prigorovsky ${ }^{52}$ the Mugodjar Mountains, which are the southern extension of the Urals, heading toward the Ust-Urt Plateau between the Caspian and Aral Seas, are composed of igneous rocks-granite, diabase, gabbro, and porphyry - and of local disturbed or metamorphosed Devonian and Carboniferous sedimentary beds either covering the igneous rocks or being penetrated by them. On the west flank of the Mugodjars the upper drainage basin of the Emba River, of which the Karaganda is a tributary, is a region of Upper Cretaceous (Senonian) deposits that lie borizontally or almost horizontally but unconformably upon the older Paleozoic beds. Prigorovsky's map (his pl. 35a) shows Tertiary deposits bordering those of the Upper Cretaceous in the Emba Valley, but this map, doubtless on

51 Frič, Anton, and Bayer, Edvin, Studien im Gebiete der böhmischen Kreideformation; Palaeontologische Untersuchungen der einzelnen Schichten; Peručer Schichten: Archiv naturwiss. Landesd. Böhmen, p. 39, fig. 20, 1900.

52 Prigorovsky, M., Esquisse géologique des monts Mougodjars et des parties voisines des steppes de Tourgai et de l'Oural: Com. géol. [St.-Pétersbourg] Bull., vol. 33, pt. 2, pp. 889-928, pl. 35a, 1914 . 
account of its small scale and reconnaissance character, shows only Upper Cretaceous deposits at the locality where $T$. rossica is said to have been found. That unmapped Tertiary terrace materials exist there seems reasonable and that the $T$. rossica specimen was derived from the surrounding Upper Cretaceous sediments and was deposited in the Tertiary gravel is the conclusion which, in the opinion of the writers, seems to fit this situation most satisfactorily.

Conclusions concerning stratigraphic range.-The range of the genus Tempskya, as so far revealed, thus appears to have been from lowermost Lower Cretaceous time to Senonian time in the Upper Cretaceous. In America the record shows a range from the uppermost Lower Cretaceous to a point well up in the earlier portion of the Upper Cretaceous. The fact that the European specimens, with the exception of $T$. rossica, are so poorly preserved makes identification and correlation difficult or even impossible on the basis of similarity or dissimilarity of species.

The American Upper Cretaceous Tempskyas, as shown in the discussion of their anatomical structure, fall into two fairly well defined groups-the Tempskya grandis group and the Tempskya knowltoni and .T. minor group. The Lower Cretaceous T. whitei applears to belong to the latter group, but its preservation,' like that of the European specimens, is disappointing, and no definite statement can therefore be made in regard to its classification. The T. grandis group, to which also apparently belongs the Russian $T$. rossica, is regarded as anatomically more highly specialized than the $T$. knowltoni group. The $T$. knowltoni group would therefore indicate a somewhat earlier development, which is compatible with the geologic record if $T$. whitei and the European Lower Cretaceous species can ever be proved to belong to the T. knowltoni group.

\section{CONCLUSIONS}

As a result of the investigation of a considerable quantity of material of Tempskya from various sources in western America the writers reach the following conclusions:

1. The genus Tempskya is characterized by a freely dichotomizing, dorsiventral, siphonostelic stem system sheathed in a thick and dense felt of diarch adventitious roots in such a manner that a false trunk is developed. The leaves are two-ranked on the upper surface of the stems and are marked by the emission of simple inverted U-shaped triarch traces, which continue into the base of the phyllopodium with but slight modification. The characters of the species are not summarized here but are given in connection with the taxonomic details on pages $108-119$.

2. The symmetry of the false trunk is either dorsiventral, as in Tempskya knowltoni, or radial, as in T. grandis. This feature of false-trunk symmetry is suspected to be constant within the species.
3. The affinities of Tempskya are with the leptosporangiate ferns. There is evidence to indicate close proximity to the Schizaeaceae, but this is not conclusive. Certain features likewise indicate connections with the Loxsomaceae and the Gleicheniaceae. In view of this obscure relationship, a provisional family, the Tempskyaceae, is erected for the temporary inclusion of the genus.

4. The species that have been reported appear to fall into two natural subgeneric groups. The first is typified by Tempskya grandis and is characterized by large stems with short internodes, abundantly parenchymatous xylem, and a radial arrangement of the stems in the false trunk. The second group, the type example of which is $T$. knowltoni, is characterized by small stems with long internodes, a more homogeneous xylem, and a marked dorsiventrality of the false stem.

5. Of these two groups the one typified by Tempskya knowltoni is regarded as more primitive. The small stems with comparatively long internodes exhibit a more primitive solenostelic condition than those in the group of $T$. grandis, where, through a shortening of the internodal length, there is an approach toward polystely. The homogeneous xylem of $T$. knowltoni is taken to be less specialized than the parenchymatous xylem of $T$. grandis. The complex cortex of $T$. grandis is obviously an advanced character, although this is perhaps not a character of the whole subgeneric group. The radial symmetry of the false stem in $T$. grandis is regarded as probably derived from the dorsiventral stage represented by $T$. knowltoni.

6. As regards the habit, the stems of Tempskya grandis must have been upright. The radial symmetry of the false stem and the parallelism of the roots and stems is considered weighty evidence pointing in that direction. In the T. knowltoni group several possibilities are suggested. The symmetry of the false stem is dorsiventral, which may indicate a prone or obliquely ascending habit. The roots, however, run parallel to the stems, and this fact argues against such an explanation. As an alternative the suggestion is made that the plants may have been lianalike in habit or even epiphytic.

7. The few examples of false stems known in modern ferns are not comparable to the situation exhibited in Tempskya. Likewise the false-stemmed condition in other fossil ferns is somewhat different.

8. The occurrences of Tempskya, which have been reviewed, indicate that the stratigraphic range of the genus is from lowermost Lower Cretaceous to Senonian (late Upper Cretaceous). In western North America the genus is at present known definitely only from the lower part of the Colorado group, from the lower part of the Wayan formation, from the basal part of the Overton fanglomerate, and from beds that belong to either the top of the Bear River formation or the base of the overlying Colorado group. 



\section{PLATES 28-43}




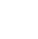

. 

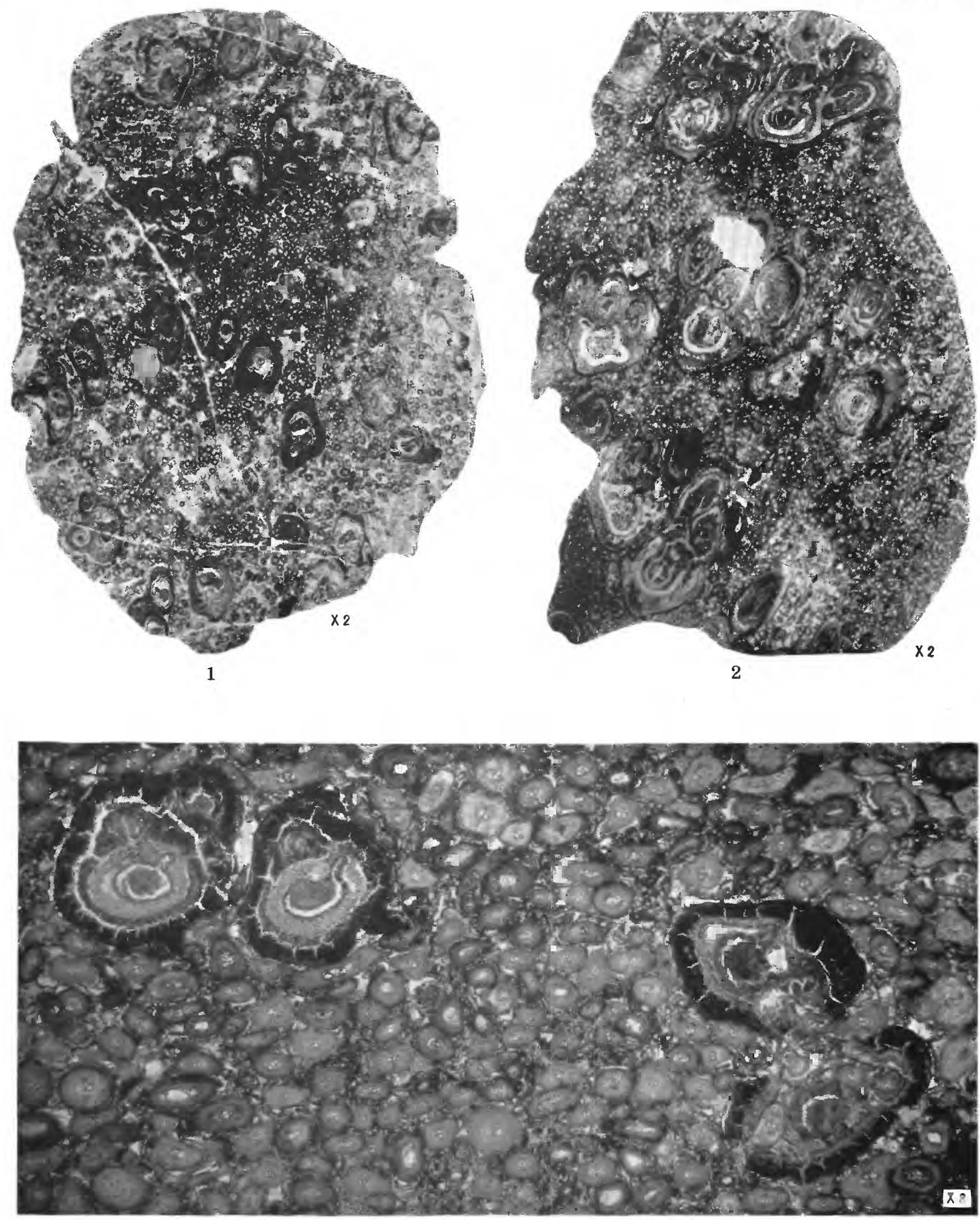

3

AMERICAN CRETACEOUS FERNS OF THE GENUS TEMPSKYA.

1, 2. Transverse sections of Tempskya knowltoni showing general aspect of false stem.

3. Portion of slide shown in figure 2 enlarged to show relations of roots and stems in more detail. 


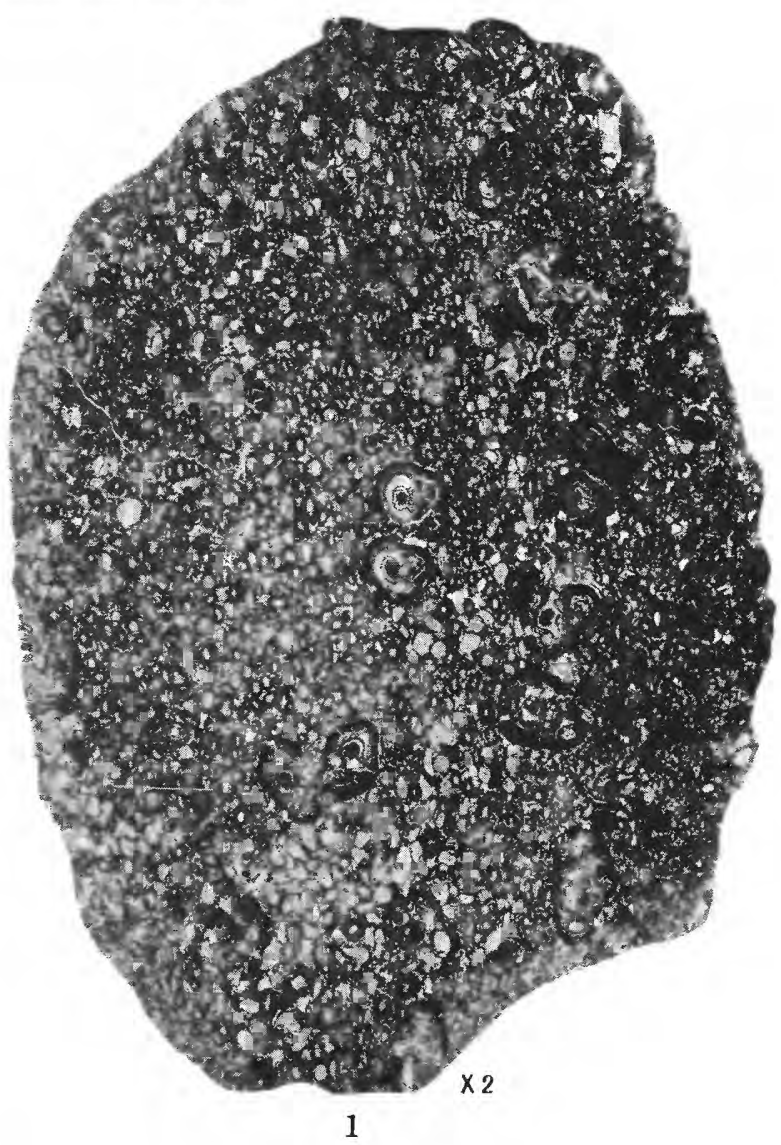

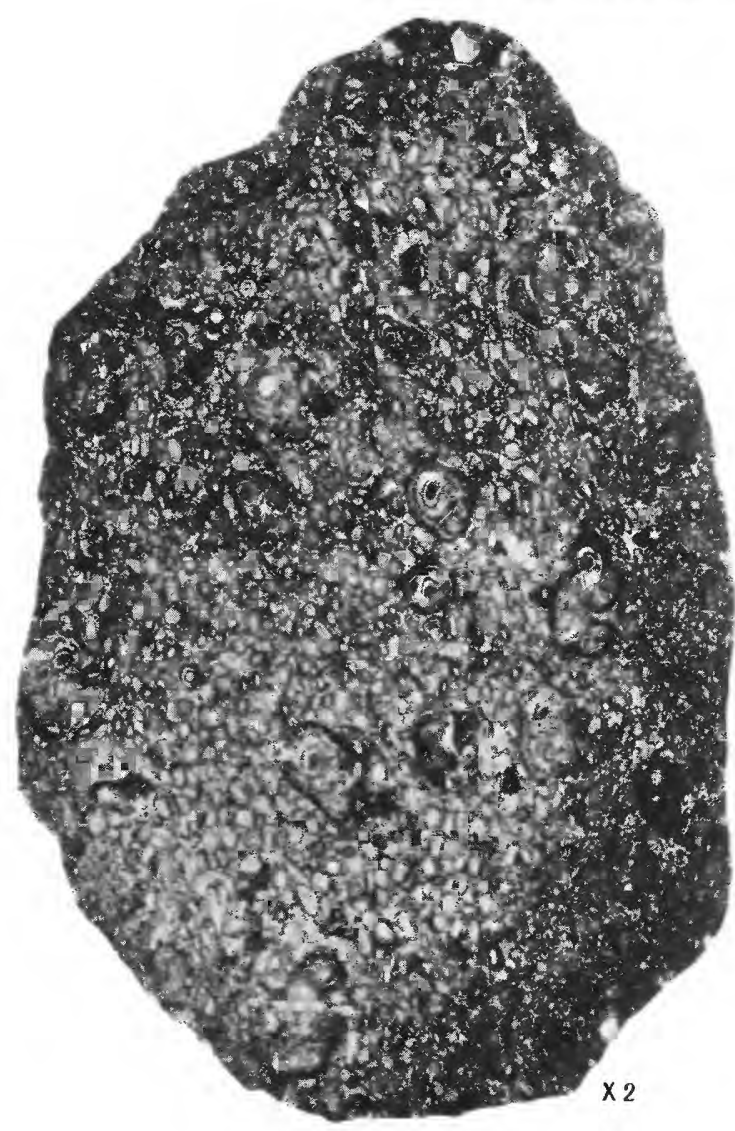

2

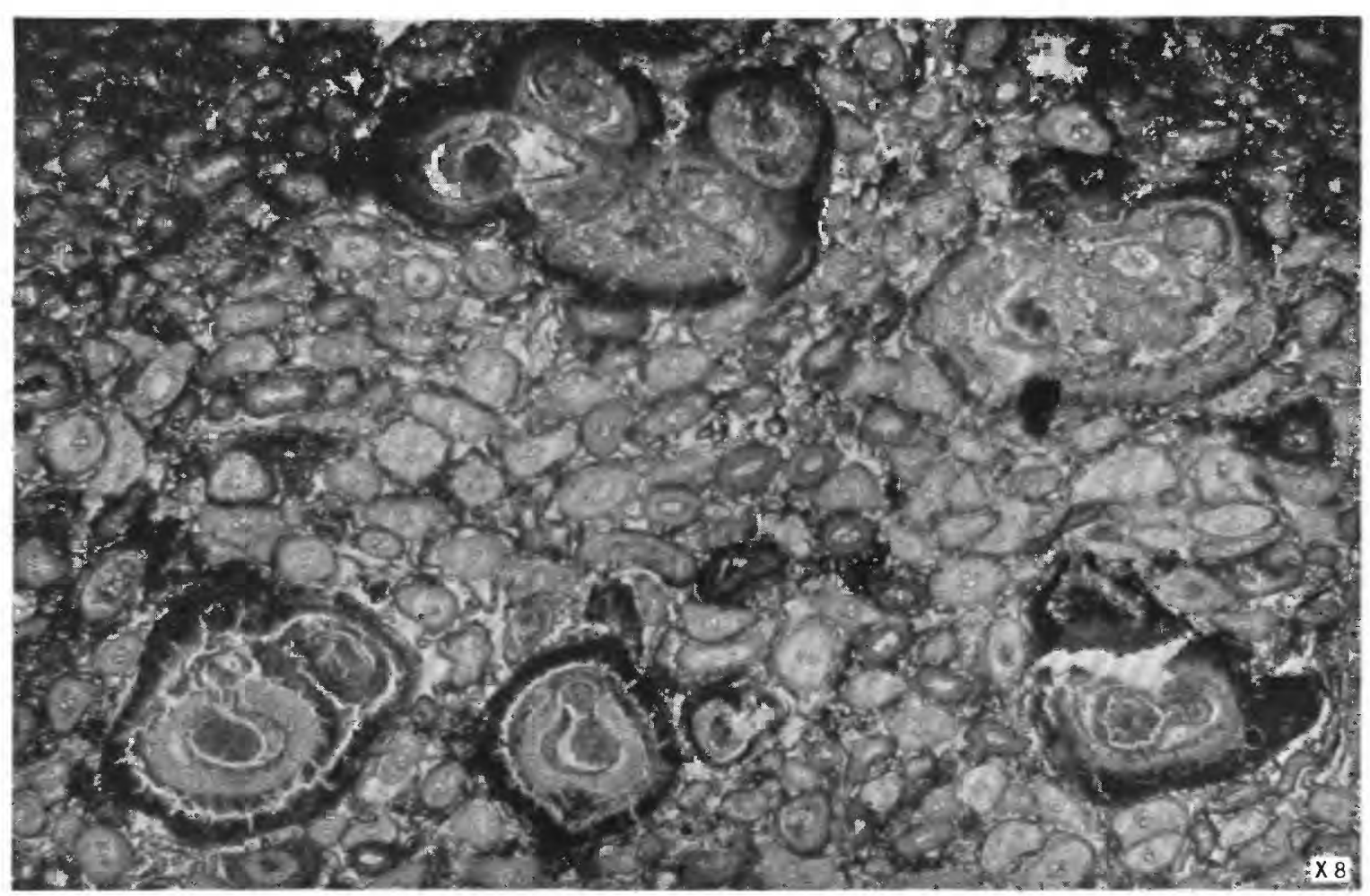

3

AMERICAN CRETACEOUS FERNS OF THE GENUS TEMPSKYA.

1. Transverse section of Tempskya minor.
2. Transverse section of Tempskya grandis.

3. Portion of section of Tempskya knowltoni shown in plate 28, figure 1, enlarged to show more detall. 


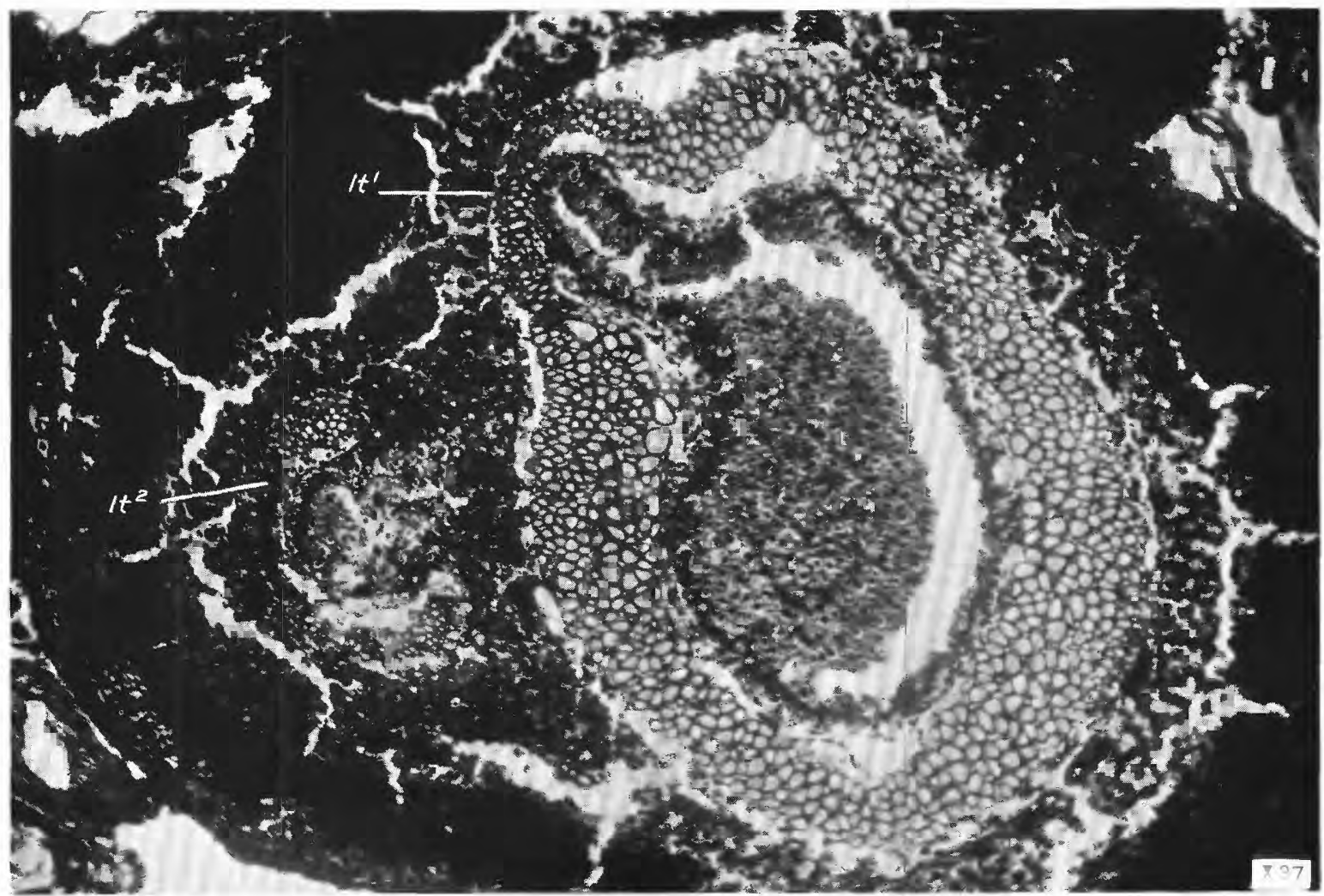

1

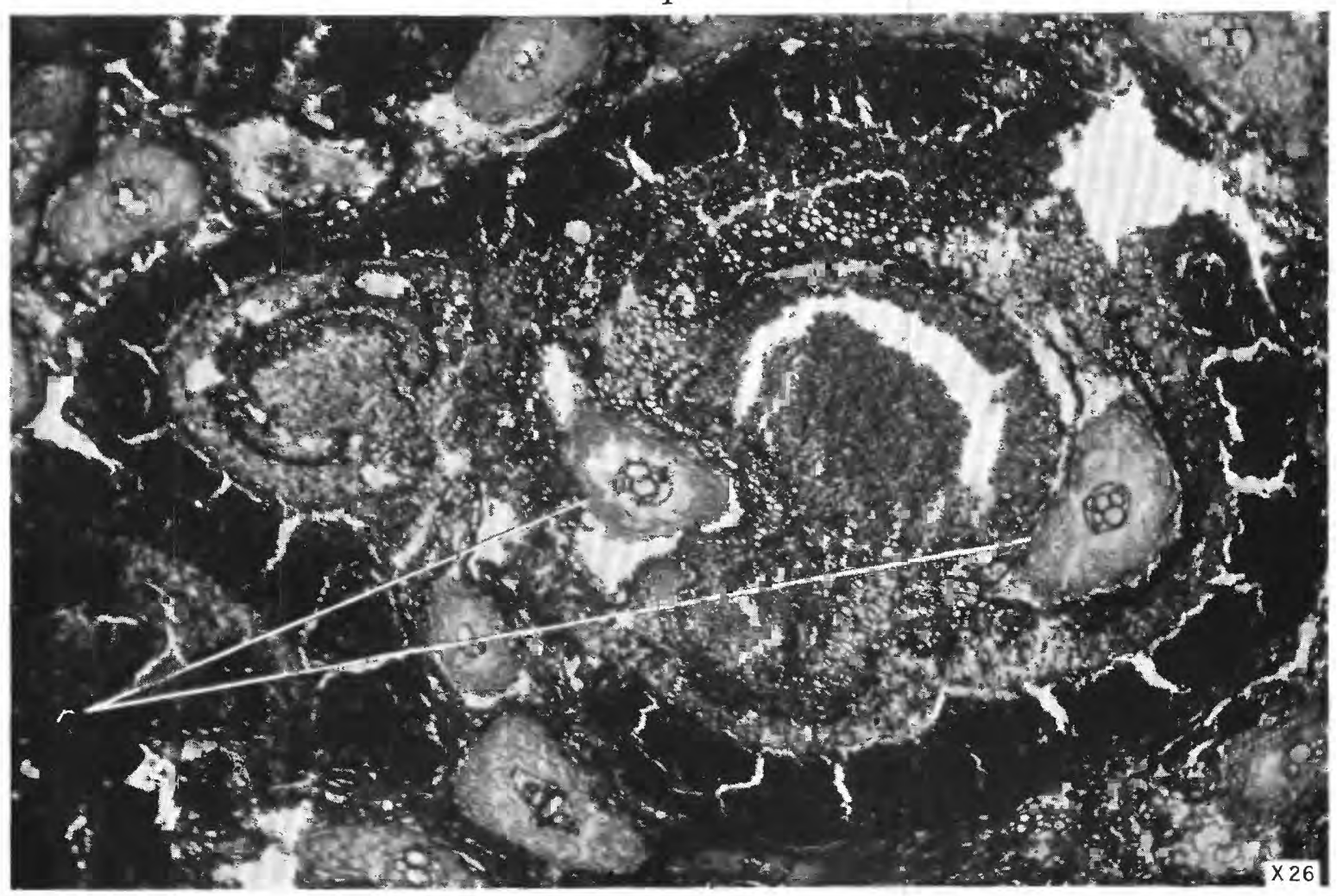

AMERICAN CRETACEOUS FERNS OF THE GENUS TEMPSKYA.

1. Transverse section of a stem of Tempskya knowltoni showing the characteristic solenostele. Note the leaf traces, $t^{t}$ and $t^{*}$.

2. Transverse section of a decayed stem of Tempskya knowltoni. Note the penetrating roots, $r$. 


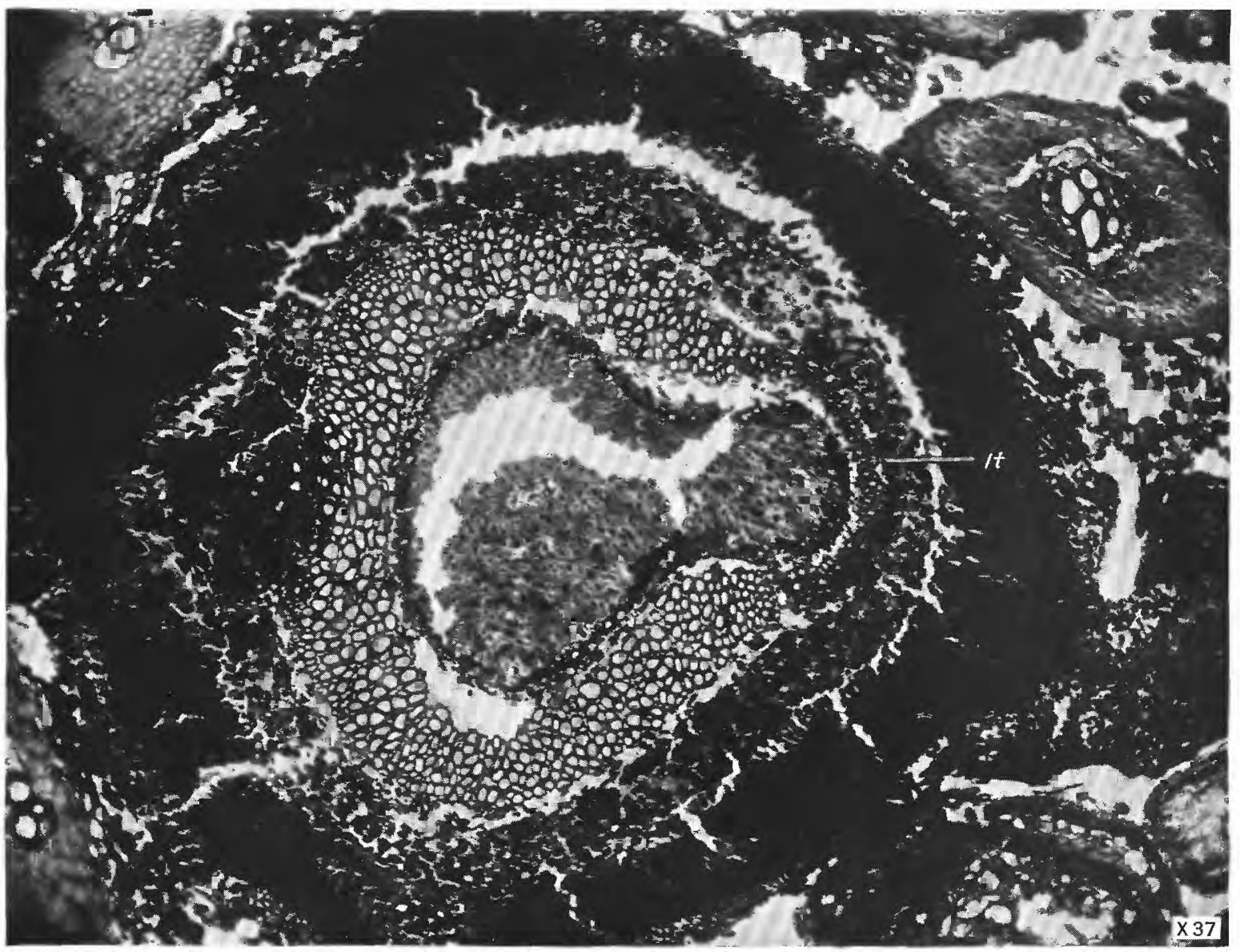

1

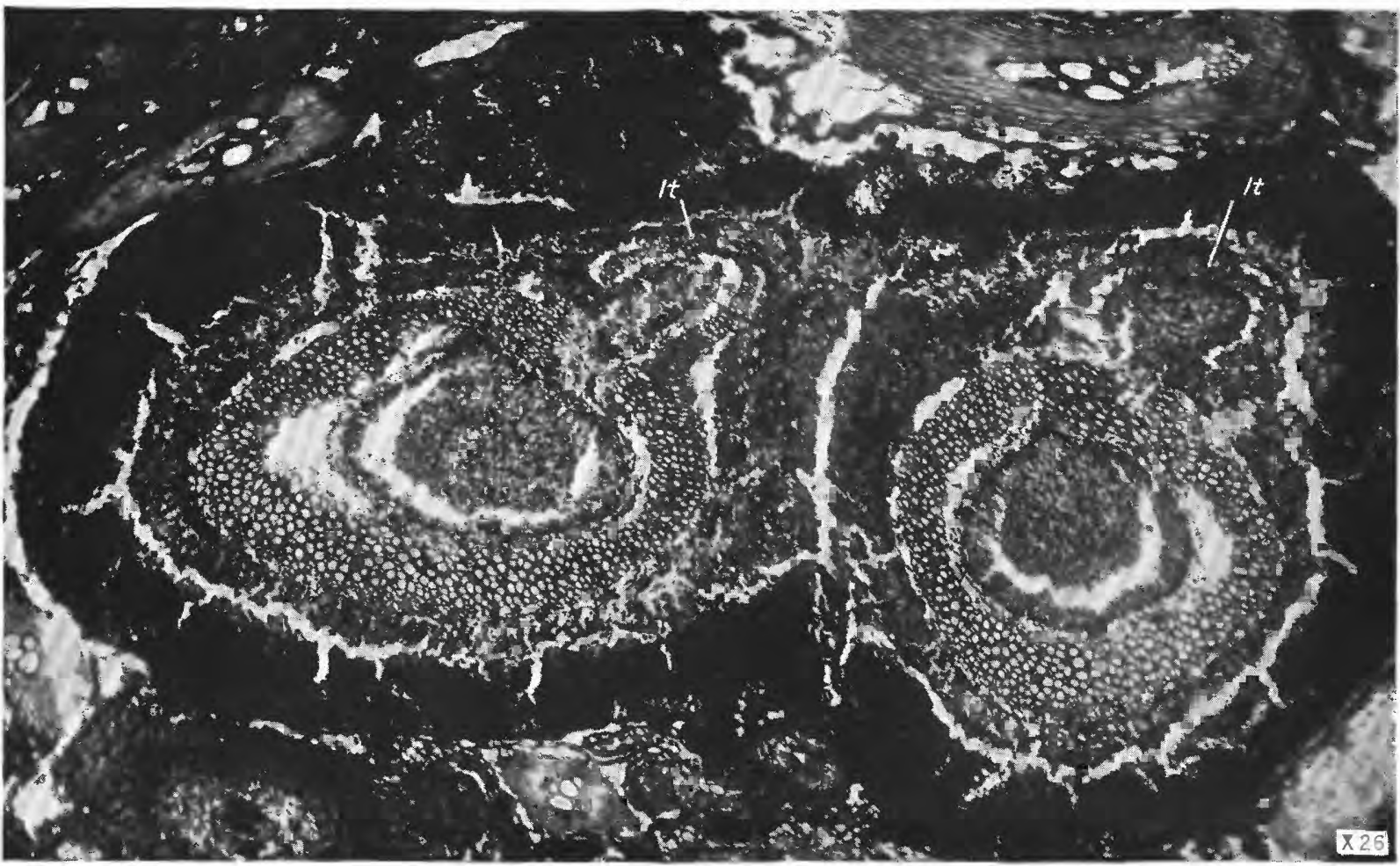

2

AMERICAN CRETACEOUS FERNS OF THE GENUS TEMPSKYA.

1. Transverse section of a stem of Tempskya knowltoni showing an early stage in the emergence of a leaf trace $(l t)$. 2. Dichotomously branching stem of Tempskya knowltoni (leaf traces, $i$ ). 


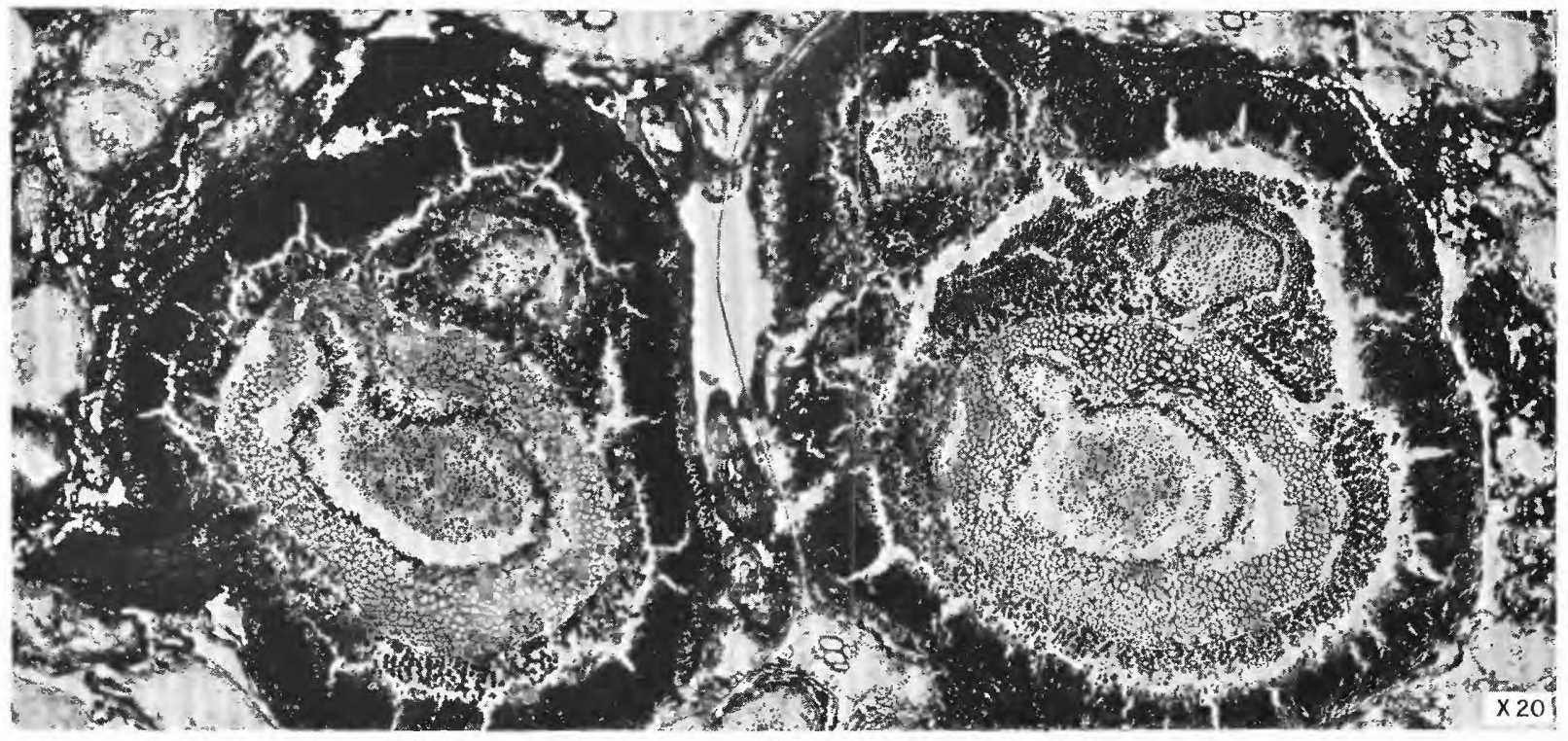

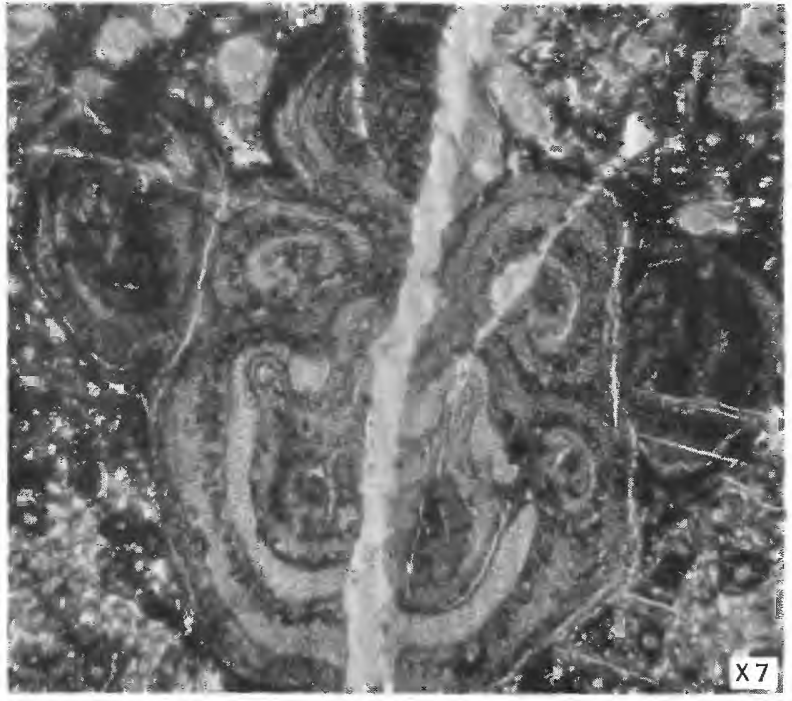

2

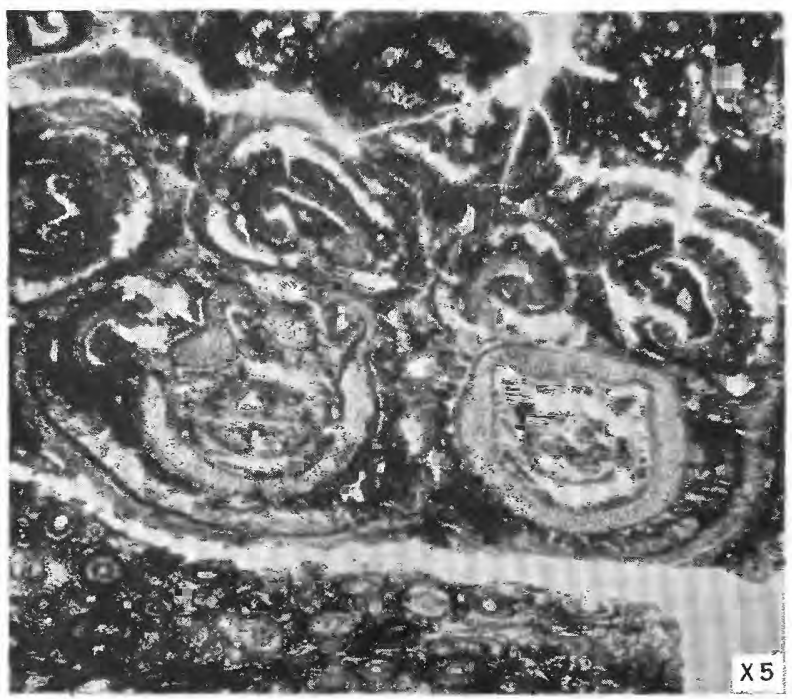

4

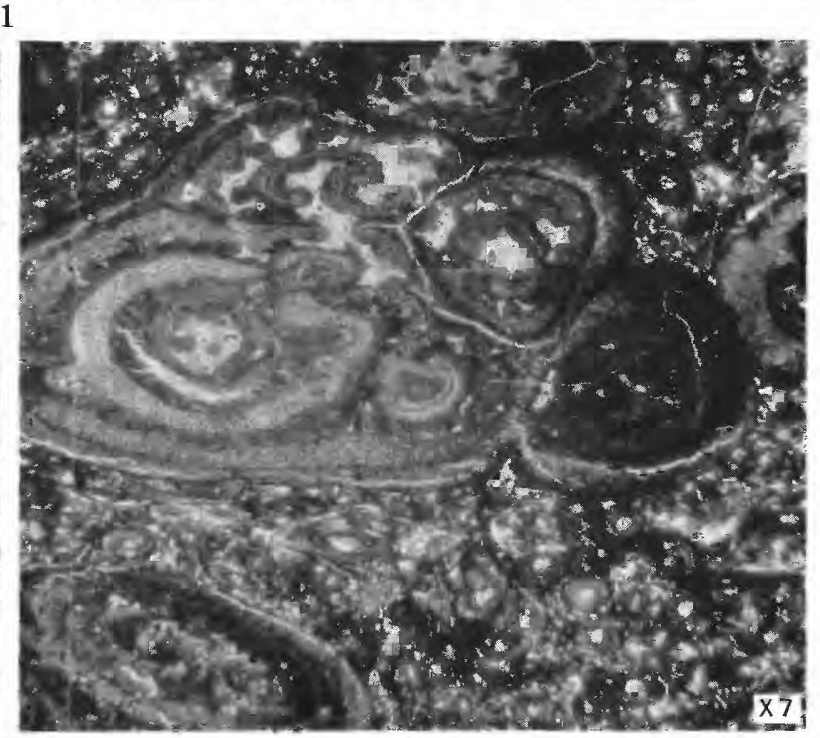

3

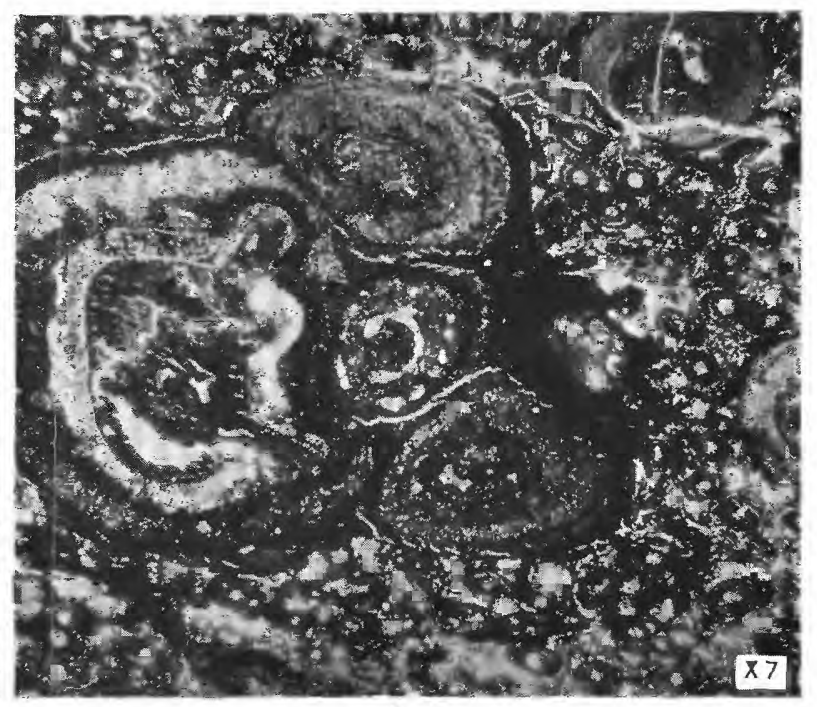

5

AMERICAN CRETACEOUS FERNS OF THE GENUS TEMPSKYA. 1. Transverse section of a portion of a false stem of Tempskya knowltoni showing two stems just above a dichotomy.
2-5. Transverse sections of stems of Tempskya grandis showing general aspects, Note the dichotomy in figure 4 . 

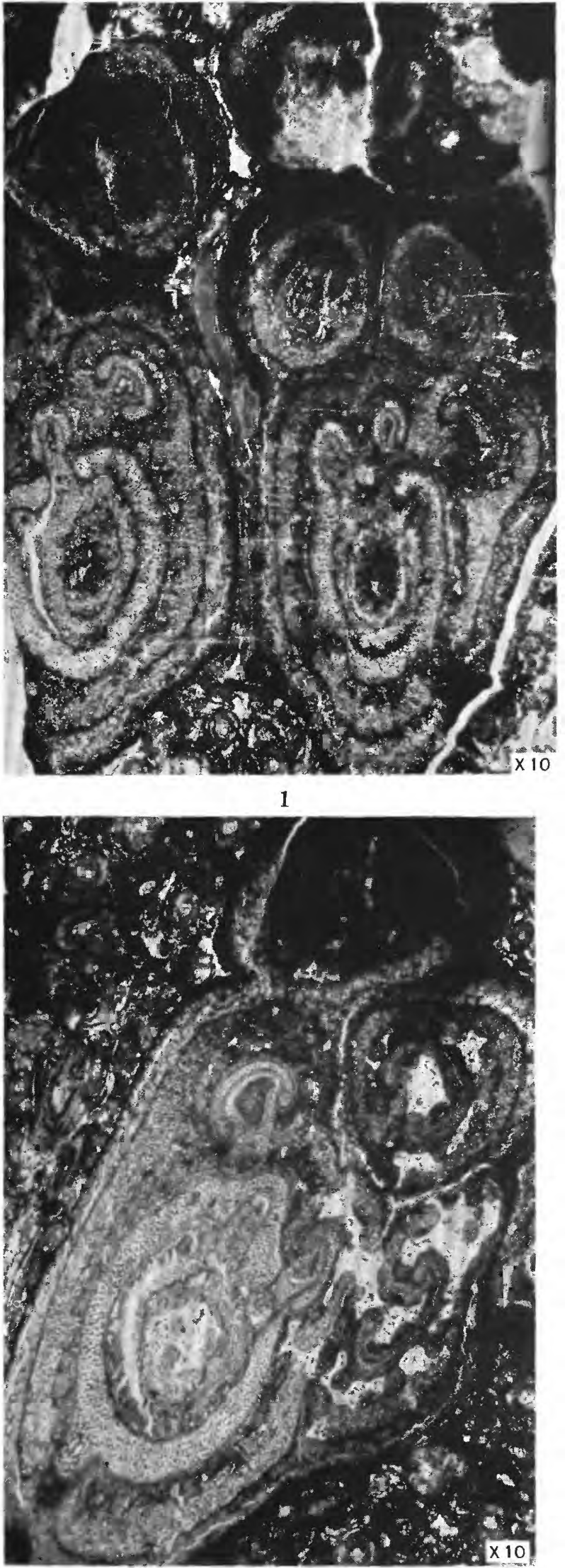

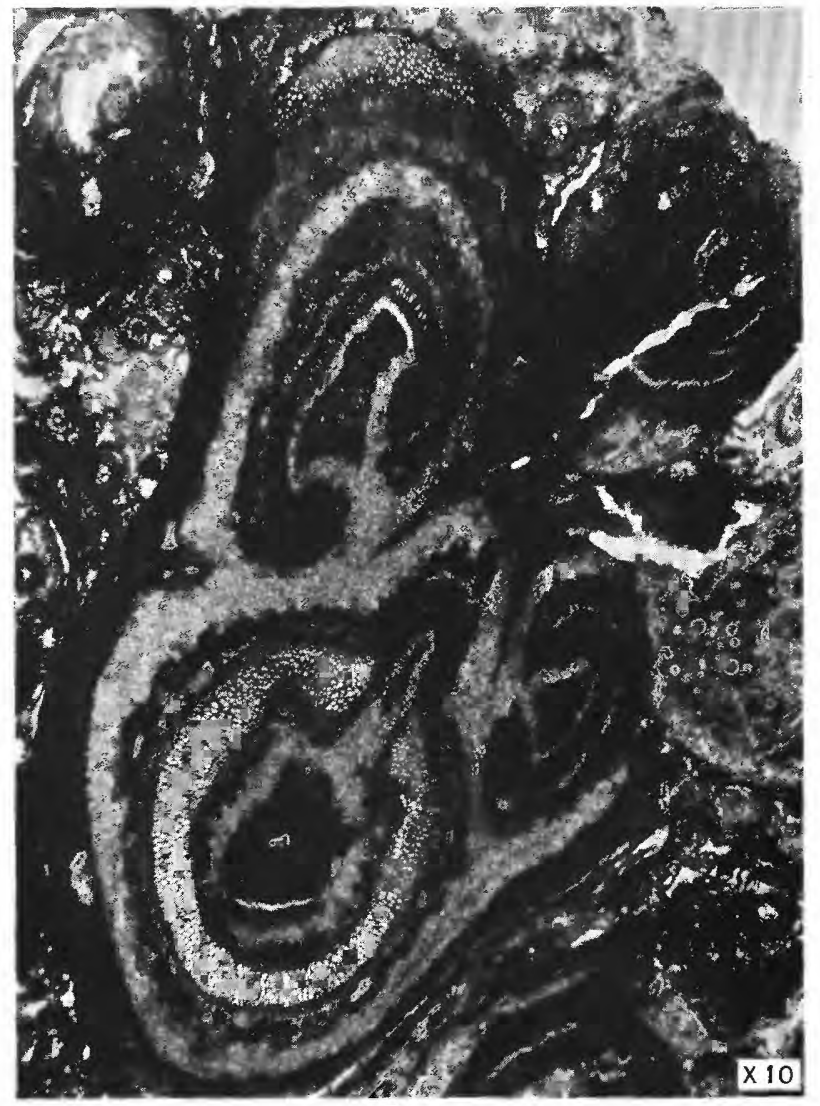

2

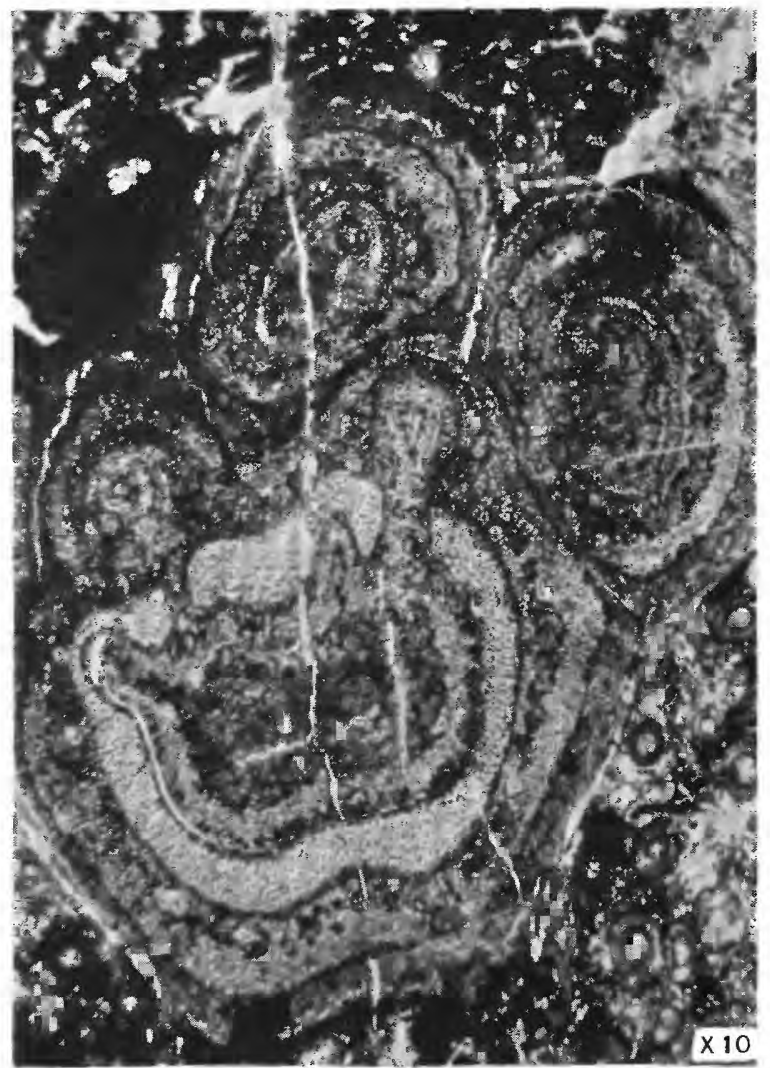

AMERICAN CRETACEOUS FERNS OF THE GENUS TEMPSKYA.

1-4. Transverse sections of stems of Tempskya grandis illustrating general characteristics. Note the sclerotic layers shown in the cortex and pith of the stem shown in figure 2 . 

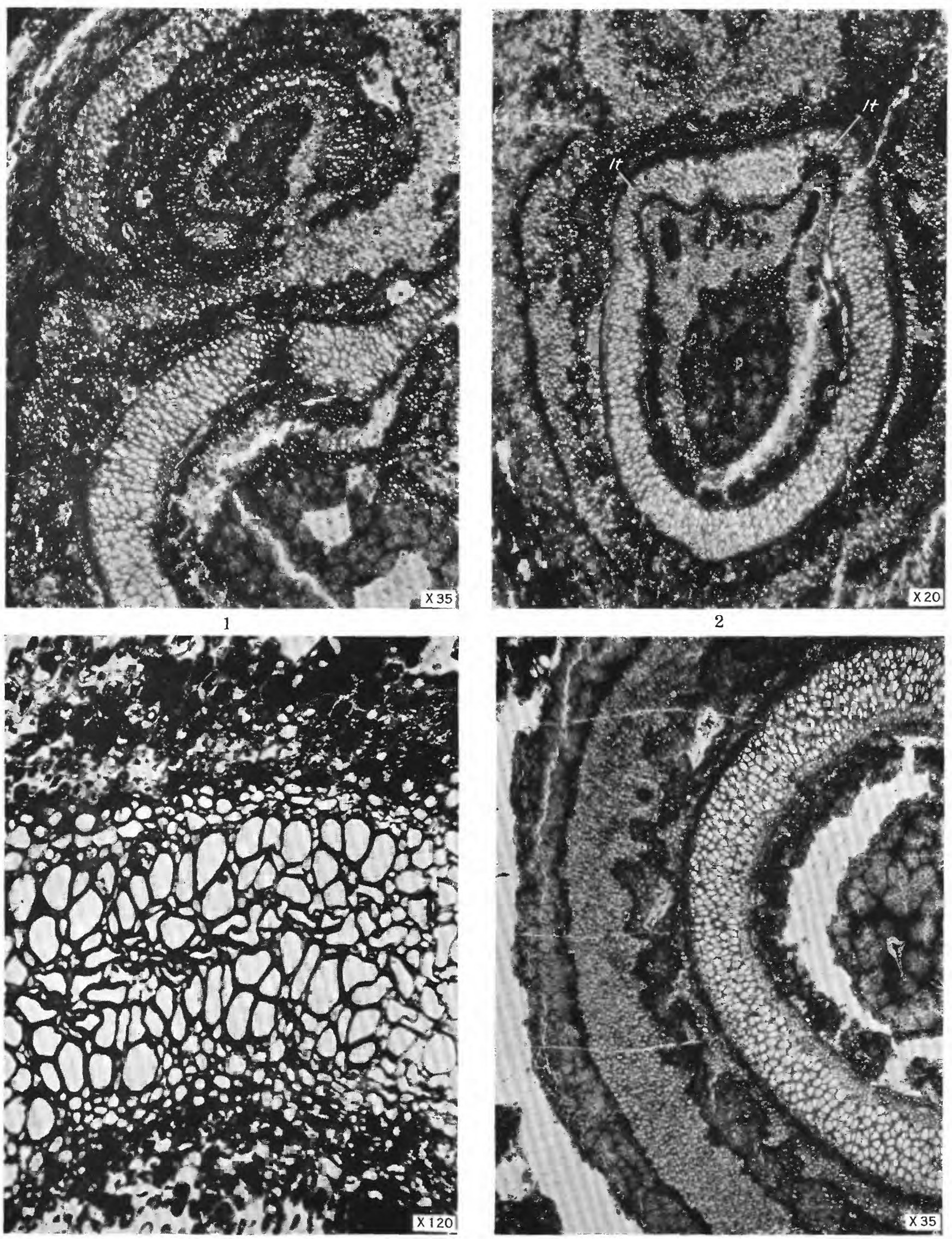

AMERICAN CRETACEOUS FERNS OF THE GENUS TEMPSKYA.

1. Portion of a stem of Tempskya grandis showing an emerging leaf trace. 

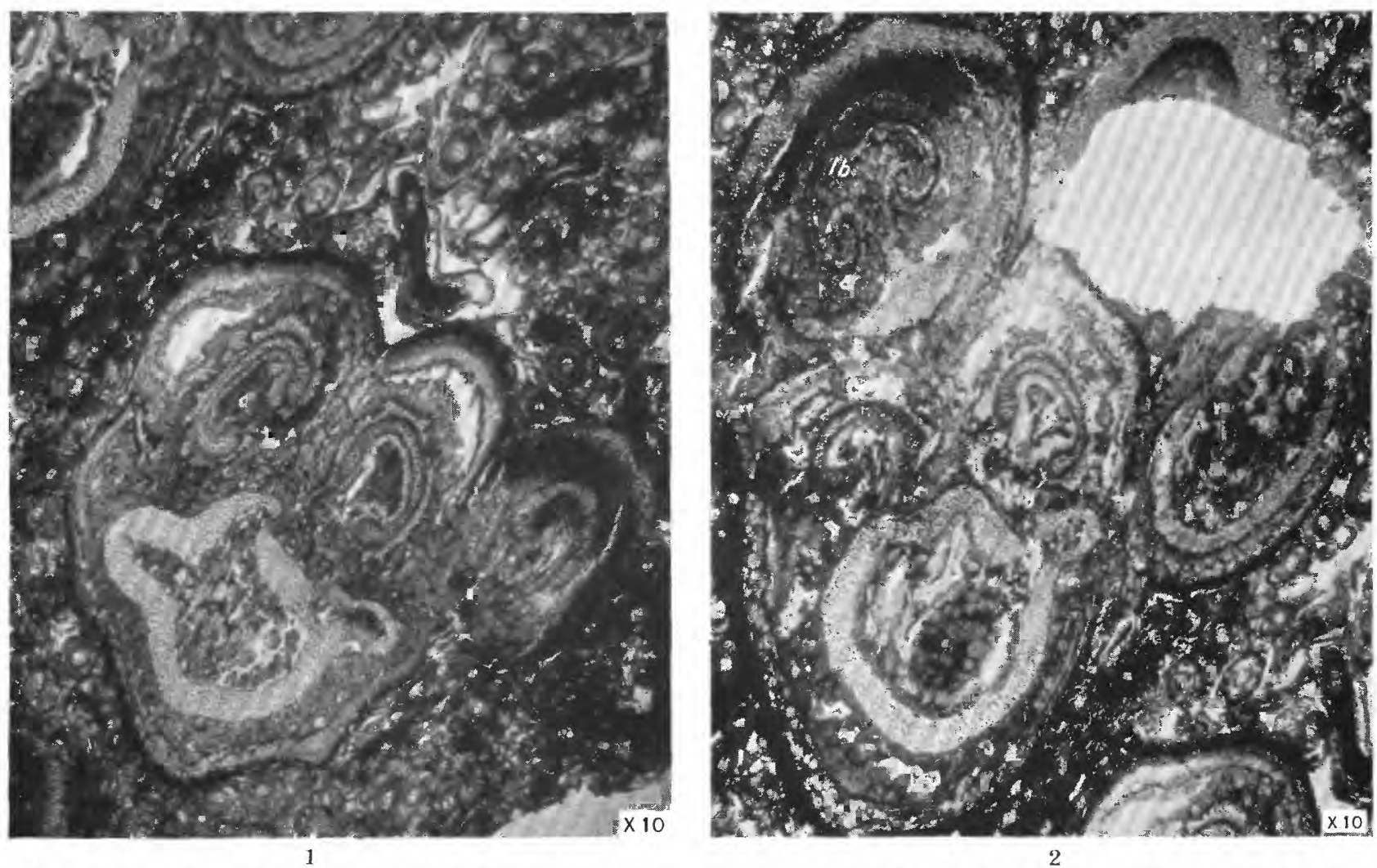

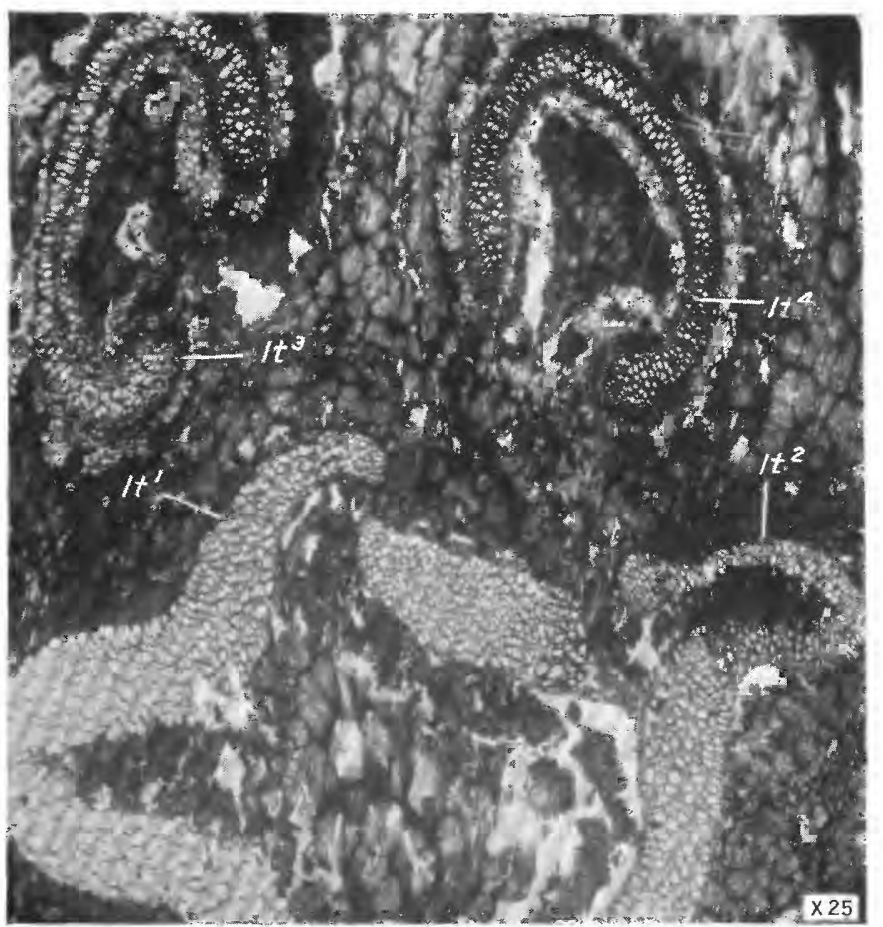

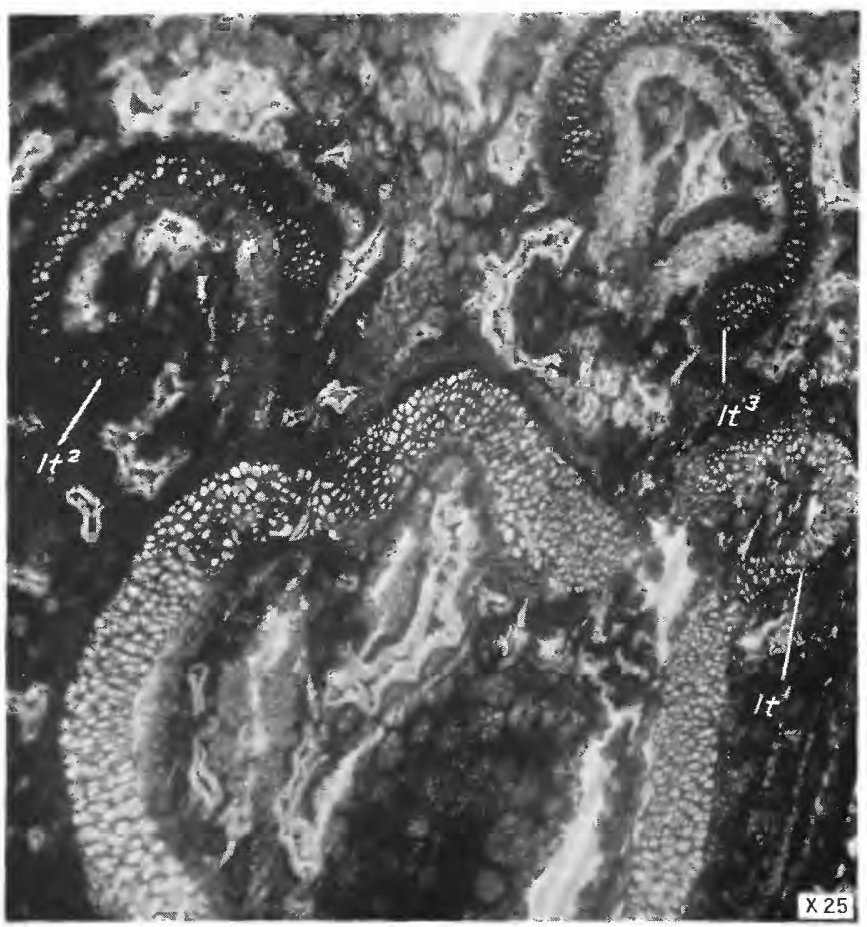

AMERICAN CRETACEOUS FERNS OF THE GENUS TEMPSKYA.

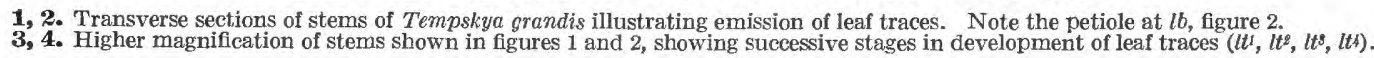




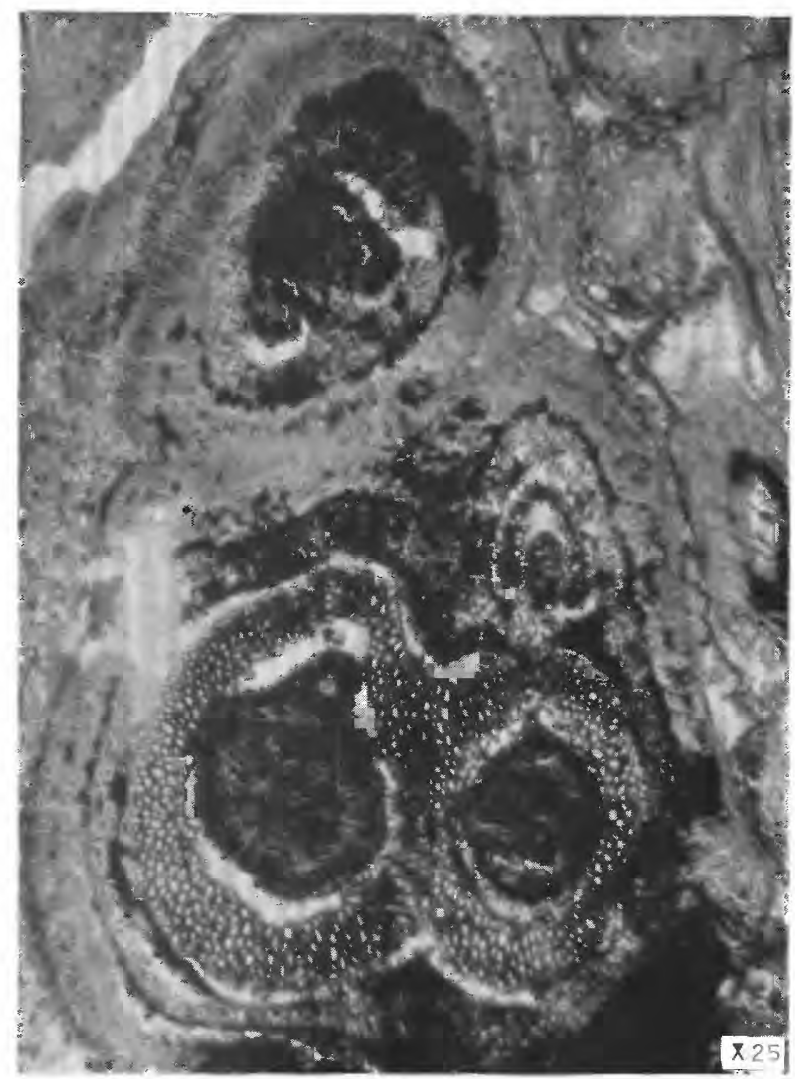

1

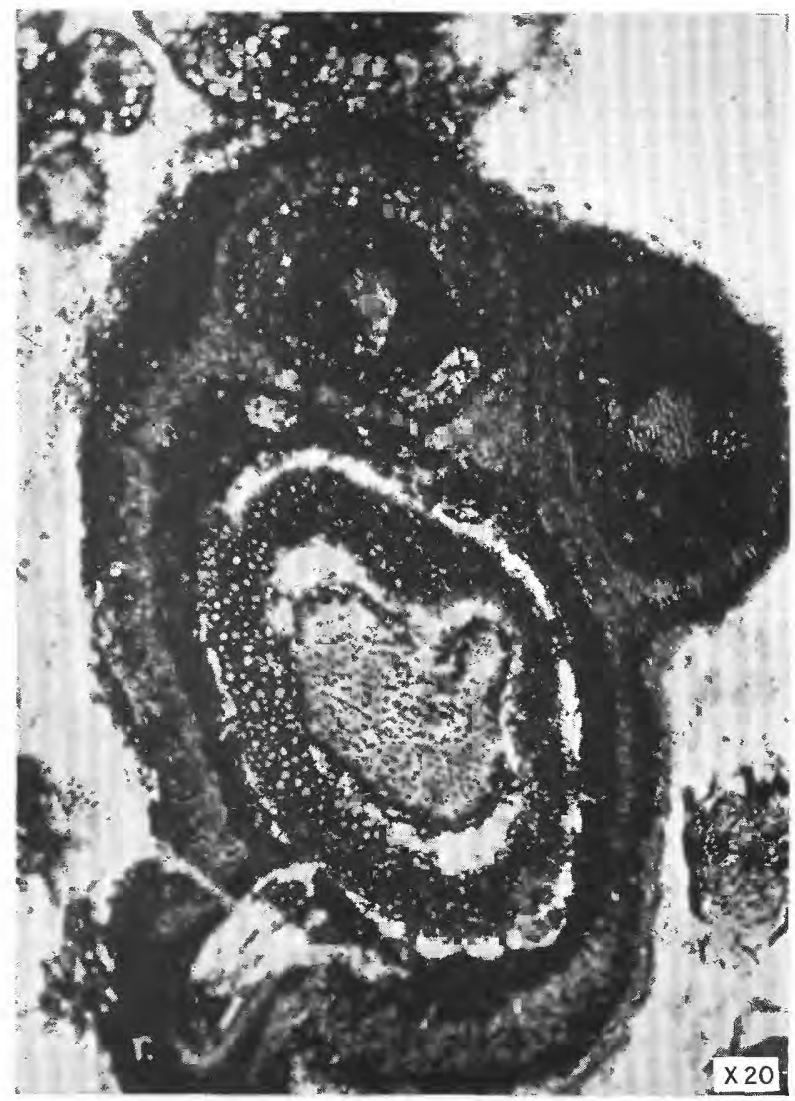

3
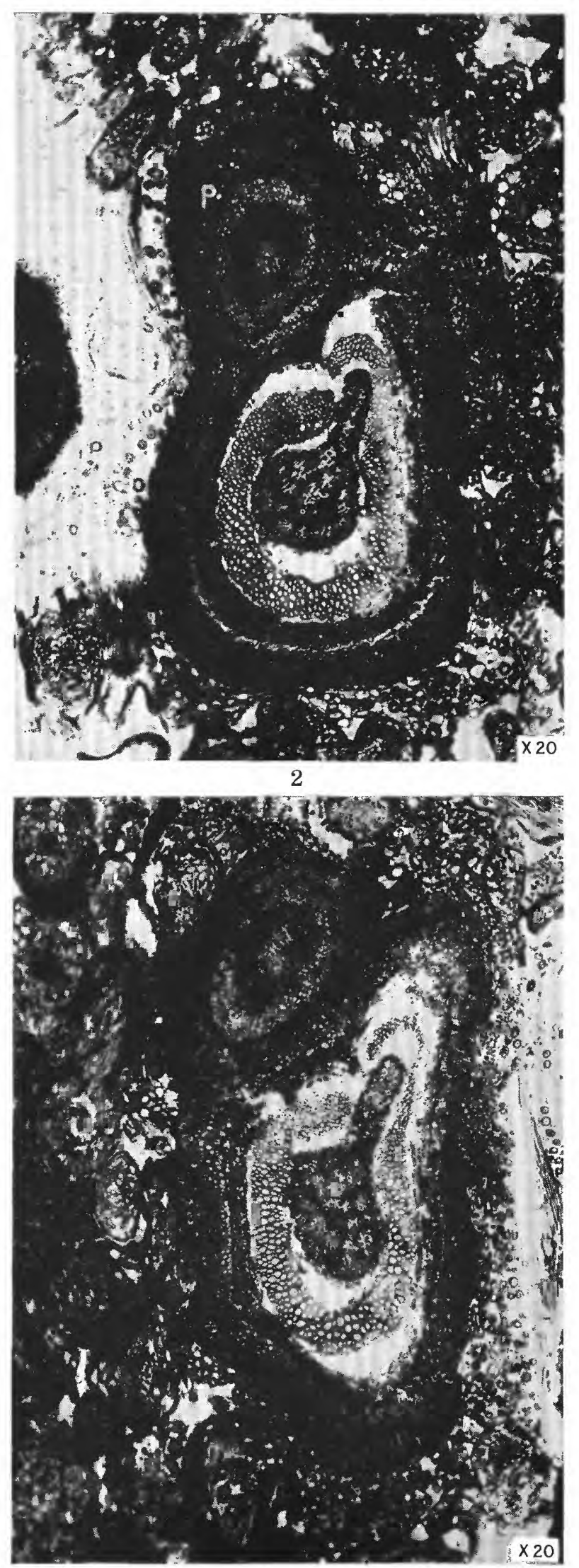

4

AMERICAN CRETACEOUS FERNS OF THE GENUS TEMPSKYA.

1-4. Transverse sections of Tempskya minor illustrating their general aspect. Note the dermal emergences (simple hairs) shown in figures 2 and 4. $p$, Leaf base; $r$, root insertion. 

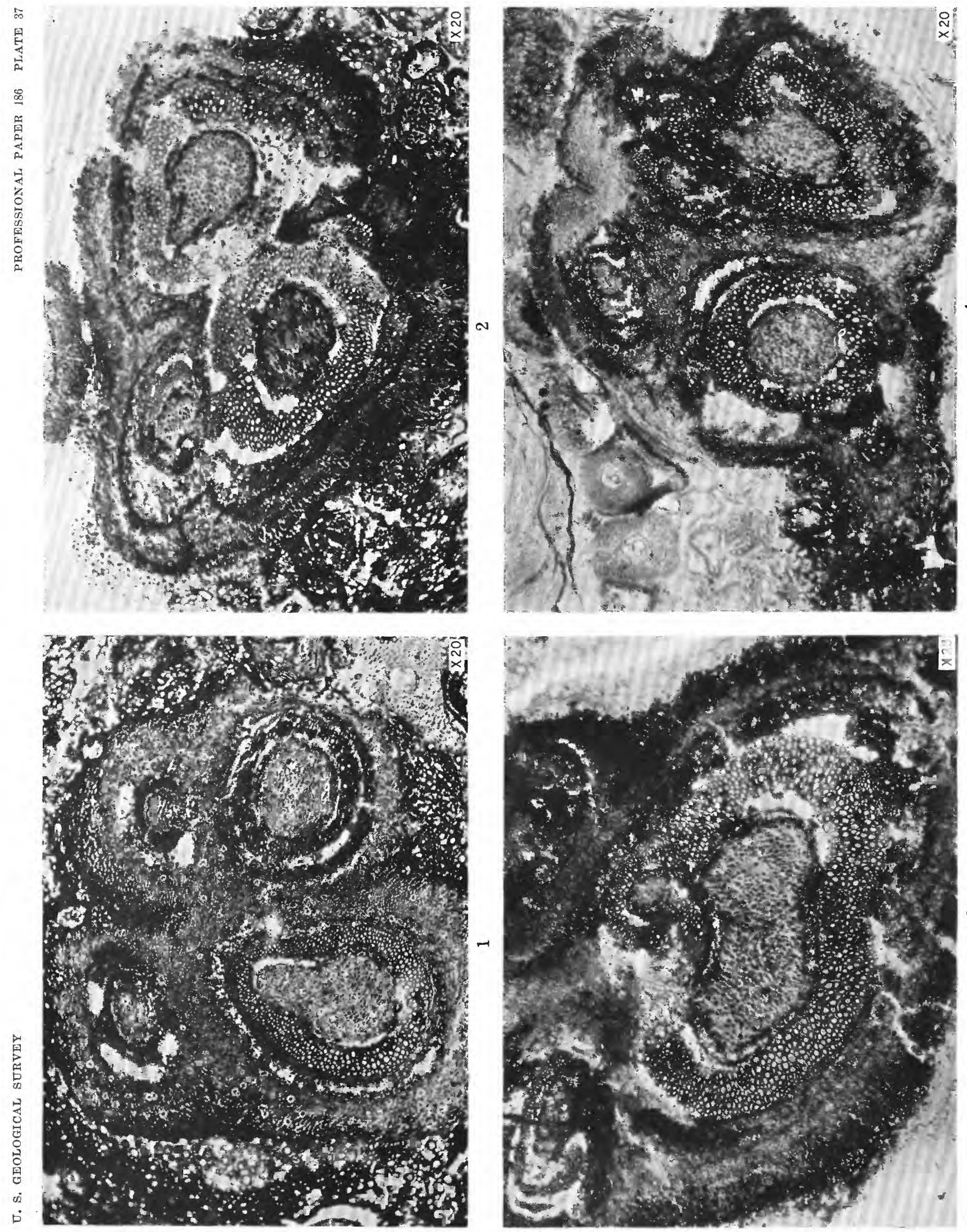

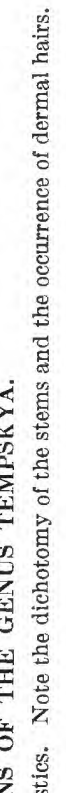

空 


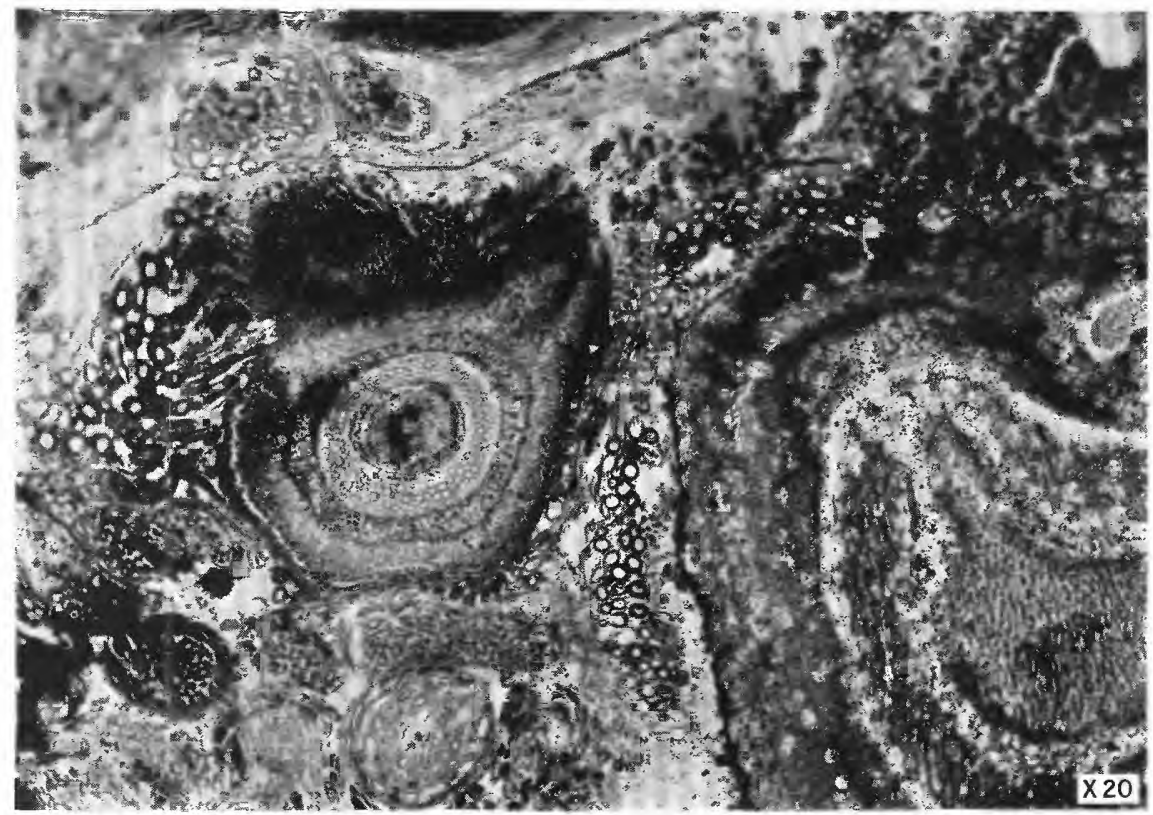

\section{1}

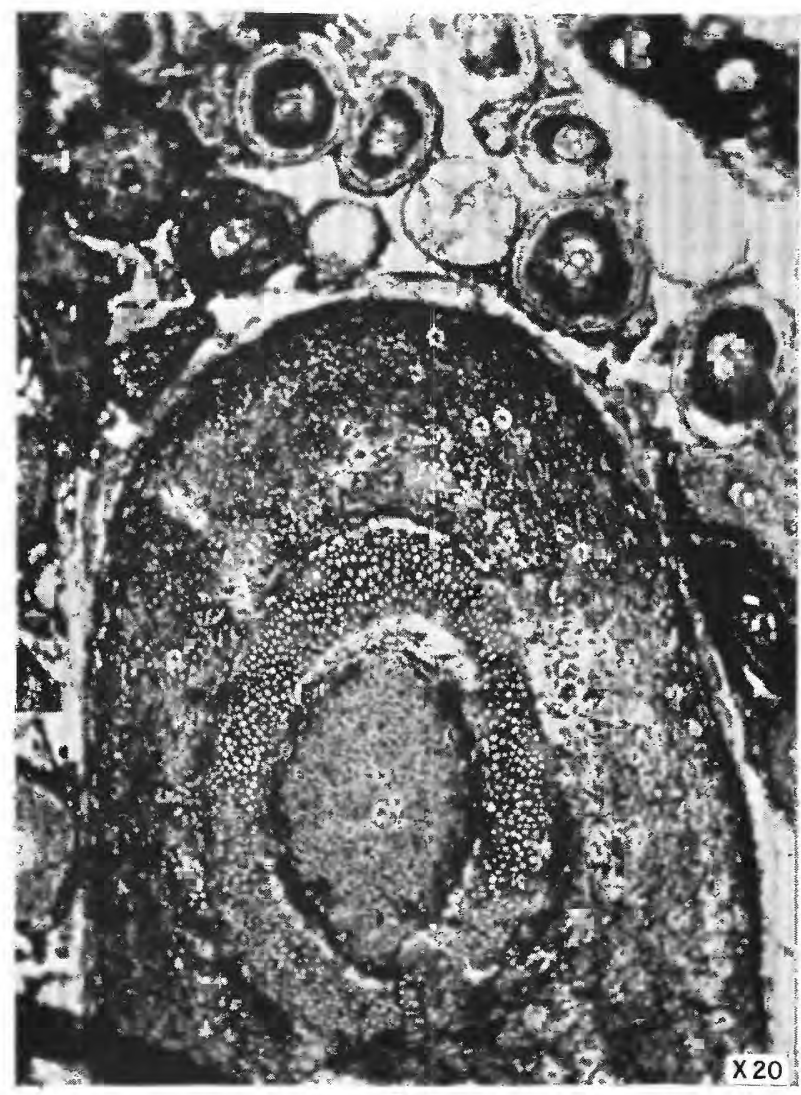

2

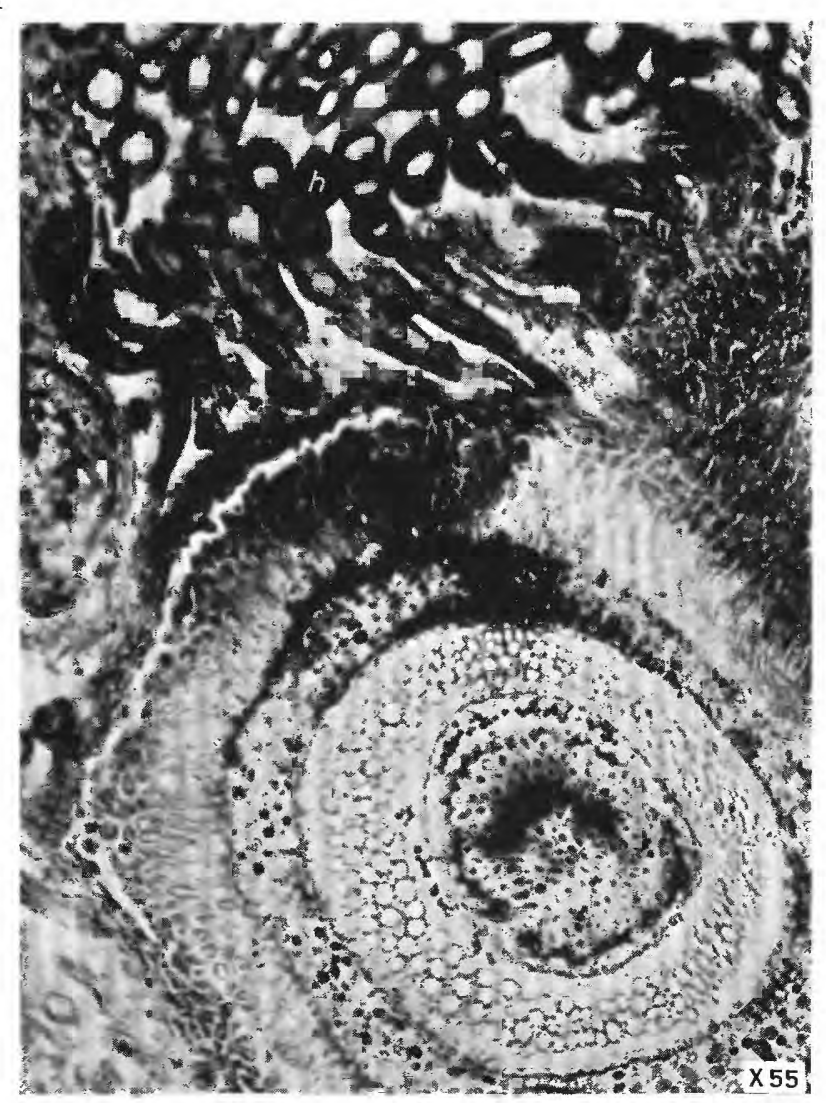

3

AMERICAN CRETACEOUS FERNS OF THE GENUS TEMPSKYA.

1. Section of the stem of Tempskya minor showing the abundant epidermal hairs, apparently most nimerous on the upper surface of the stem in the vicinity of the leaf bases.

3. Section of the stem of Tempskya minor showing the uninterrupted xylem cylinder at an internode. 


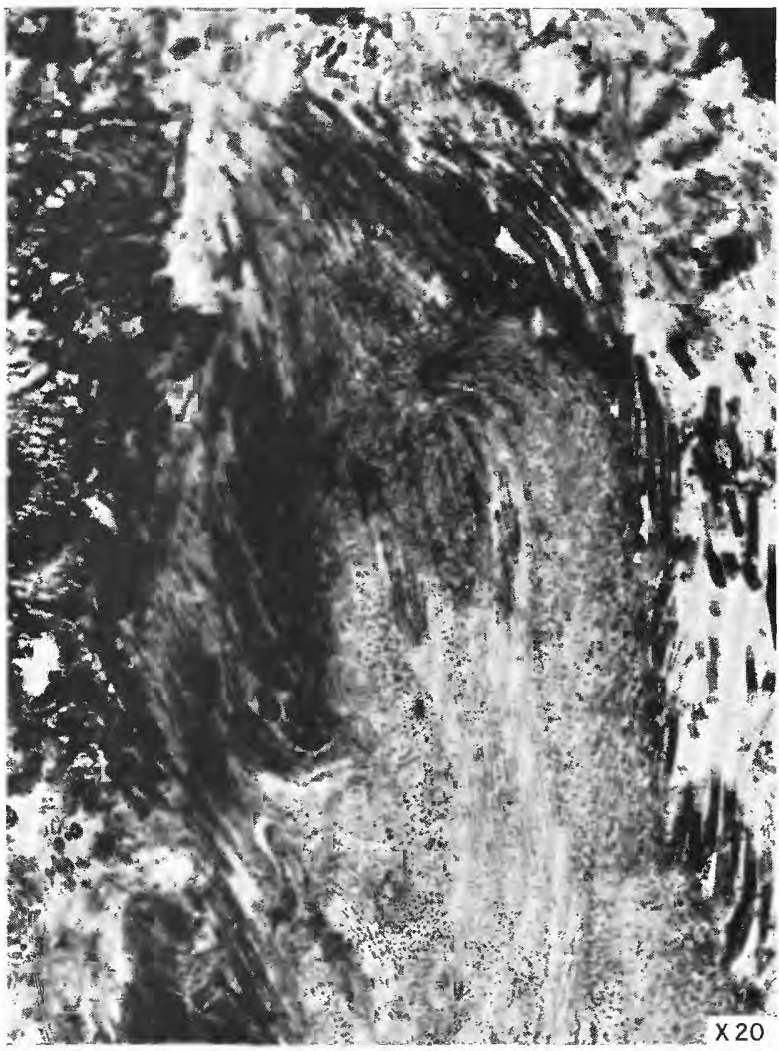

1

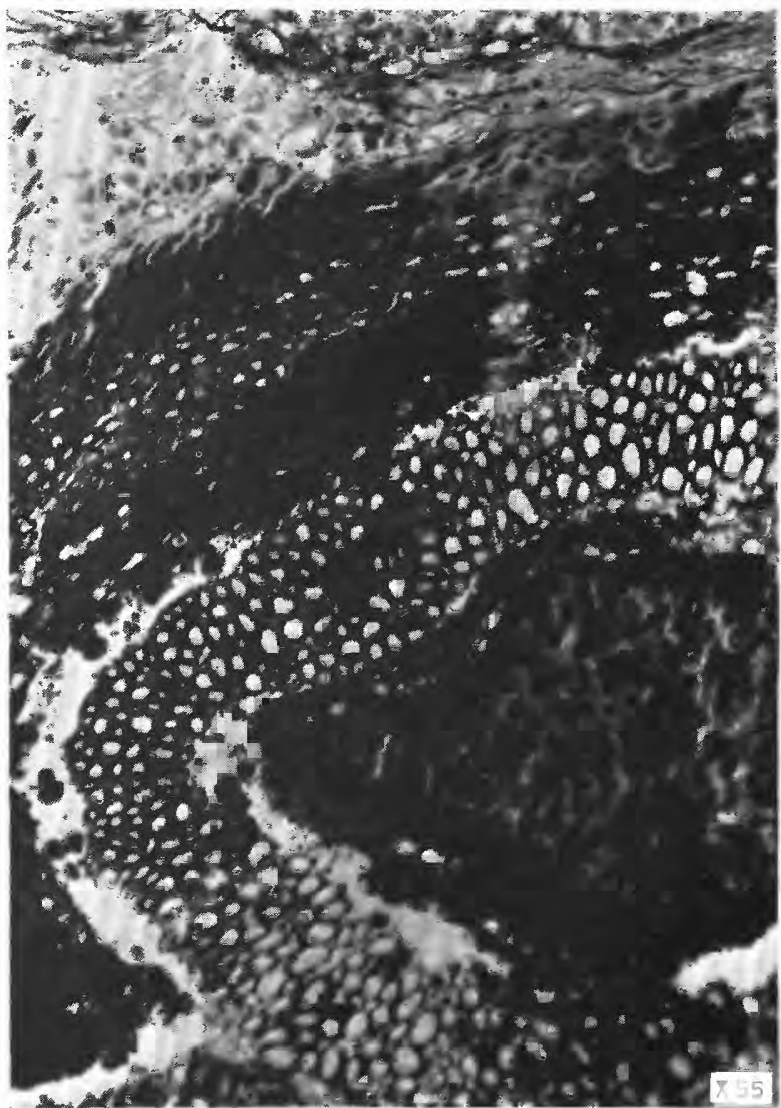

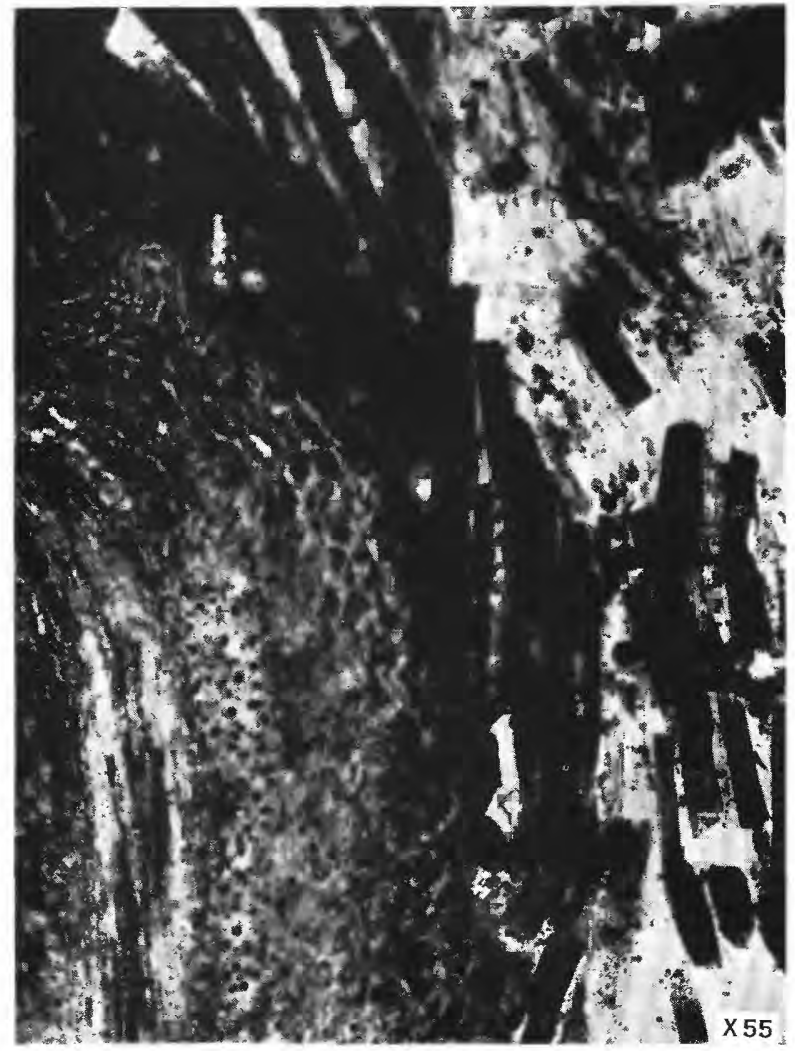

2

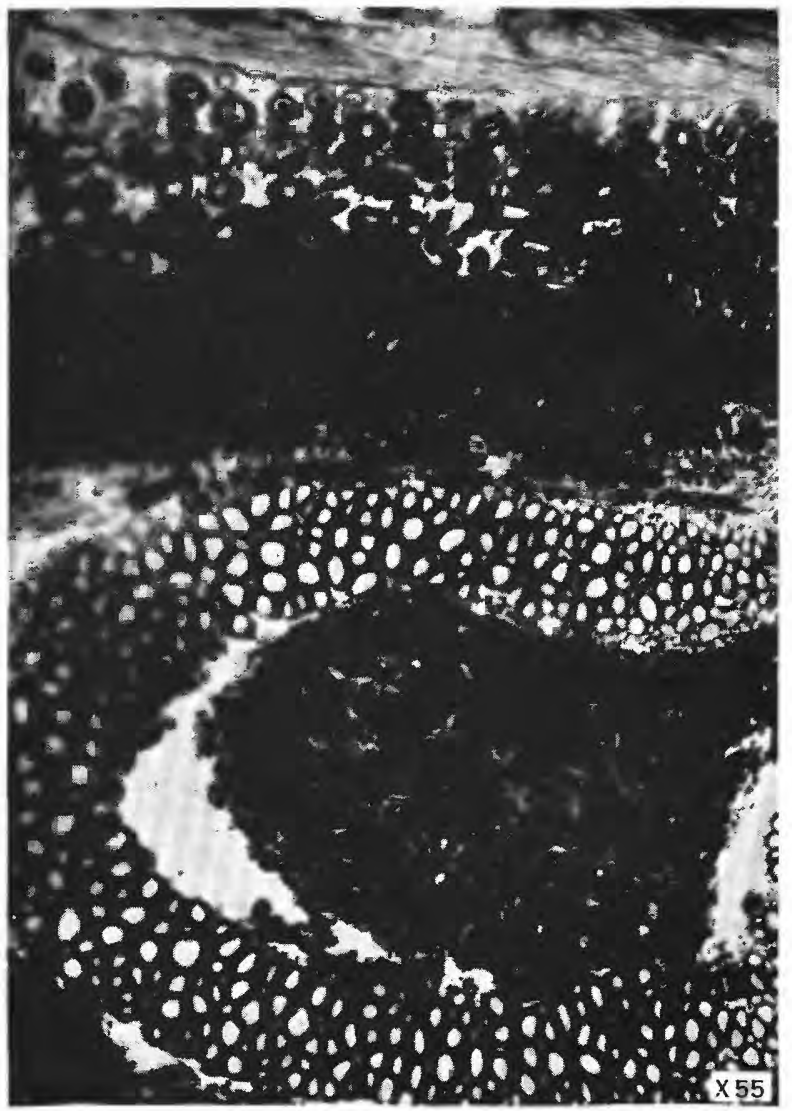

AMERICAN CRETACEOUS FERNS OF THE GENUS TEMPSKYA.

1. Longitudinal section of a stem of Tempskya minor cut near the apex, showing the investing epidermal hairs. 1. Portion of the section shown in figure 1 taken at a higher magnification to show details of the hairs. 3, 4. Transverse sections of stem of Tempskya minor showing the epidermal emergences. 

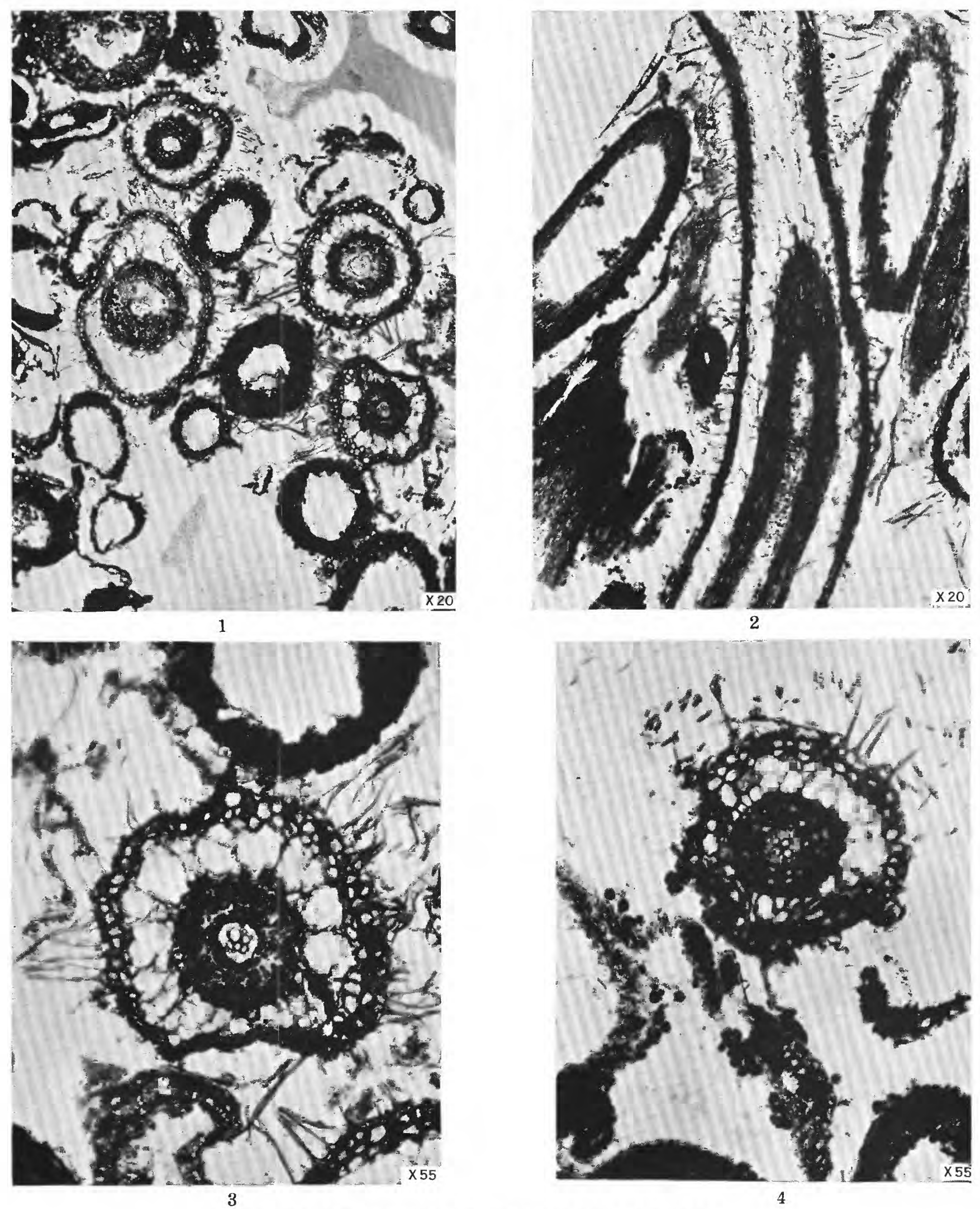

AMERICAN CRETACEOUS FERNS OF THE GENUS TEMPSKYA.

1. Transverse sections of roots with attached root hairs in Tempskya minor. Note the lacunar zone in the outer cortex.

3, 4. Transverse sections of roots showing details of structure and attachment of root hairs. 

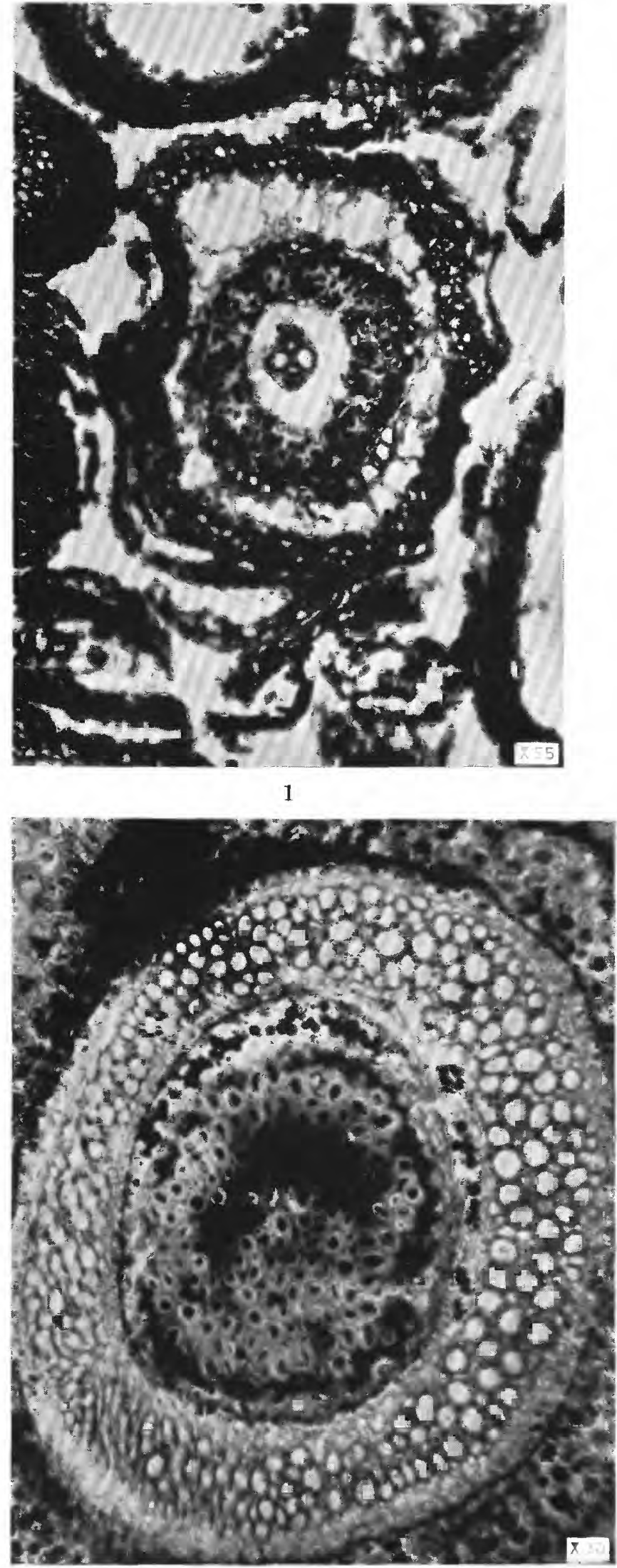

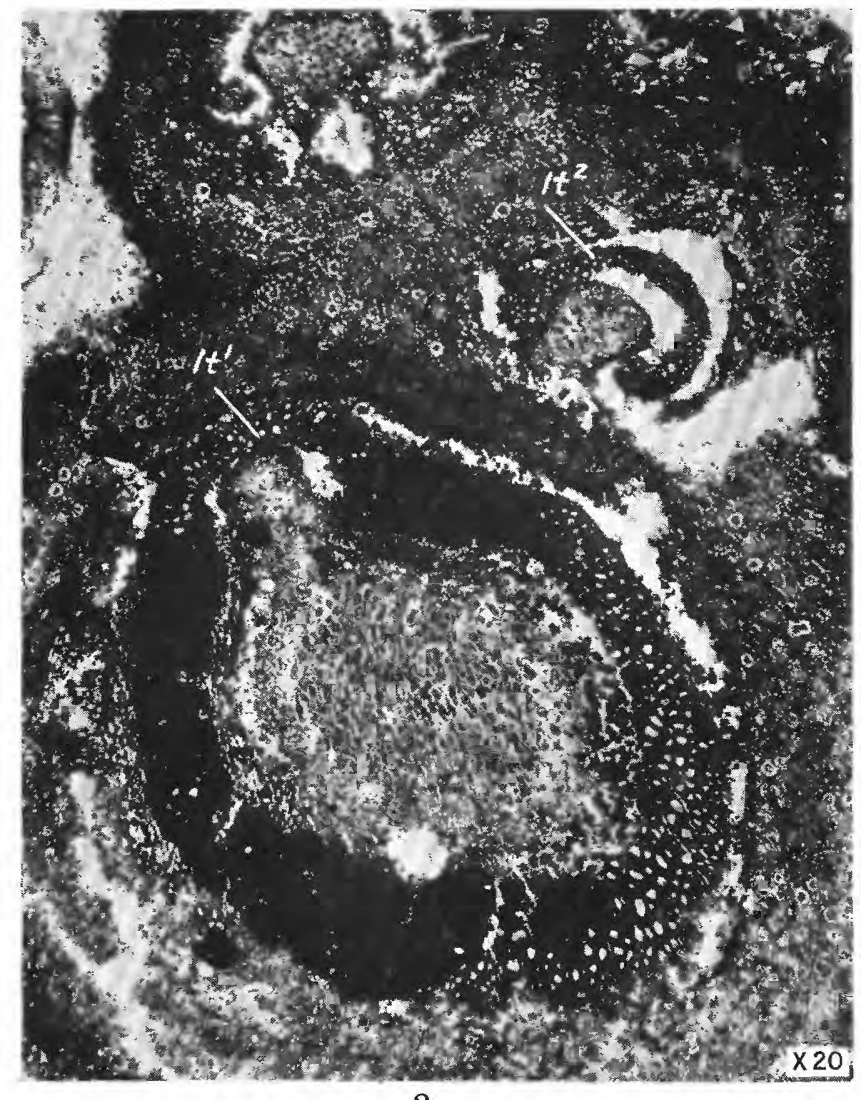

2

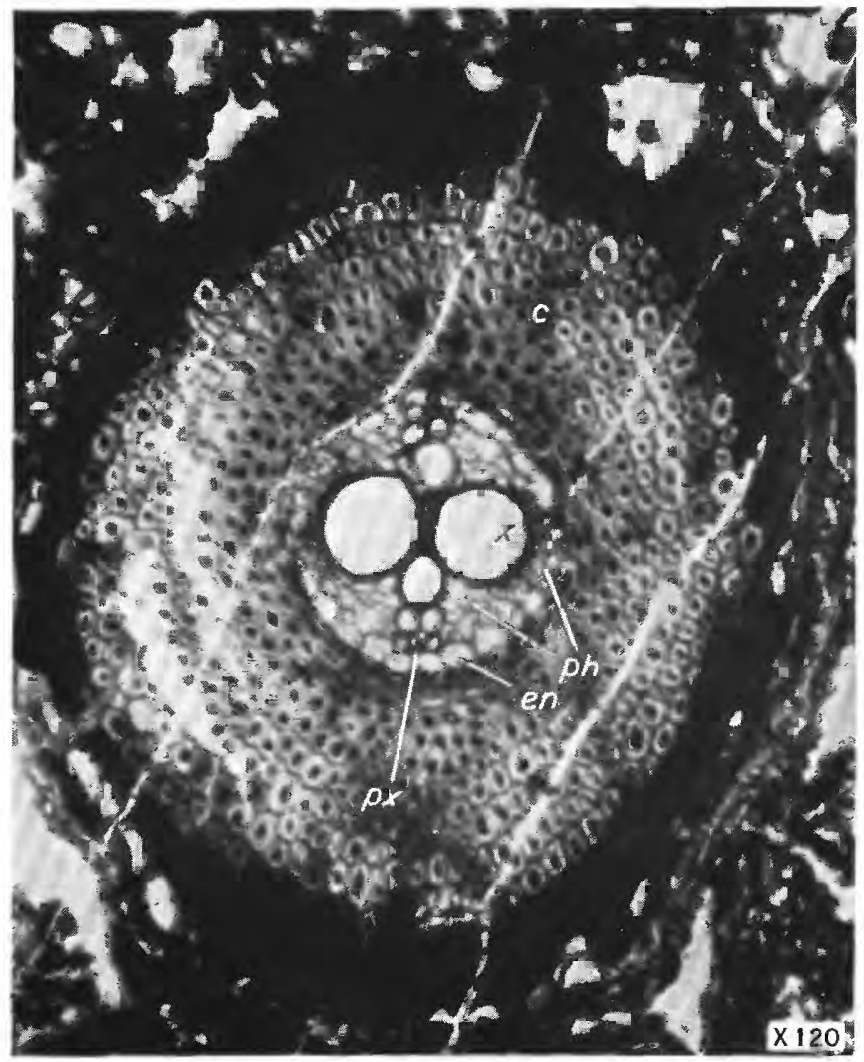

4

AMERICAN CRETACEOUS FERNS OF THE GENUS TEMPSKYA.

1. Root of Tempskya minor showing lacunar cortex.

2. Stem of Tempskya minor showing leaf traces, it 1 it $^{2}$, it ${ }^{3}$

3. Transverse section of the vascular cylinder of Tempskya minor showing details of structure. Note the suggestion of a long internode indicated by the absence of any

4. Transverse section of a root of Tempskya grandis showing details of morphology. px, Protoxylem; $x$, xylem; ph, phloem; en, endodermis; $c$, cortex. 


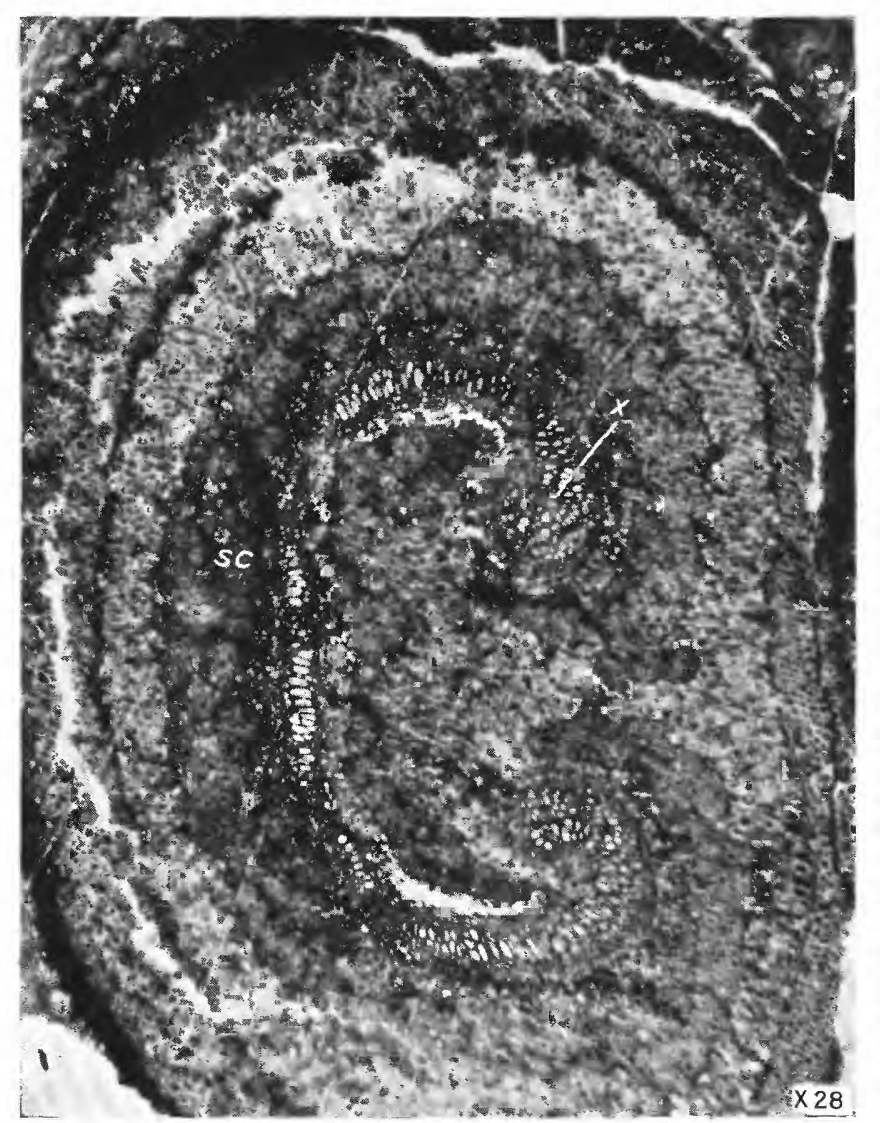

1

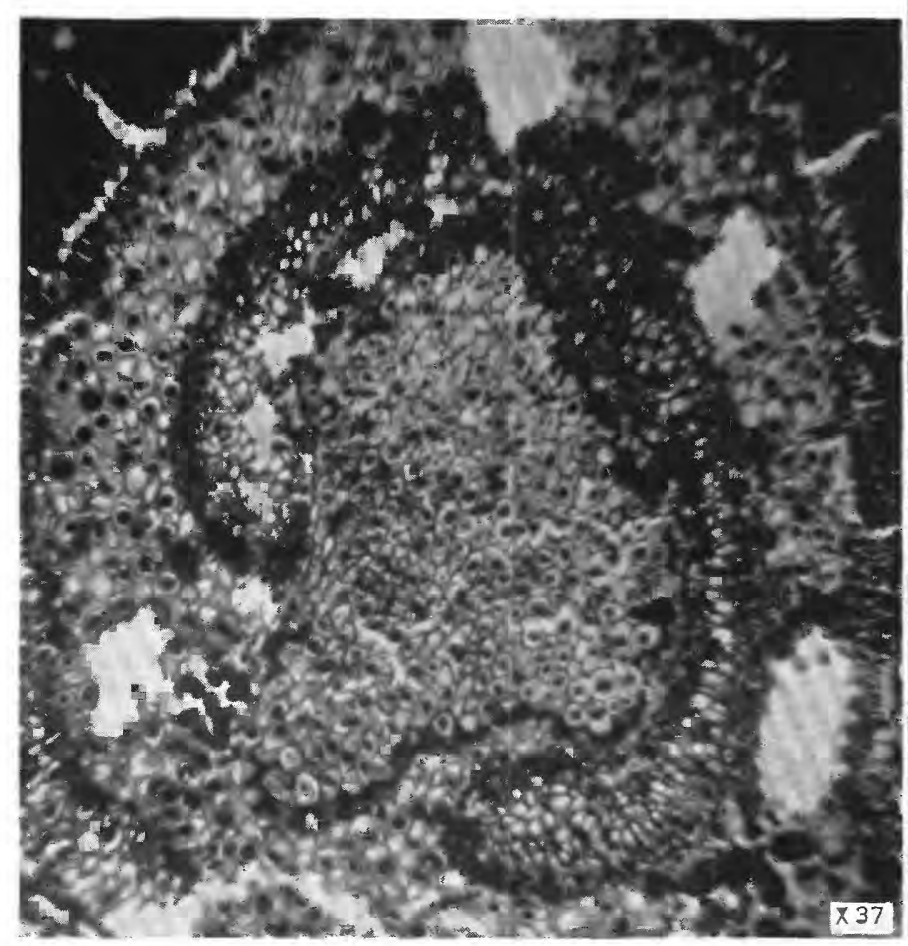

4
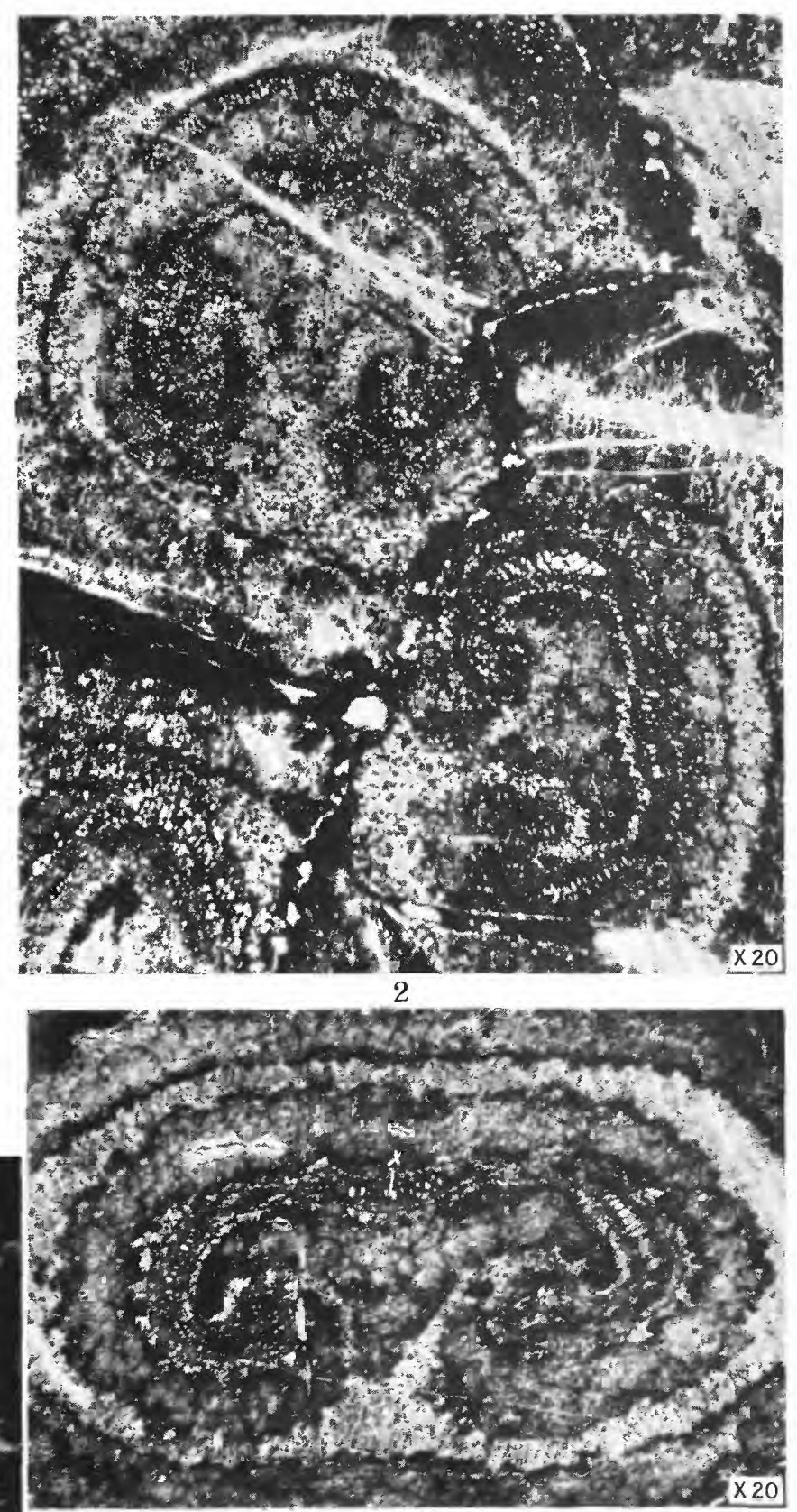

3

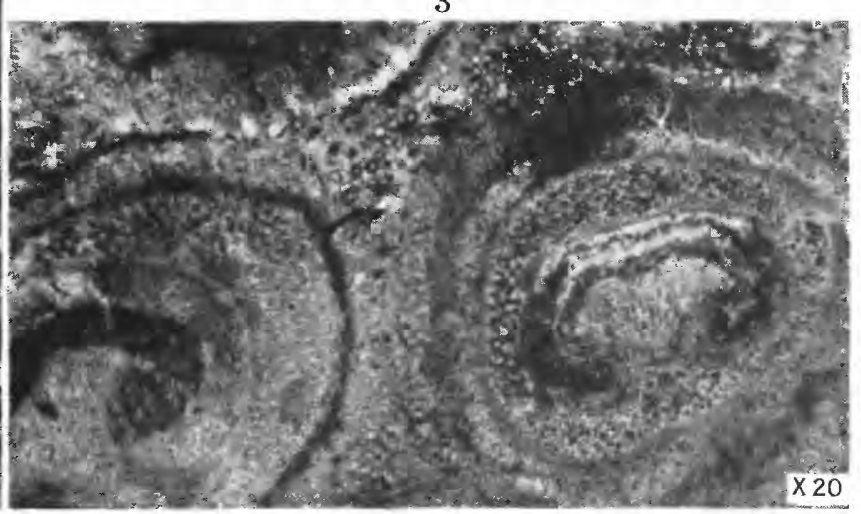

5

AMERICAN CRETACEOUS FERNS OF THE GENUS TEMPSKYA.

1-3. Leaf bases of Tempskya grandis showing characteristic morphology. $x$, Xylem.

5. Leaf bases of Tempskya minor showing general features. Note the investing hairs. 

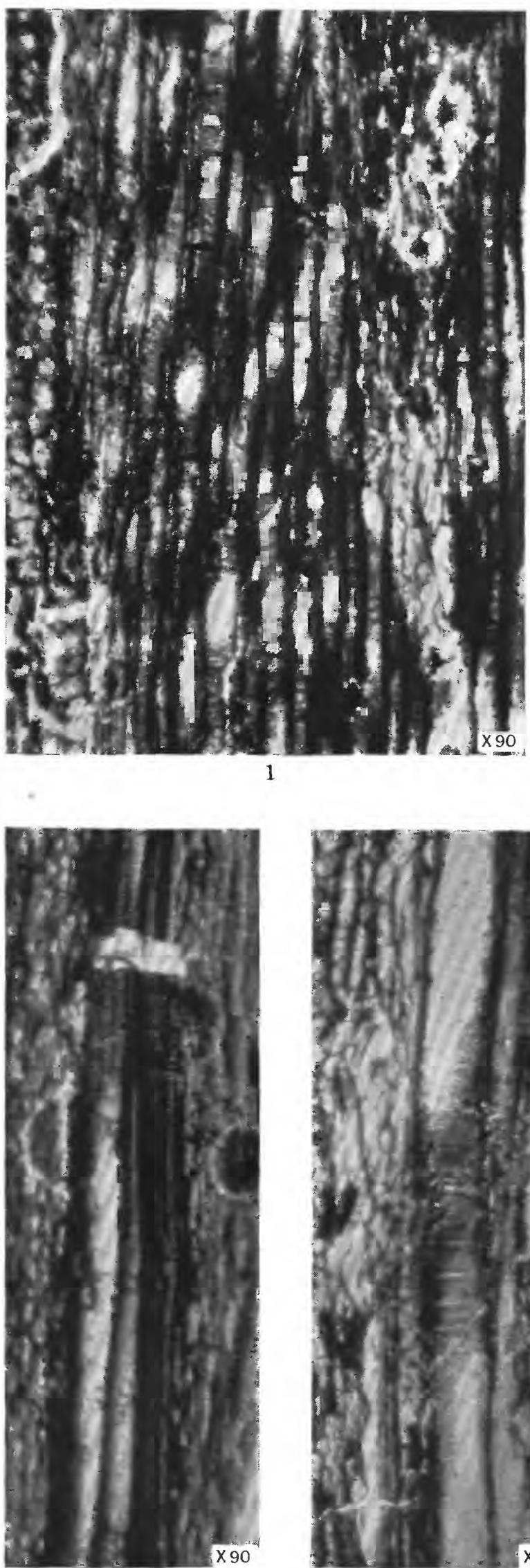

4

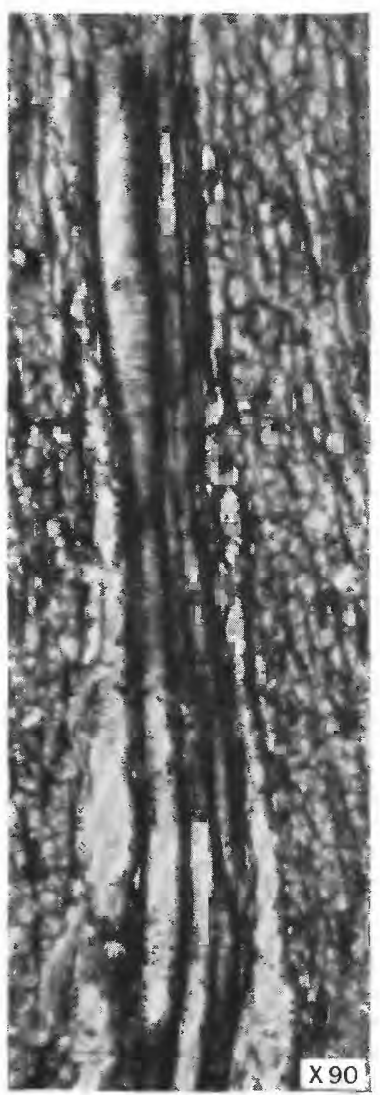

2

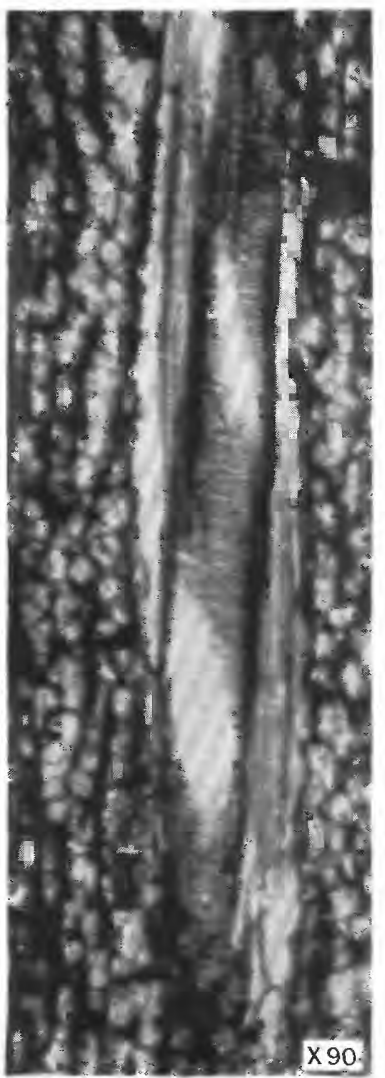

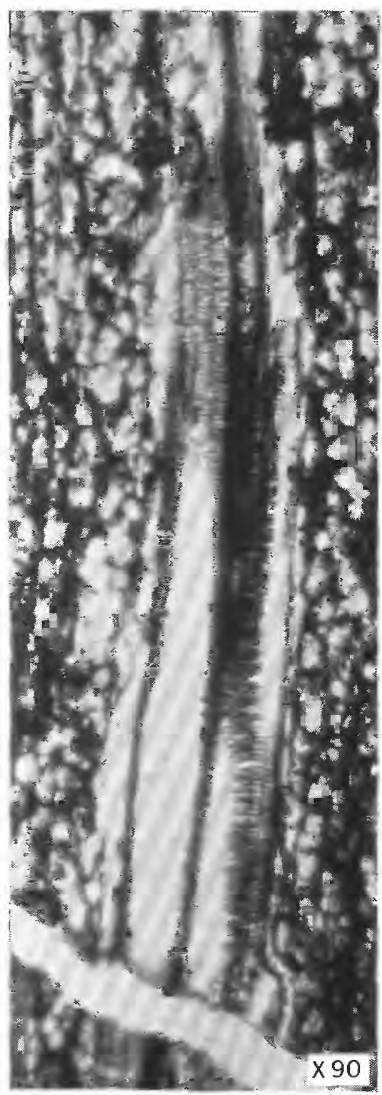

3

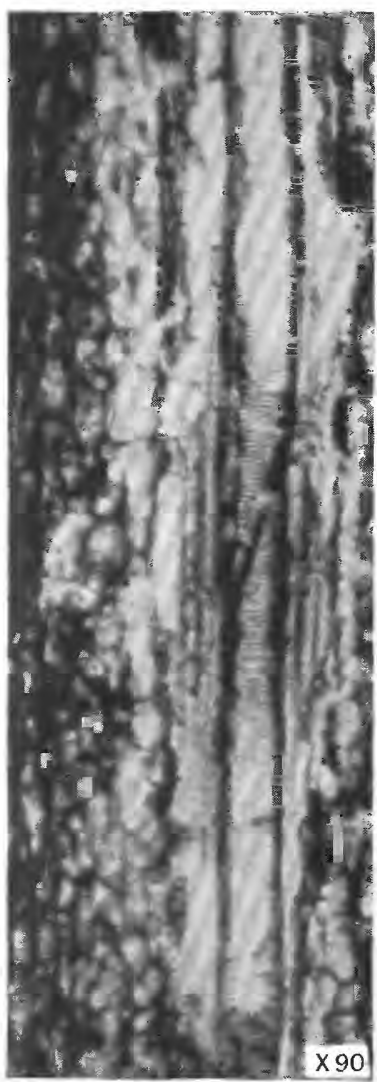

7

AMERICAN CRETACEOUS FERNS OF THE GENUS TEMPSKYA.

1. Longitudinal section of the stem of Tempskya grandis showing the scalariform tracheids.

and showing the scalariform tracheids. 3-\%. Longitudinal sections of roots of Tempskya knowltoni (fig. 3) and Tempskya grandis (figs. 4-7) showing xylem and adjacent tissues. 